NBER WORKING PAPER SERIES

\title{
THE IMPACT OF THE WWI AGRICULTURAL BOOM AND BUST ON FEMALE OPPORTUNITY COST AND FERTILITY
}

\author{
Luke P. Rodgers \\ Carl \\ $\mathrm{T}$. \\ Working Paper 27530 \\ http://www.nber.org/papers/w27530 \\ NATIONAL BUREAU OF ECONOMIC RESEARCH \\ 1050 Massachusetts Avenue \\ Cambridge, MA 02138 \\ July 2020, Revised October 2022
}

Kitchens

We would like to thank Rachel Johnson, Ian Linares, Melissa Pregason, Marco Taylhardat, Justin Bailey, and Anthony Manucci for data entry assistance. We would also like to thank Martin Fiszbein, James Feigenbaum, Carolyn Moehling, Melissa Thomasson, and Lauren Hoehn Velasco for making data available. We thank E. Jason Baron, Brian Beach, Briggs Depew, Ezra Goldstein, Alex Hollingsworth, Matt Jaremski, Taylor Jaworski, Shawn Kantor, Paul Rhode, Nicolas Ziebarth and seminar participants at 2019 WATE, 2020 EHA Meetings, 2020 SEA meetings, 2021 AEA Meetings, 2021 NBER DAE Spring Meeting, Florida State University, and Vanderbilt for helpful feedback. Finally, any errors contained within are our own. The views expressed herein are those of the authors and do not necessarily reflect the views of the National Bureau of Economic Research.

NBER working papers are circulated for discussion and comment purposes. They have not been peer-reviewed or been subject to the review by the NBER Board of Directors that accompanies official NBER publications.

(C) 2020 by Carl T. Kitchens and Luke P. Rodgers. All rights reserved. Short sections of text, not to exceed two paragraphs, may be quoted without explicit permission provided that full credit, including $(\odot$ notice, is given to the source. 
The Impact of the WWI Agricultural Boom and Bust on Female Opportunity Cost and Fertility Carl T. Kitchens and Luke P. Rodgers

NBER Working Paper No. 27530

July 2020, Revised October 2022

JEL No. J12,J13,N12,N5

\begin{abstract}
$\underline{\text { ABSTRACT }}$
Using variation in crop prices induced by large swings in demand surrounding World War I, we examine the fertility response to crop revenue increases from 1910 to 1930 . Our estimates from samples utilizing complete count decennial census microdata and newly collected county-level data from state health reports indicate that agricultural price increases reduced fertility, explaining about 9 percent of the overall decline in fertility over the period. The effect persists years after the collapse of the war boom. Importantly, we show that fertility declines were concentrated in women living on the farm and that fertility declined along both the intensive and extensive margins. Combined, the pattern of estimates is consistent with agricultural women experiencing an increase in the opportunity cost of their time.
\end{abstract}

\author{
Carl T. Kitchens \\ Department of Economics \\ Florida State University \\ 239 Bellamy Building \\ Tallahassee, FL 32306 \\ and NBER \\ ckitchens@fsu.edu \\ Luke P. Rodgers \\ lprodgers@fsu.edu
}




\section{Introduction}

Economists and demographers have carefully documented the demographic transition (Galor, 2005; J ones and Tertilt, 2009; Galor and Weil, 2000, Brueckner and Schwandt, 2015). Theory makes sharp predictions regarding the relationship between fertility, income shocks, and changes in the opportunity cost of time (Becker, 1960; Becker and Lewis; 1973; Becker and Tomes, 1976; Rosenzweig, 1977); however, empirical evidence is necessary to understand how the different margins affect net fertility outcomes. Recent literature takes advantage of exogenous variation in income, employment, or wealth to identify their impacts on fertility. ${ }^{4}$ When gender-specific incomes, wages, or wealth data are available, the literature shows that increases in male wages increase fertility, while increases in female wages decrease fertility. ${ }^{5}$ Most of the scholarly evidence comes from the period beginning with the Baby Boom. Scholars know relatively less about the causal factors contributing to fertility decline from the late $19^{\text {th }}$ Century through about $1930 .{ }^{6}$

In this paper, we draw on rich, historical data from the United States to understand how fertility responds to aggregate shocks that change incomes and the relative opportunity costs of women. Specifically, we take advantage of the agricultural commodity boom and bust in the United States surrounding World War I (WWI). During the period we study, 1910-1930, both the General Fertility Rate and Crude Birth rate fell by approximately 29 percent (Figure 1), which is as large a decline as the Baby Boom was a boom. ${ }^{7}$ The agricultural price variation induced by international events

\footnotetext{
4 See Ananat, Gassman-Pines, and Gibson-Davis, 2013; Yonzan, Timilsina, and Kelly, 2020; Fishback, Haines, and Kantor, 2007; Lovenheim and Mumford, 2013; Dettling and Kearney, 2014; Bailey and Collins, 2011; Lewis, 2018; Fujii and Shonchoy, 2020.

${ }^{5}$ For example, Lindo (2010) and Black et al. (2013) document a positive relationship between male wages/ employment and fertility while Wanamaker (2012), Schaller (2016), and Huttunen and Kellokumpu (2017) highlight reductions in fertility for women due to higher wages or employment. ${ }^{6}$ Recent work by Beach and Hanlon (2019) and Spolaore and Wacziarg (2022) highlight the roles of cultural transmission mechanisms in the sharp reduction of fertility beginning in the $19^{\text {th }}$ Century. Earlier work, for instance, that of Alesina, Giuliano, and Nunn (2013) and Voigtlander and Voth (2013) highlights the roles of agricultural technology on gender norms and gender specialization in agriculture and their impacts on fertility. By our time period, many technological changes had begun to reduce the physical constraints in plough agriculture.

${ }^{7}$ The general fertility rate is the number of births per 1,000 women aged 15-44. The crude birth rate is the number of annual live births per 1,000 people in the country's population. See Appendix Figure C1 for a closer view of the 1910-1930 period.
} 
combined with large changes in fertility makes it an ideal setting to explore the link between income shocks and fertility. The agricultural commodity boom in WWI was entirely unexpected as fields in Europe were destroyed. Additionally, the magnitude of the shock was massive. U.S. agricultural exports doubled in the second half of the 1910s; in some cases, prices more than doubled, and agricultural receipts increased by 70 percent (Henderson, Gloy, and Boehlje, 2011). Farmers expected the boom to persist, as documented by rising land prices. ${ }^{8}$ The subsequent bust following the Treaty of Versailles also came as a surprise as Europe rapidly recovered post-war. ${ }^{9}$ We document a close link between female agricultural wages and the crop price variation, which we argue makes changes in female opportunity costs the driving mechanism for the fertility response.

\footnotetext{
${ }^{8}$ Agricultural land prices increased an average of 170 percent nationally by 1920 relative to prewar prices (Table 540, USDA Yearbook of Agriculture, 1931). In places such as Arkansas, Georgia, Mississippi, North Carolina, and South Carolina, average land prices increased between 217-230 percent per acre relative to their prewar levels.

${ }^{9}$ In the years following WWI, significant price volatility remained, at least in part as a result of increased international competition and new domestic policy (i.e., Capper-Volstead Act, 1922, Fordney-McCumber Tariff, 1922).
} 
Figure 1 - United States Fertility Rate 1909-2015

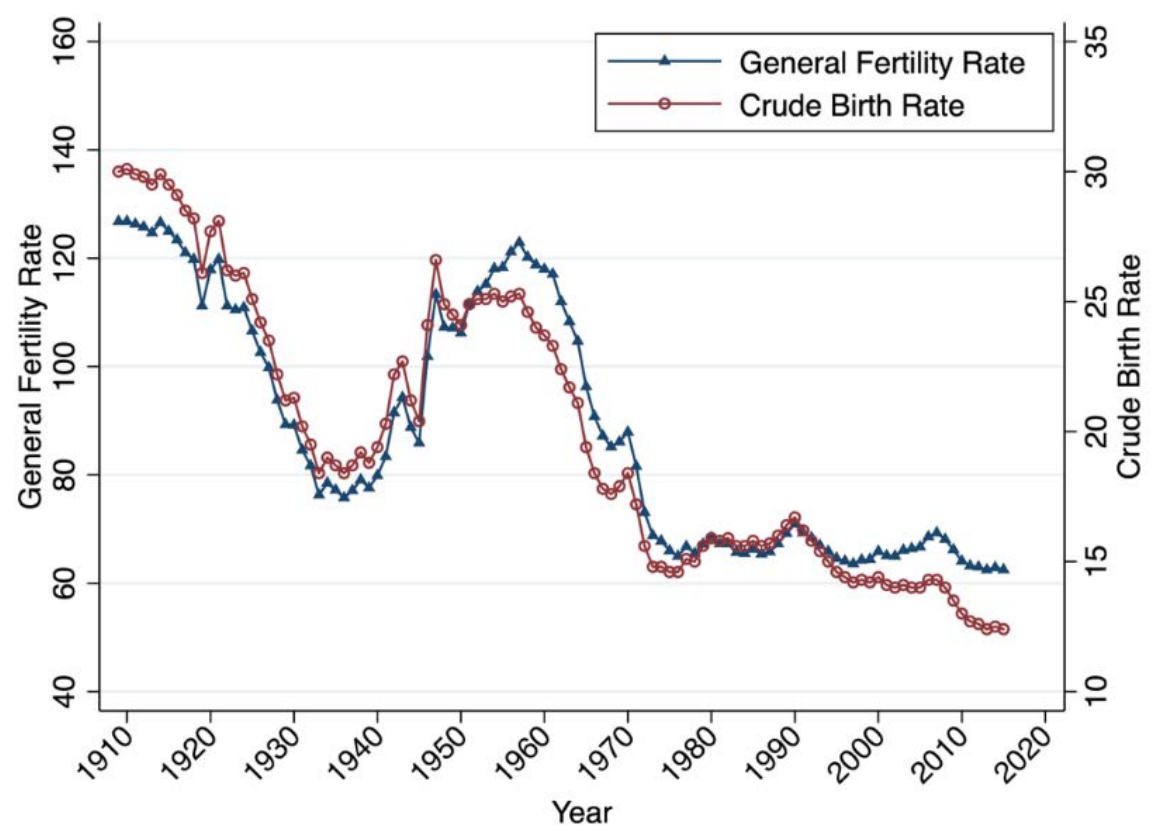

Notes: National Vital Statistics System data (NVSS, 2017). The general fertility rate is the number of births per 1,000 women aged 15-44. The crude birth rate is the number of annual live births per 1,000 people in the country's population.

Limited data has prevented scholars from fully studying the fertility decline in the early $20^{\text {th }}$ Century United States. The federal government did not begin aggregating state-level birth reports until 1915 with the creation of the Birth Registration Area (BRA), which was not complete until Texas joined in 1933. To gain insight into the prewar period, we utilize three different datasets. First, we digitize annual county-level birth tabulations from available state health reports before a state's entry into the BRA to push back the series to 1910 for thirty-two states. This approach allows us to estimate the net change in county-level fertility in response to agricultural price fluctuations using high-frequency data; however, it masks important variation within the county and does not provide full geographic coverage. Second, we use the household structure of the 1930 complete count Census record to construct individual birth histories for each woman of childbearing age. The birth histories provide broad geographic coverage at high frequency, with the caveat that we must assume that women experience price fluctuations in their 1930 location and all relevant children are living in the home. 
Finally, we turn to the complete count Population Census for the years 1910, 1920, and 1930 to compare birth outcomes for women differentially exposed to the agricultural boom and bust, netting out common location and cohort effects. The cohort dataset allows us to consider a larger geographic area than the county-level birth sample and to test for changes in fertility along the extensive and intensive margins, yet this comes at the expense of lower frequency data.

To identify the empirical relationship between changes in fertility and agricultural income changes, we complement our birth data with a measure of annual county-level agricultural crop revenue. Specifically, we augment the approach of Rajan and Ramcharan (2015) and J aremski and Wheelock (2020) to construct a normalized county-level agricultural price index. The index combines pre-war crop production bundles at the county-level with aggregate crop specific price shocks to generate our key source of spatial-temporal variation. We use the index as our measure of agricultural income because annual county-level crop receipts and gender specific wages are otherwise unavailable consistently at a disaggregated level during our period. We then estimate the relationship between the agricultural price index and fertility, controlling for a rich set of covariates, location specific fixed effects, and time fixed effects. Under the assumption that agro-climatic variables drive the initial crop specialization patterns and that international events and climate shocks drive national crop specific prices, variation in the agricultural price index is exogenous to local measures of birth and fertility, thus permitting a causal interpretation for our estimates. We also implement an instrumental variables strategy exploiting crop suitability measures to generate predicted crop shares and find a similar pattern of results.

Across all three datasets, the estimates consistently show that the agricultural boom reduced fertility. In the county-level sample, we estimate that at the average value of the agricultural index, agricultural crop variation led to a 2.6 percent decline in births which explains about 9 percent of the overall decline in fertility between 1910 and 1930. The estimate is robust to various potential confounds, including county-level WWI induction rates that reduced the sex ratio, exposure to the Spanish Influenza Pandemic, and Prohibition controls. Next, we turn to the individual-level birth history panel to 
better understand which women experienced declines in fertility. Here we find that the effect is driven by women living on the farm. ${ }^{10}$ Women living on farms experienced a 0.3 percentage point reduction in the annual probability of birth. Evaluated at the average annual birth probability and mean index, this equates to a 0.6 percent relative decline in the probability of birth. Turning to the complete count census samples, in our preferred sample, we estimate that the number of children under the age of 5 for women in prime childbearing years fell 2.7 percent evaluated at the mean. Using a proxy for long-run fertility, we estimate a 1.5 percent relative decline in the total number of children in the home, indicating that families did not retime fertility. We then test for changes in both the extensive and intensive margins of fertility. Here we estimate that changes at the extensive margin explain about 10-20 percent of the net decline, while changes at the intensive margin explain 80-90 percent. These findings are consistent with theoretical predictions found in Galor (2012) and Aaronson, Lange, and Mazumder (2014), who highlight the effects of increasing the price of child quantity on fertility. Finally, after establishing the reduced-form relationship between the agricultural index and fertility, we investigate multiple potential mechanisms that could explain the negative relationship. We find that the agricultural boom induced women to enter the agricultural labor force and to delay marriage, consistent with the boom increasing opportunity costs.

Our paper contributes to multiple strands of literature. First, our paper complements research that explores the causal relationship between economic shocks and fertility. Our paper fills a gap in the literature regarding demographic changes within the United States before the Baby Boom. Relative to recent work by Ager, Herz, and Brueckner (2020), who examine the impact of the boll weevil on structural transformation and fertility in the American South, our paper examines the broader impacts of agricultural price volatility on family structure and brings several new data sources to light. Second, we view our work as contributing to the broader modern

\footnotetext{
10 Marchingiglio and Poyker (2021) show how industry specific minimum wages during the Progressive Era affected male and female employment. These laws were generally passed before the outbreak of WWI and typically targeted industrial employment with little impact on agriculture (U.S. Department of Labor, Women's Bureau, 1928).
} 
development economics literature that relates agricultural and natural resource shocks to families and family structure (Beegle, Dehejia, and Gatti, 2006; Kruger, 2007; Akresh, 2009; Cogneau and J edwab, 2012). Our estimates show that agricultural commodity price shocks can also affect the size of the family, which closely relates to Schultz (1985) and Corno, Hildebrandt, and Voena (2020). Finally, our work contributes to recent literature that seeks to understand the economic impacts of WWI, joining a growing body of work that explores family formation in Europe (Abramitzky, Delavande, and Vasconcelos, 2011; Vandenbrouke, 2014; Boehnke and Gay, 2020; and Gay, 2021).

Improving our understanding of how aggregate shocks and agricultural shocks affect income and the opportunity costs of women remains an important goal for researchers and policymakers alike, especially in developing economies. Agricultural commodity prices continue to exhibit high levels of price variation today, particularly in crops such as coffee, tea, and cocoa, and are linked to energy prices and more frequent climate shocks. Policy makers frequently implement policies to alleviate the impacts of volatile energy prices and climate change but may miss important interactions between policy interventions and female opportunity costs that can affect long-run demographics. While our estimates are time and place specific, understanding how shocks to agricultural markets impact family formation is no less relevant in the 21 st century.

\section{World War I Agricultural Boom and Bust}

The 1910s and 1920s were a period of significant volatility within American agriculture. WWI created an unprecedented demand shock for American agricultural products. As war raged in Europe, wheat production fell by over 50 percent in France and Italy, oat production dropped 59 percent in Germany, and livestock plummeted to a quarter of their prewar levels in Denmark (Nourse, 1924). Distress in ocean shipping further increased demands for US products with less exposure on ocean shipping lanes than goods originating from more distant sources, such as Argentina and Australia. In response, prices for American goods rose sharply. In some cases, prices for crops such as potatoes and tobacco increased over 300\% between 1914 and 1919. In Figure 2, we 
highlight the annual variation in crop prices for 12 major crops in the United States relative to their price in $1910 .{ }^{11}$

\section{Figure 2 - Crop Price Variation 1900-1930}

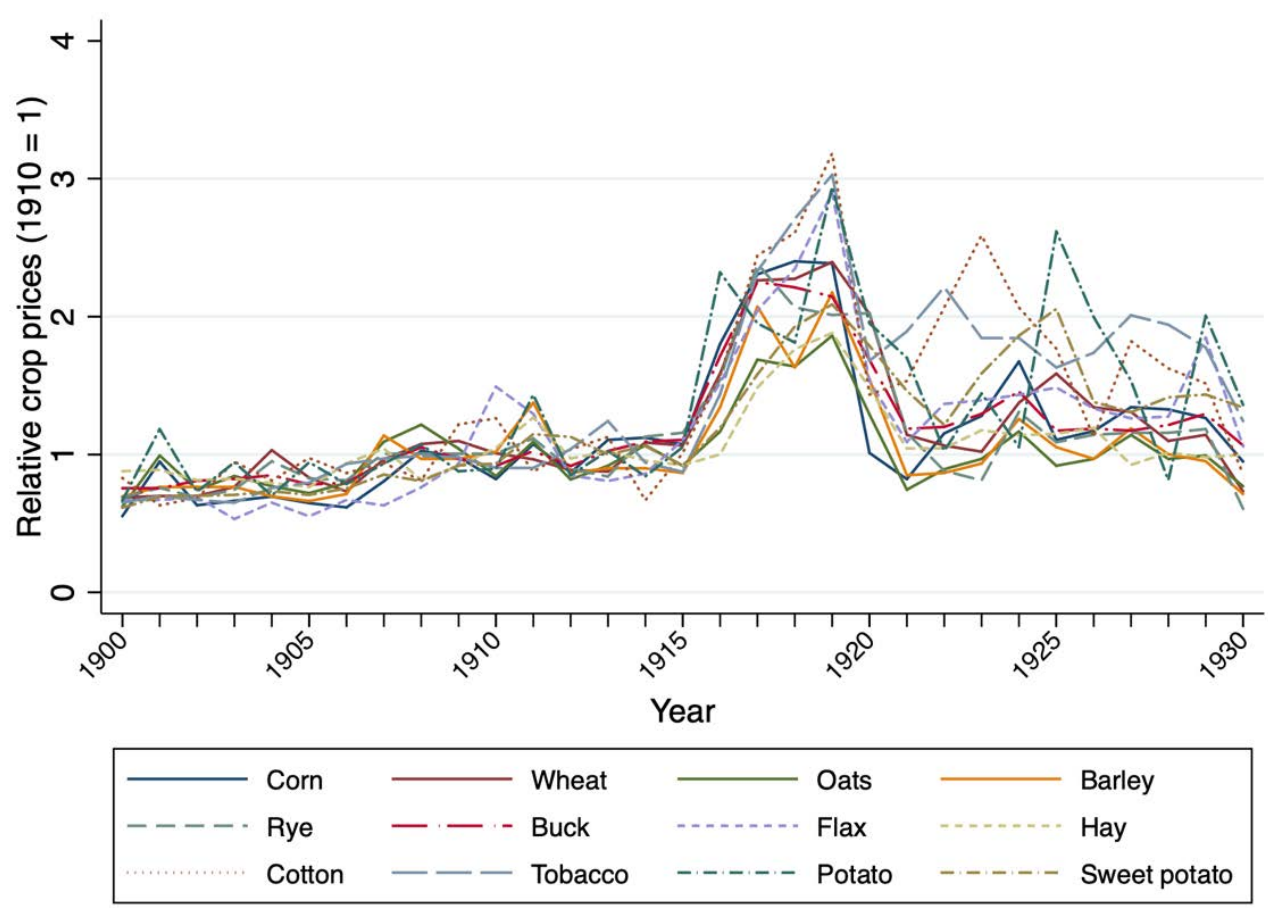

Notes: National price variation for the 12 crops used in the crop index. Data from Carter et al. (2006). Prices are relative to the 1910 baseline.

The rapid increase in agricultural prices caused production in the United States to ramp up. Between 1914 and 1919, 30 million new acres of land were brought into production, representing a 9 percent relative increase (Olmstead and Rhode, 2006). Given the sharp increase in prices and the increased production, the aggregate value of crops harvested in the United States more than doubled over the same time horizon (Acquaye, Alston, and Pardey, 2006). The rapid increase in production strained input markets. Labor was particularly scarce in farm areas. While America's war effort was modest in WWI relative to World War II in terms of manpower, the army drafted over 4

\footnotetext{
${ }^{11}$ We follow Rajan and Ramcharan (2012) and J aremski and Wheelock (2020) in the selection of crops that for the basis of the agricultural price index. These Crops include corn, wheat, oats, barley, rye, buckwheat, flax, cotton, tobacco, potato, and sweet potato. We also include the value of forage crops (hay) to partially account for the impact on livestock markets.
} 
million young men to become doughboys, further tightening the labor market. Ultimately, these factors led to higher wages in agriculture.

How would higher agricultural wages affect fertility? Following models presented in Galor (2012) and Aaronson, Mazumder, and Lange (2014), individuals that maximize utility over consumption and children while investing in child quality will adjust their optimal fertility if either the fixed cost of child rearing changes or if the cost of child quality changes. Factors that increase the fixed cost of raising children, independent of quality investments, lead to declines in fertility along both the extensive and intensive margins. In our context, increasing labor tightness that leads to higher market wages would increase the fixed cost of raising children and should result in declines in fertility along both margins of adjustment. Of course, it is also critical to account for the direct impact that drafting men into the war effort could have on family formation.

Several data sources suggest a close link between wages or economic activity and agricultural receipts. Ideally, we would observe gender specific county-level wages annually and relate changes in wages or income to fertility along both the extensive and intensive margins. However, no data with national coverage exist to test the direct link between gender specific wages and changes in fertility. In Figure 3, Panel A, we report the average annual crop price index described in Section 3. We also plot the national average farm labor wage index from 1910-1930 (USDA, 1931). The USDA labor index closely tracks the crop index before WWI. In 1919, at the peak of the crop index, the wage index doubled from its prewar levels, remaining elevated through the price index bust in 1920. Throughout the 1920s, agricultural wages remained 50 to 70 percent above prewar levels.

Our second piece of evidence linking wages and agricultural receipts comes from Pennsylvania. The Pennsylvania Department of Agriculture reported the weekly wage of women hired as domestic help on farms with board and the annual male wage with board at the county-level between 1908 and 1922. In Figure 3, Panel B, we construct the crop price index for Pennsylvania. In Pennsylvania, the crop index peaked at 2.3 in 1919, while the male and female wage indices peaked in 1920 and remained elevated through 1922. Female wages increased by a factor of 2.2 , while male wages increased by 2.37 . As 
with the national wage data, wages in Pennsylvania remained elevated in the post-war years. These data highlight a strong link between our measured crop index and female wages.

\section{Figure 3 - Agricultural Price Index and Wage Index 1910-1930}

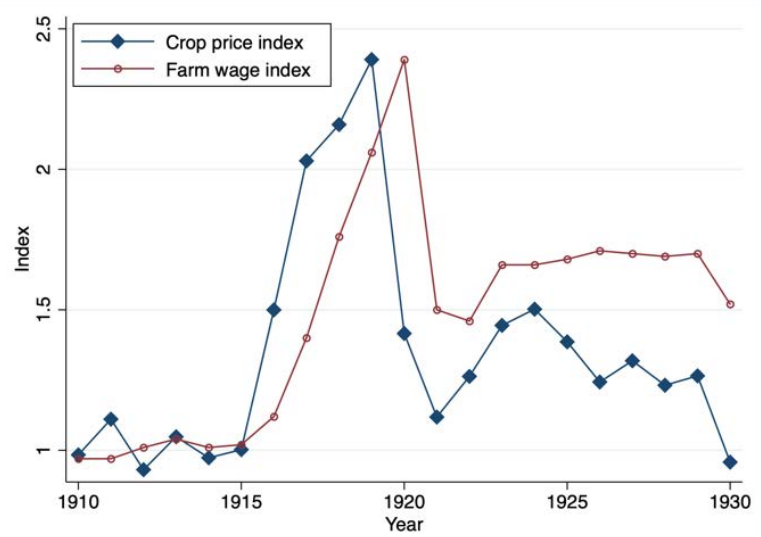

Panel (A)

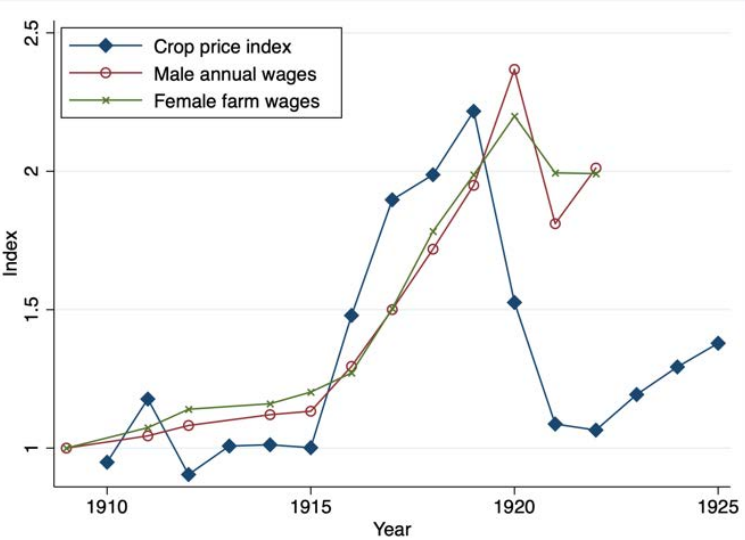

Panel (B)

Notes: Panel A reports the average national crop index over our analysis timeframe. The index is a function of the county's baseline crop mix from 1908 - 1914 and national price fluctuations (Carter et al., 2006). The farm wage index is drawn from the USDA Yearbook of Agriculture (1931). In Panel B, we construct the average crop index in Pennsylvania. Additionally, we report indexed values for the weekly wage of women working on farms with board and the male annual wage, as reported by the Pennsylvania Department of Agriculture's Crop and Livestock report 1906-1922.

There is also a strong positive correlation between our agricultural crop index and local economic activity. In 1930, the Census Bureau reported the total value of countylevel retail activity for the first time. Retail sales have been used extensively in the literature to proxy for income before 1940 (Fishback, Horrace, and Kantor, 2005). Our estimates suggest that a \$1 increase in predicted 1930 farm revenues is associated with a \$1.30 increase in retail sales. We highlight the correlation in Appendix Figure A2.

Finally, there is anecdotal evidence of efforts to alleviate tight labor markets that led to wage gains. Here we provide one example, the Women's Land Army. At its peak, the Women's Land Army recruited upwards of 20,000 women from colleges and universities to work on farms while living in camps (SSA, 1942). In California, women working under the direction of the Women's Land Army earned a minimum wage of $\$ 2 /$ day or the market wage, whichever was greater (Appendix Exhibit A1). Based on 
reports by the USDA published in newspapers in 1918, the wage paid to the Women's Land Army was equivalent to the male daily wage, including room and board (Appendix Exhibit A2). To the extent that there were real wage increases for women in agriculture, this would tend to increase the opportunity cost of childbearing, at least in the shortrun.

The agricultural boom in the US was short-lived and followed by an abrupt and unexpected bust. The fields of Europe recovered quickly following the signing of the Treaty of Versailles. For example, Buyst and Franaszek (2010) report that crop specific yields recovered for most of Europe by 1922. Even Russia, amid a civil war, was able to increase its agricultural output to pre-war levels by the mid-1920s (Markevich and Harrison, 2011). Following the end of WWI, agricultural commodity prices and wages remained elevated, while the vast expansion in agriculture would be the source of foreclosures and financial hardship through the 1920s and 1930s (Alston, 1983; Rajan and Ramcharan, 2015).

\section{Data}

To estimate the relationship between agricultural price volatility and fertility, we combine data from the county-level agricultural Census with three fertility samples. First, we construct a newly digitized dataset of county-level birth counts that predate the Federal Birth Registration Area (BRA), sourced from state health reports between 1910 and 1930 for 32 states. Second, we use the structure of the household record in the 1930 complete count Census to construct annual birth histories for each woman (Ruggles et al., 2020). Third, we use the US Population Census for 1910, 1920, and 1930 (Ruggles et al., 2020) to compare birth outcomes across cohorts of women differentially exposed to the price volatility surrounding WWI.

\subsection{Population and Agricultural Data}

Annual county-level crop income and revenue data do not exist in the period we study. Therefore, we construct an agricultural price index at the county-level, closely following the index suggested by Rajan and Ramcharan (2015) and J aremski and Wheelock (2020). We begin by collecting county-level output for the 12 crops (corn, 
wheat, oats, barley, rye, buckwheat, flaxseed, cotton, tobacco, Irish potatoes, sweet potatoes, and forage crops) from the 1910 Census of Agriculture (Haines, Fishback, and Rhode, 2018). ${ }^{12}$ We then multiply each county's 1910 crop output, $Q_{i, c, 1910}$, by the crop's annual national price, $P_{i, t}$, drawn from Carter et al. (2006) to compute the annual county-level crop revenue. Finally, we normalize the annual county-level crop revenue by the average county-level revenue for the period 1908 and 1914, using the average crop price, $\bar{P}_{l}$.

$$
\text { CropIndex }_{c, t}=\frac{\sum_{i=1}^{12} Q_{i, c, 1910} \times P_{i, t}}{\sum_{i=1}^{12} Q_{i, c, 1910} \times \bar{P}_{\imath}}
$$

By fixing the output at the 1910 value and using national prices, we ensure that the variation we exploit is exogenous to the contemporaneous decisions of local farmers. For instance, we do not have to be concerned with the potential of endogenous crop mixes in response to price movement.

As shown in Figure 3, there is substantial variation in the index over time. Beginning in 1915, when agriculture began to collapse in Europe, crop prices began to rise dramatically. At their peak in 1919, crop prices were over 250 percent higher than pre-WWI levels. Following the Treaty of Versailles signing in 1919, agricultural prices fell dramatically yet remained above their pre-WWI level. While WWI was a significant source of crop price variation, there were also meaningful swings in crop prices throughout the 1920s. Given prewar agricultural production and crop specialization patterns, there was significant heterogeneity in the local intensity of the agricultural boom across space. Cotton, Irish potatoes, tobacco, and flaxseed all experienced price increases exceeding 300\%. Thus, areas such as the Southeast, where cotton and tobacco are grown, experienced relatively larger shocks than the Midwest or West. Similarly, portions of Minnesota and North Dakota experienced relatively larger price spikes due

\footnotetext{
${ }^{12}$ Rajan and Ramcharan (2015) and J aremski and Wheelock (2020) omit forage crops from their index. We include them here because hay and other field grasses account for over 50 percent of cattle feed inputs and are the largest share of acreage in the arid West (https:// www.usdairy.com/newsarticles/do-dairy-cows-eat-food-people-could-eat).
} 
to their production of flax. In Figure 4, we highlight the spatial-temporal variation in the normalized index for 1914, 1919, 1924, and 1929.

In addition to the data from the Census of Agriculture, we merge or construct several county-level economic and demographic variables from the 1910 population census (Haines, 2010). The primary variables we use include the population, sex ratio, share of women living on farms, percent non-white, percent urban, percent aged 6-14, percent illiterate, and value of manufactured goods per capita.

\section{Figure 4 - Spatial Variation in Agricultural Index}

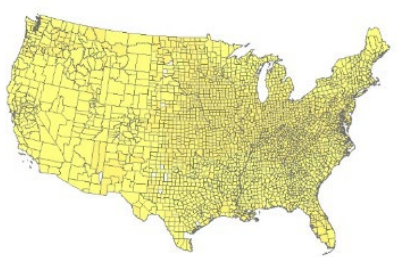

(a) 1914

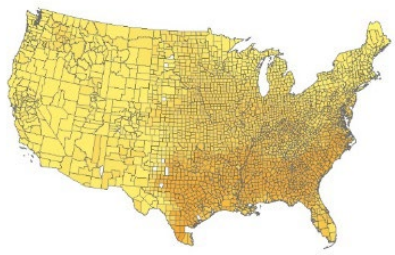

(c) 1924

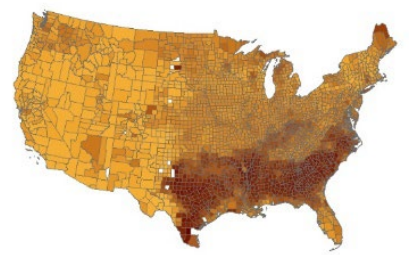

(b) 1919

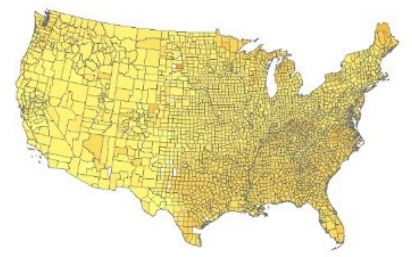

(d) 1929

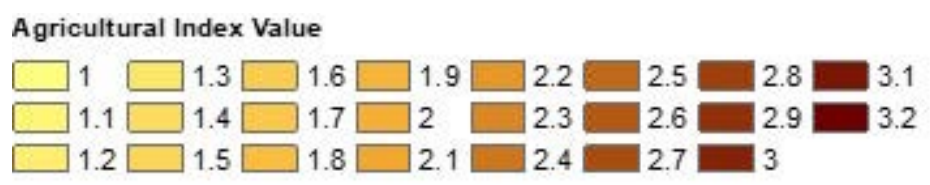

Notes: Four snapshots of the geographic variation in the crop index over our analysis timeframe. WWI caused demand shocks to be concentrated in different counties based on their preexisting crop composition. Data from the Agricultural Census and Carter et al. (2006).

\subsection{Annual County Level Birth Data}

Our first measure of fertility is comprised of county-level birth counts constructed from a combination of Federal Birth Registration Area (BRA) data and State 
Board of Health Reports sources. We begin with county-level birth data reported by the BRA (Eriksson, Niemesh, and Thomasson, 2018). The BRA was formed in 1915 and included ten states at its inception, primarily in the Northeast and upper Midwest. States joined the BRA following an application and certification process, whereby the US Census Bureau verified that the state in question accurately recorded 95 percent of births. The BRA was not complete until 1933 when Texas joined. To supplement these data, we collected and entered county-level birth data using a combination of state health department annual reports, state vital statistics annual reports, and state board of health monthly and quarterly bulletins published before a state entered the BRA back to 1910 . The states collected these data to comply with state-level vital statistics laws that required an accurate count of all births. ${ }^{13}$ To appear in the sample, a state must not have missing data for more than 2 years between 1910 and its entry into the BRA. We construct an annual county-level birth panel covering 32 states between 1910 and 1930 (see Appendix Figure A3). ${ }^{14}$ In Appendix Table A1, we report the year each state in our sample entered the BRA and the years we collected and coded the state-level reports.

The advantage of the county-level data are that they allow us to test for instantaneous responses in fertility associated with the crop index variation at high frequency. These data also ensure we correctly match the birth location to the mother's crop price volatility exposure. However, these data also have limitations. First, the states

\footnotetext{
${ }^{13}$ Shapiro (1950) describes the history of the shift towards federal involvement in the collection of vital statistics. In 1902 the Bureau of the Census became a permanent agency and with the support of Congress, encouraged states to pass a model vital statistics bill drafted in 1905. Ultimately, states have the constitutional authority to collect vital statistics. The model bill, "clearly specified the central authority of the State boards of health over registration matters, provided for the establishment of a strong local apparatus, fixed responsibility for registering births on the attendant at birth (physician, midwife), called for rigid enforcement of the law, and listed a minimum set of items for inclusion on State certificates." Furthermore, the effort to obtain an accurate count was substantial, "The Bureau of the Census, American Public Health Association, United States Children's Bureau and the Public Health Service maintained field representatives on a fulltime basis in various States to assist them in establishing efficient registration systems. Newspapers, theatres, physicians and midwives were enlisted by State and local registrars to promote registration. Civic organizations of the most diverse types (e.g. Federation of Women's Clubs, Boy Scouts of America, American Legion) participated in specific phases of the drive. When a State office felt that its promotional activities had progressed far enough, the Bureau of the Census was requested to carry out a test of registration completeness."

${ }^{14}$ Each state set their own policy in regards to the tracking of vital statistics. In many cases, states did not pass enabling legislation early enough to begin the certification process to enter the Census Birth Registration Area or Death Registration Area during our sample period.
} 
in our sample tend to be in the northeast, upper Midwest, and West. Thus, our countylevel sample does not use the most extreme variation from large swings in cotton and tobacco prices. Secondly, given the reporting accuracy requirements to enter the BRA, an obvious concern with using pre-BRA data is its reliability (i.e., measurement error). ${ }^{15}$ Finally, the birth counts do not allow us to examine whether the net change in fertility is driven by intensive or extensive margin responses or subsets of women within a county.

Our county-level dataset consists of over 32,000 county-year observations. In several specifications, we restrict this sample, dropping counties with populations above the $90^{\text {th }}$ percentile of the 1910 population. We do this to ensure that our estimates are driven by changes in agricultural commodity prices and not by other economic consequences of WWI, such as industrial growth in urban centers. Appendix Table A2 includes summary statistics of the county-level dataset. Unsurprisingly, removing the right tail of the population distribution reduces the mean births per county, manufacturing output per capita in 1900, and the fraction of the population classified as urban in 1910. Otherwise, the restriction does not drastically affect the variable means. We supplement the available control variables mentioned above with extensive fixed effects.

\subsection{Individual Birth History Panel}

In the 1930 complete count Census, we observe all household members, their position in the household, and most importantly, their birth year. Using these records, we construct birth histories for each woman in the continental United States aged 25-45 as of 1930, who is either listed as a spouse or head of household. We assume that all children living in the household belong to the individual listed as the mother. We drop observations where the child's age is larger than the mother's age and those where the mother's age would be implausibly young. For each year, we construct an indicator equal to 1 if the mother gave birth and zero otherwise. This sample enables us to track fertility throughout the entire period for most women, although we must assume that

\footnotetext{
${ }^{15}$ Despite these measurement concerns, we show a 0.99 correlation between the county-level data and birth counts tabulated from the complete count Census when aggregated to the state-year (see Appendix D).
} 
the women experience the agricultural boom and bust in their 1930 location. Over the period 1910-1930, this generates over 256 million mother-year observations in the full sample and over 27 million in our most restrictive subsamples. To identify which women are most affected by the agricultural price shocks, we analyze increasingly restrictive subsets of these data based on county population, farm status, and ownership status. We present summary statistics for subsets of this restricted panel in Appendix Table A3.

In Figure 5, Panel A, we highlight an example of the variation in the data by plotting the annual birth probability for women in the 1895 birth cohort between 1910 and 1930 by the peak intensity of the boom, separated into quartiles. We normalize the data such that all quartiles have a mean of zero in 1914. A few patterns emerge in the raw data. First, as women enter prime childbearing age, there is an upward trend in the probability of giving birth. Secondly, women living in counties that experienced the WWI boom more intensely had lower fertility rates than those who saw smaller increases in the agricultural price index. In Figure 5, Panel B, we plot normalized birth probability for women living on farms. Again, an increase in the birth probability coincides with women entering prime childbearing age. Importantly, the gap between women living in counties that experienced the lowest levels of the WWI shock (Q1) and those who experienced that largest shock (Q4) is much larger for farm women. While this example focuses on a single birth cohort, our empirical strategy generalizes these comparisons to many cohorts and controls for a variety of other variables that influence these trends in the raw data. 
Figure 5 - Normalized Births by Peak Boom Quartile - 1895 Birth Cohort

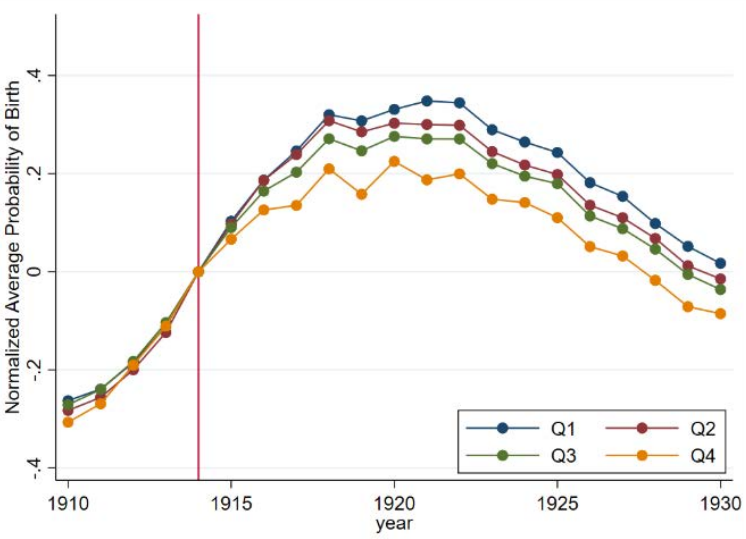

(a) All Women

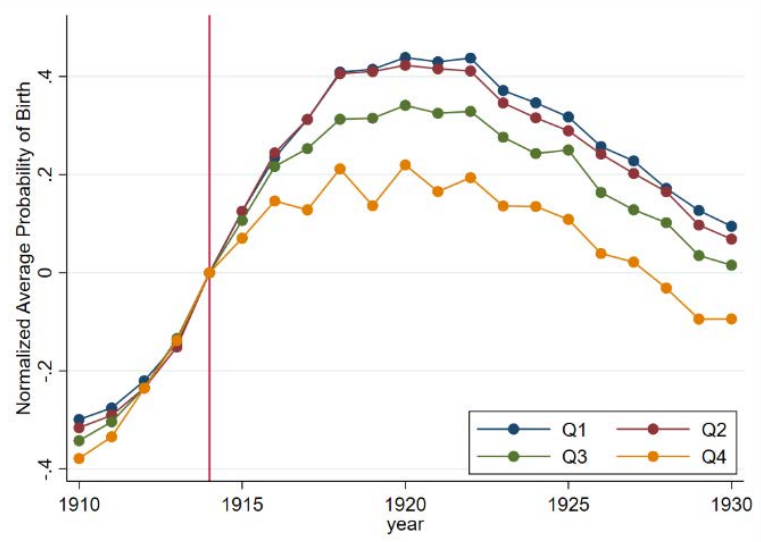

(b) Farm Women

Notes: Probability of giving birth for the 1895 birth cohort by quartile of the peak agricultural boom, normalized by the 1914 value. Birth patterns are similar across the groups before WWI but diverge thereafter, with the largest decreases for areas most affected by the price shock. The pattern is more pronounced for women living on farms.

\subsection{Individual Cohort Sample}

Given the limitations of the county-level birth and birth history datasets, we turn to the complete count Census microdata for 1910, 1920, and 1930 (Ruggles et al., 2020). We include summary statistics for the census data in Appendix Table A4. In this sample, we focus on women aged 16-49 who are spouses or householders and not living in group quarters. We again exclude Hawaii and Alaska from the analysis. Across the three waves of the census, this amounts to over 49 million woman-year observations. In several specifications, we limit our attention to women who were more likely of childbearing age (under 35), of which there are approximately 25 million observations in the sample. As expected, women in the under 35 sample have more children under five and fewer total children than the full sample. We consider similar population restrictions, dropping women living in the most populated counties. The population restricted under the age of 35 sample contains just over 12 million women. Restricting the sample to less populated areas increases the probability that a woman lives on the farm from 25 percent in the under 35 sample to 46 percent. Women under 35 living in less populated counties have more children and are less likely to be white, reflecting the importance of child labor on farms and our pre-Great Migration period of analysis. The final two columns of 
Appendix Table A4 focus on slightly older women who are central to our long-run fertility analysis. As expected, this group of women has more total children at home but fewer under the age of five. The complete count data have the advantage in that they enable us to consider changes in fertility along the intensive and extensive margins; however, we lose time variation due to infrequent observation.

\section{Empirical Strategy}

In what follows, we seek to estimate the reduced form relationship between a measure of fertility and the agricultural index. Due to the differences in how we measure fertility across the three samples, we must adapt our empirical specification to the data. Ideally, we would observe births and income every year. Even with these ideal data, a naïve regression of births on income would likely produce biased results for two reasons. First, births may have a causal impact on income. This is particularly a concern in agriculture, where children provide labor for the family. Second, omitted variables affecting income and fertility could bias the estimates in a naïve regression; health and productivity are two examples of important characteristics that cannot be directly measured yet surely play a role in determining births and income. To address these concerns, we exploit plausibly exogenous variation in the prices of different crops. When we use the annual county-level birth count dataset derived from state health reports, we define the following empirical model:

$$
\text { LogBirths }_{c, t}=\alpha+\text { dindex }_{c, t-1}+X_{c, 1910}^{\prime} \beta_{t}+\tau_{t}+\sigma_{c}+\epsilon_{c, t} .
$$

The dependent variable is the log number of births in county $\mathrm{c}$ and year $\mathrm{t}$. The primary coefficient of interest is $\phi$ which should capture the net effect of the lagged crop index on county births. ${ }^{16}$ Year $(\tau)$ and county $(\sigma)$ fixed effects account for national differences over time and stationary differences between counties, respectively. The vector $\mathrm{X}$ is comprised of interactions between the year fixed effects and baseline county-level characteristics. These controls are measured in 1910 and include the sex ratio, share of women living on farms, and the fraction of the population who is non-white, between

\footnotetext{
16 We have also estimated the model using the contemporaneous value of the crop index. Our estimates are robust to using either definition of the agricultural index. Additionally, our estimates are robust to alternate definitions of the dependent variable, including the birth rate and birth rate per female of childbearing age, see Appendix Table A5.
} 
ages 6 and 14, illiterate, and living in urban areas with over 2500 residents. We include these measures to account for differences in the demographic composition that affect fertility outcomes. We also interact year fixed effects with county-level manufacturing output per capita in 1900. By interacting these baseline observable characteristics with year fixed effects, this specification should net out differential trends in these dimensions that the lagged crop index may otherwise pick up.

The individual birth history dataset dictates a similar empirical model that we define as follows:

$$
Y_{i, c, t}=\alpha+\phi \operatorname{Index}_{c, t-1}+X_{i, c, t}^{\prime} \beta+\tau_{t}+\sigma_{c}+\epsilon_{i, c, t} .
$$

Here, $Y_{i, c, t}$ is a binary outcome equal to one if the mother (i) living in county c had a birth in year $t$ and is zero otherwise. $\tau_{t}$ is a vector of year fixed effects and $\sigma_{c}$ are countylevel fixed effects. The vector of individual characteristics (X) includes fixed effects for age, race, size of residence location (based on total population), whether the mother lives on a farm, the mother's birthplace, interactions between the year fixed effects and each individual characteristic fixed effect, and every two-way interaction between the individual characteristic fixed effects. $X_{i, c, t}^{\prime}$ also includes the same interactions between the year fixed effects and baseline county characteristics described above (sex ratio, manufacturing per capita, etc.).

Finally, when we employ the individual cohort sample, estimating the impact of the crop index on births requires alternative specifications due to the timing of the data collection and variable availability. Ideally, we would be able to use a measure of completed fertility; however, this variable is not available in either the 1920 or 1930 Census. ${ }^{17}$ The primary dependent variables we use from the complete count data are the number of children under age five, the total number of children in the household, and an indicator of any children in the household. Given the available data, our specification compares women of the same age across Census years, netting out time specific and

\footnotetext{
${ }^{17}$ We are primarily interested in how agricultural prices affected fertility, making the "children ever born" variable another relevant outcome. Unfortunately, this variable is only available in the 1910 and 1940 censuses.
} 
county specific effects. Because the available variables represent the cumulative fertility response over multiple years, we assign each woman a cumulative or average crop index. When investigating the impact on children under the age of five, we use the average county index over the last five years. When focusing on the total number or presence of children, we use the average county index over the previous decade. The general specification when using the census data is:

$$
\operatorname{Kids}_{i, c, t}=\alpha+\phi \operatorname{AvgIndex}_{c, t}+X_{i, c, t}^{\prime} \beta_{t}+\tau_{t}+\sigma_{c}+\epsilon_{i, c, t} .
$$

The observations are at the mother (i), county of residence (c), and census year (t) level. The index variable is one of those described above and is assigned to each mother based on her age and county of residence. We include Census year fixed effects $(\tau)$ and county fixed effects $(\sigma)$. The vector of individual characteristics (X) is identical to that described above regarding the individual birth history analysis, except that the year interaction terms use the Census survey year. The dependent variable is either the number of children under age five at the time of the census, the woman's total number of kids at the time of the census, an indicator of any children in the household, or the number of children in the household conditional on having at least one child present. The latter two measures allow us to directly examine fertility responses along the extensive and intensive margins.

Equations (1) through (3) address the same underlying question: how did agricultural commodity price variation affect fertility decisions? In general, our estimates capture a composite effect due to male income effects, increased female opportunity costs, wealth effects, and other potential mechanisms, such as increased direct costs associated with child rearing. Ex-ante, the sign could be positive or negative, depending on the relative magnitudes of the different underlying mechanisms. Supposing for the moment that the only mechanisms were gender specific income responses, a positive coefficient would not inform us of the sign of the female opportunity cost mechanism. A negative coefficient suggests that any opportunity cost effects dominate the male income effect. 
Additionally, it is unclear whether the estimates from the empirical models should point in the same direction. For instance, fertility could immediately fall during the wartime boom due to increased labor scarcity and the increased opportunity cost of childbearing. However, at the war's conclusion, as labor demand subsides and the supply constraint becomes less binding, women may retime fertility, resulting in no net change in total children in the long-run. Similarly, the sudden wealth shock could lead to an immediate increase in childbearing, while in the long-run, there is no change in the total number of children born.

Our agricultural index must be exogenous to local fertility patterns to interpret our estimates as causal. One may be concerned that individuals time fertility in expectation of future shocks to the agricultural price index, such that fertility is not exogenous to current crop price index variation. To test for this, we specify a set of placebo regressions where we regress the leads and lags of the agricultural price index in $t+r$ on current period fertility. The estimates from these regressions, reported in Appendix Table A6, suggest that current fertility levels depend on prior crop price variation, but current fertility levels do not respond to future crop price variation once serial correlation dies out (i.e., beginning with $\mathrm{r}=2$ ). ${ }^{18}$

Additionally, implicit in our index is the underlying assumption that the baseline county-level crop share weights, $Q_{i, c, 1910}$, are exogenous. Recently, economists have raised concerns that the weights in shift-share variables may generate a source of bias (Goldsmith-Pinkham, Sorkin, and Swift, 2020). In our context, agro-climatic variables such as precipitation, temperature, soil type, and the biological pest environment likely drive agricultural productivity and crop choice decisions. To explore this issue, we also employ an instrumental variables strategy where we use measures of crop suitability from the United Nation's Food and Agriculture Organizations Global Agro-Ecological Zones (FAO-GAEZ). We then create a predicted index using predicted crop shares based on suitability for each variety in each county, following the approach of Fiszbein (forthcoming), average crop yields, and national crop prices. We include a full

\footnotetext{
18 We also specify a set of regressions where we place the index on the left-hand side and our controls on the right-hand side. We find little evidence that the index is correlated with these controls.
} 
description of the instrumental variables approach in Appendix B. Generally, the IV estimates are larger in magnitude than the fixed effects estimates we discuss in the text; thus, we present the more conservative estimates.

\section{Estimates}

Below we present our estimates from several different empirical specifications. We discuss our estimates associated with each sample: the county-level panel, the individual birth history panel, and the cohort sample. Following our discussion of the county-level estimates, we describe several robustness checks that address many potential confounds common across the samples. We then discuss our estimates from the two Census samples.

\subsubsection{Short-Run Fertility Effects of Agricultural Boom - County-level data}

In Table 1, we report our estimates from equation (1) with standard errors clustered at the state-level in parentheses. Our estimates are robust to several different assumptions regarding standard errors. ${ }^{19}$ Using the county-level sample, we find that doubling the agricultural price index results in a statistically significant 11.6 log point reduction in births. After dropping the most populated counties, the estimated decline in births increases to $13 \log$ points. When we include our set of county-level covariates in Column (3), the magnitude of our estimate falls slightly, declining to 11.2 log points. In Column (4), we include state-by-year fixed effects, which is a very restrictive specification provided that most of our variation is driven by cross-sectional differences in crop suitability. When we do this, the coefficient estimate falls slightly to -0.083 and is marginally statistically insignificant due to the larger standard errors. Given an average of 438 births per county, our preferred estimates suggest that a doubling of agricultural prices results in 40 to 60 fewer births per county-year. Our most conservative estimates suggest a 2.6 percent reduction in fertility when evaluated at the

\footnotetext{
${ }^{19}$ Clustering at the state level generates the most conservative estimates. Clustering at the county level or computing Conley (1999) standard errors for the county sample using a distance cutoff of 100 miles results in smaller standard errors.
} 
average index. Given the 29-percentage point decline in aggregate fertility, 1910-1930, the agricultural price volatility explains about 9 percent of the overall decline.

Table 1 - State Health Report Estimates, Fertility 1910-1930

\begin{tabular}{|c|c|c|c|c|}
\hline $\mathrm{Y}=\ln ($ County Births $)$ & $(1)$ & (2) & (3) & (4) \\
\hline Ag. Crop Index & $\begin{array}{c}-0.116^{* *} \\
(0.052)\end{array}$ & $\begin{array}{c}-0.130 * * \\
(0.054)\end{array}$ & $\begin{array}{c}-0.112 * * \\
(0.049)\end{array}$ & $\begin{array}{l}-0.083 \\
(0.060)\end{array}$ \\
\hline Population Restriction & & $\mathrm{Y}$ & $\mathrm{Y}$ & $\mathrm{Y}$ \\
\hline Controls & & & $\mathrm{Y}$ & $\mathrm{Y}$ \\
\hline $\begin{array}{l}\text { State x Year FE } \\
\text { Observations }\end{array}$ & 32,146 & 28,732 & 28,732 & $\begin{array}{c}\mathrm{Y} \\
28,732\end{array}$ \\
\hline \multicolumn{5}{|c|}{$\begin{array}{l}\text { Notes: Estimated using the county-level birth records. Every regression includes county and year fixed } \\
\text { effects. Controls include separate interactions between year fixed effects and baseline fractions of the } \\
\text { population in } 1910 \text { who are non-white, between the ages of } 6 \text { and } 14 \text {, illiterate, and living in an urban } \\
\text { area. The controls include year fixed effect interactions with manufacturing output per capita in } 1900 \text {, } \\
\text { the fraction of women living on farms in } 1910 \text {, and the sex ratio in } 1910 \text {. Standard errors clustered at the } \\
\text { state level: } * * * p<0.01,{ }^{* *} p<0.05,{ }^{*} p<0.1\end{array}$} \\
\hline
\end{tabular}

Our findings are strikingly similar to those of Schultz (1985), who examines the impacts of commodity price shocks on crops that utilize gender specific labor in Sweden (butter and grain). Our estimates are also similar in magnitude to those reported by Aaronson, Lange, and Mazumder (2014) for cohorts exposed to the rollout of Rosenwald schools (7.2-9.5 percent) during roughly the same era in the American South. The estimates are also like those reported by Bleakley and Lange (2009), who explore the impact of hookworm eradication in the American South. Our findings depart from recent work by Black, Kolesnikova, Sanders, and Taylor (2013), who document increases in fertility during the Appalachian Coal Boom. As we highlighted earlier, there is direct evidence that female agricultural wages respond to fluctuations in the agricultural price index; thus, our findings are consistent with work by Schaller (2016), who shows that fertility is decreasing in the female wage.

\subsubsection{County-level data - Event Study}

The annual, county-level birth data make it possible to estimate event-study style specifications. To better understand how fertility changed over time, we modify equation (1) by interacting year fixed effects with indicators that denote where in the peak boom (1916-1919) distribution the county is located, by quartile: 


$$
\text { LogBirths }_{c, t}=\alpha+\sum_{k=2}^{4} \delta_{k, t} \tau_{t} \times 1(\text { Index Quartile } c==k)+X_{c, t}^{\prime} \beta+\tau_{t}+\sigma_{c}+\epsilon_{c, t} .
$$

In Figure 6, we plot the $\delta_{k, t}$ coefficients from equation (4), which highlight the relative change in the fertility rate in counties with higher levels of exposure to the boom to those in the bottom quartile of the boom. The first thing to note is that each quartile had similar birth trends leading up to WWI (1910-1914), providing a check on the assumption that underlying trends are not driving our main results. Once prices began to rise in response to WWI-induced demand, the birth patterns of each boom quartile diverged according to the intensity of their respective shock. ${ }^{20}$ While many of the $95 \%$ confidence intervals overlap, the pattern is consistent with the expected timing and intensity of the variation we exploit. Additionally, given that the drop in fertility began during WWI, this suggests that our findings are driven by individuals responding to the boom and not the collapse in agricultural markets following the war's conclusion.

${ }^{20}$ The main results are similar when restricting the analysis window to end immediately after the post-WWI bust; the most substantial identifying variation is due WWI-related shocks. 


\section{Figure 6 - Quartile event study results}

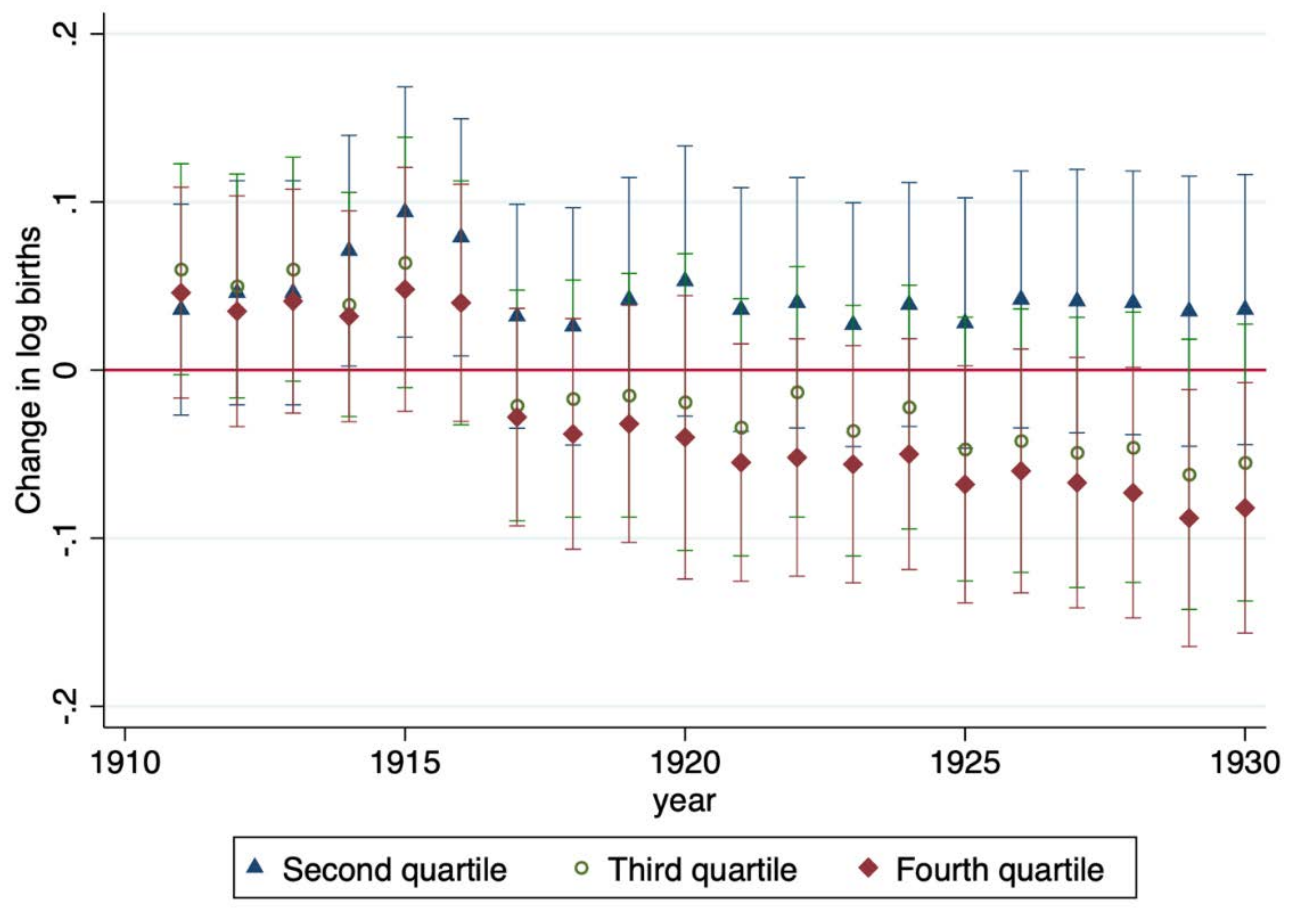

Notes: Coefficients on the interaction between year fixed effects and dummy variables for the top three price index quartiles. 95\% confidence intervals based on county-level clustering are shown.

\subsubsection{County-level data - Robustness}

We begin exploring the robustness of our findings by considering changes to the sample and by accounting for unobserved trends using different functional forms. In Column 2 of Appendix Table A7, we relax our restriction criteria to include three southern states in the analysis (Alabama, Mississippi, and North Carolina) and find little change in the estimated effect. In the same table, we add controls to account for potentially unobserved trends in fertility that might correlate with the agricultural index, for example, unobserved trends in infant mortality. Specifically, we add Census Region linear time trends, state specific linear time trends, and state specific pre-WWI trends. The coefficients remain negative and statistically significant when we include these additional controls.

A common concern across all our samples is the role of migration. For example, there could be a change in the composition of the county population in response to the 
price shocks (i.e., single laborers moving in and families moving out). Selective migration may also be a concern if individuals move from agricultural counties to cities to take advantage of the war industry boom. ${ }^{21}$ Using our annual-county level data, we aggregate births to the state level and construct a state-level analog of the agricultural index. This approach allows for the movement of people within the state, mitigating the influence of intrastate migration, although it does not address interstate migration. We report the estimates of this exercise in Appendix Table A8, Panel A. The estimates are similar when we exclude state-level covariates, but they become imprecise with additional covariates given the small sample size.

Given our sample period, several confounds raise concerns. First and foremost, our estimates could be the byproduct of a reduction in the availability of prime-age males due to the WWI draft. Furthermore, as men returned from Europe, America experienced the Spanish Influenza Pandemic (Almond, 2006; Beach, et al. forthcoming) that hit prime-age males especially hard, which may have also affected fertility patterns. If the spread of the flu correlates with the boom, then our fertility estimates would be biased. Our sample period also contains several secular movements that likely alter the returns to children, either through changes in underlying health risk or their future labor market returns. For example, the period we examine is squarely in the middle of the public health and high school movements. In Appendix C, we describe variables we collect or construct to rule out potential confounders.

Figure 7 presents the estimates when controlling for these additional confounds. Each triangle shows how these controls affect the coefficient on the crop index in regressions using the county-level data. Beginning on the left of Figure 7, we first replicate our preferred baseline estimates from Table 1. Moving from left to right, we add controls to account for the following potential confounders: the number of men

\footnotetext{
${ }^{21}$ Alternatively, in the complete count sample, our model implicitly assumes that individuals experience the intensity of the boom/ bust based on their place of enumeration. In the complete count data, we check for the importance of migration in two ways. First, we restrict the sample to individuals living in their state of birth; secondly, we drop women who were born in a foreign country, given that we do not know when they arrived to the United States. The results are unaffected by these additional sample restrictions, as we show in Panels B- D of Appendix Table A8.
} 
drafted into WWI, exposure to the Spanish Influenza, the rollout of County Health Organizations (CHO), Rockefeller Foundation's Hookworm eradication campaign, exposure to malaria, the presence of a Rosenwald School, changes in compulsory schooling laws, county-level boll weevil infestation, and county-level prohibition policies. The inclusion of these additional controls has little impact on our estimates.

\section{Figure 7 - Robustness checks}

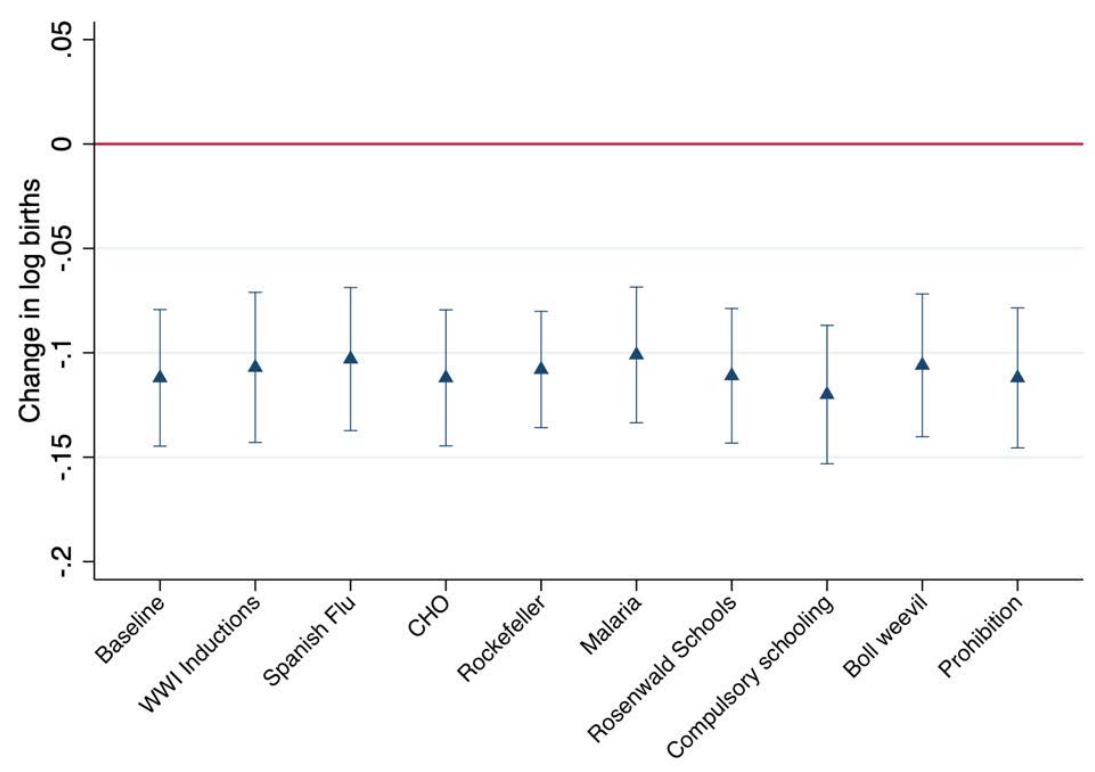

Notes: Coefficients on the one-year lagged crop index when using the annual county-level births as the outcome variable (state reports) with the inclusion of different control variables. 95\% confidence intervals based on state-level clustering are shown.

\subsection{Short-Run Individual Birth History Estimates}

While the county-level data highlights the fertility response to the boom and bust, its geographic coverage is limited, and it cannot pinpoint which women were affected by the agricultural boom. In Table 2, we report estimates from Equation (2). Here we examine six different specifications. First, in Column (1), we report the estimated relationship between the agricultural price index and the probability of birth for all women over 15. We find no statistically significant relationship. This is perhaps not surprising, as many of these women reside in large urban areas where the intensity of the agricultural boom due to local crop specialization has little to no correlation with the labor tightness in the war manufacturing industries. In Column (2), we restrict the 
sample, dropping women who reside in urban areas with a population greater than 50,000 . Here the coefficient becomes more negative but remains statistically insignificant. In Column (3), we add the restriction that the woman must live on a farm. When we add this restriction, we estimate that the probability that a woman has a child falls by 0.42 percentage points, given a doubling of the agricultural price index. In Column (4), we add the set of fully interacted controls. Doing this reduces the magnitude of the estimate slightly to 0.31 percentage points. Women in agriculture have an average annual birth probability of 12 percent, and the average agricultural index value is 1.22 . Thus, the relative decline in the birth probability is 0.6 percent evaluated at the mean birth probability and agricultural index. At the peak of the WWI boom, this translates to a 6 percent reduction in the probability of a woman giving birth. While these estimates are smaller than those estimated in the county-level sample, they are qualitatively similar. In Column (5), we further restrict the sample to focus on women living in rental homes on farms. We do this because this is the set of women who are least likely to experience any wealth effects due to property appreciation, eliminating one of the possible mechanisms through which the agricultural price variation could affect fertility. For this subset of women, the estimated coefficient is slightly larger than the set of all farm women. At the mean birth probability and mean index, this implies a 0.8 percent relative decline in the probability of a birth. The pattern of estimates that emerges as we make these additional restrictions is reassuring, as women in these subpopulations should be most affected by tightness in the agricultural labor market. Column (6) shows that including state-by-year fixed effects does not change the estimate. This finding suggests that state-wide shocks or policy changes do not explain our findings and that the less precise estimate in Column (4) of Table 1 is likely due to power limitations rather than unobservable factors. Finally, the panel nature of the data makes it possible to include mother fixed effects. The similar coefficient in Column (7) indicates that unobservable mother characteristics are not driving our estimates. 
Table 2 - Individual Birth History Estimates, Fertility 1910-1930

\begin{tabular}{|c|c|c|c|c|c|c|c|}
\hline $\mathrm{Y}=\operatorname{Birth}\{0,1\}$ & $(1)$ & $(2)$ & (3) & (4) & (5) & (6) & $(7)$ \\
\hline Ag. Crop Index & $\begin{array}{l}-0.0007 \\
(0.0013)\end{array}$ & $\begin{array}{l}-0.0017 \\
(0.0013)\end{array}$ & $\begin{array}{c}-0.0042 * * * \\
(0.0015)\end{array}$ & $\begin{array}{l}-0.0031^{*} \\
(0.0017)\end{array}$ & $\begin{array}{c}-0.0043^{* * *} \\
(0.0018)\end{array}$ & $\begin{array}{c}-0.0043 * * * \\
(0.0016)\end{array}$ & $\begin{array}{c}-0.0038^{* * *} \\
(0.0010)\end{array}$ \\
\hline Population Restriction & & Y & Y & $\mathrm{Y}$ & Y & $\mathrm{Y}$ & $\mathrm{Y}$ \\
\hline Farm Restriction & & & $\mathrm{Y}$ & $\mathrm{Y}$ & $\mathrm{Y}$ & $\mathrm{Y}$ & $\mathrm{Y}$ \\
\hline Controls & & & & $\mathrm{Y}$ & $\mathrm{Y}$ & $\mathrm{Y}$ & $\mathrm{Y}$ \\
\hline Renter Restriction & & & & & $\mathrm{Y}$ & $\mathrm{Y}$ & $\mathrm{Y}$ \\
\hline State x Year FE & & & & & & $\mathrm{Y}$ & \\
\hline Individual FE & & & & & & & $\mathrm{Y}$ \\
\hline Observations & $256,750,474$ & $157,130,889$ & $53,508,541$ & $53,354,099$ & $27,302,298$ & $27,302,298$ & $27,302,298$ \\
\hline $\begin{array}{l}\text { Notes: Estimated using the } \\
\text { Every regression includes } \\
\text { than } 50,000 \text { residents. The } \\
\text { Controls include fixed eff } \\
\text { of the individual character } \\
\text { interactions between the y } \\
\text { at the state level: } * * * p \\
\text { ( }\end{array}$ & $\begin{array}{l}\text { panel spanning } 1 \\
\text { ounty and year fi } \\
\text { farm restriction d } \\
\text { ts for age, race, } 1 \\
\text { stics, and every ty } \\
\text { ar fixed effects al } \\
01, * * \text { p }<0.05 \text {, }\end{array}$ & $\begin{array}{l}10-1930 \text { based } \\
\text { red effects. The } \\
\text { ops women not } \\
\text { cation populati } \\
0 \text {-way interactic } \\
d \text { the baseline c } \\
\mathrm{p}<0.1\end{array}$ & $\begin{array}{l}\text { the } 1930 \text { com } \\
\text { opulation restri } \\
\text { ving on farms } \\
\text {, farm status, } \mathrm{b} \\
\text { between the it } \\
\text { inty characteris }\end{array}$ & $\begin{array}{l}\text { lete count Cens } \\
\text { ion drops wom } \\
\text { d the renter res } \\
\text { thplace, intera } \\
\text { lividual charac } \\
\text { cs described at }\end{array}$ & $\begin{array}{l}\text { s data. Restrict } \\
\text { n who lived in } \\
\text { riction drops } w \\
\text { ions between } t \\
\text { ristic fixed eff } \\
\text { ve (sex ratio, } \mathrm{e}\end{array}$ & $\begin{array}{l}\mathrm{d} \text { to women ag } \\
\text { laces with pop } \\
\text { men who own } \\
\text { e year fixed eff } \\
\text { ts. The control } \\
\text { c.). Standard er }\end{array}$ & $\begin{array}{l}\text { d } 16-45 . \\
\text { lations greater } \\
\text { eir residence. } \\
\text { cts and each } \\
\text { also include } \\
\text { ors clustered }\end{array}$ \\
\hline
\end{tabular}

As in the county-level sample, we are concerned with the roles that migration and other potential confounds may have on the estimated coefficients. In Appendix Appendix Table A8, Panel B, we report estimates where we exclude individuals living outside their birth state and those born abroad. In Appendix Figure A4, we display estimates from specifications that include previously listed potential confounds (i.e., WWI Inductions). In general, the estimates from these specifications are consistent with the baseline estimates we report in Table $2 .{ }^{22,} 23$

\footnotetext{
22 The county level death data used to construct our measure of excess mortality due to the 1918 Spanish Flu is only available for 31 states. In Panel A of Appendix Table A9 we compare the result from Column (5) of Table 2 to the estimate when we restrict the birth history sample to states from the state health report sample. The coefficient of interest decreases, due to the exclusion of areas most affected by the crop boom and bust. Conditional on this smaller subset of states, controlling for excess mortality does not appear to be an overriding factor.

${ }^{23}$ In Appendix Table A10, we explore heterogeneity by geography and race. Because the boom is heavily concentrated in the South, one may wonder whether our findings are due to something specific regarding cotton or tobacco production. To evaluate this, we re-estimate the model, but allow for differential effects in each Census region. We report the interactions relative to the South. In that exercise, we find that every region, except for the Northeast, experienced a similar reduction in fertility to the South. This is consistent with patterns of urbanization and industrialization, as the Northeast's economy is much different than the South, Midwest, or West. When we test for differential effects by race, we find weak evidence that the effect is concentrated in black women. This is consistent with the literature, such as Boustan and Collins (2014), who show that black women had relatively larger agricultural labor force participation throughout the era.
} 


\subsection{Short-Run Individual Cohort Estimates}

Both samples thus far can speak to the relationship between fertility and the agricultural price index using high-frequency data. However, over a longer time horizon, fertility could return to the long-term trend. We now turn to the complete count individual cohort samples to better understand the long-run dynamics and whether the agricultural boom led to a persistent decline in fertility. We begin by looking at the effect on the number of children under the age of five and then examine outcomes related to fertility over ten years.

In Table 3, we report the estimated impact of the average agricultural price index over the previous five years on the number of children under the age of $5 \mathrm{in}$ the household. We estimate that doubling the price index over five years results in 0.0278 fewer children under the age of five in the home. During our sample period, the average 5-year price index was 1.35, and the average number of children under the age of five was 0.61 . Thus, on average, we estimate that the agricultural boom reduced the number of young children by about 1.6 percent relative to the mean. We estimate a larger effect for younger women, who are more likely to be of childbearing age. For a doubling of the index over five years, we estimate that the coefficient's magnitude increases to -0.04. However, given slightly higher rates of young children in the home (0.85), the relative decline in young children among women under age 35 is still approximately 1.7 percent. For these same young women in the population restricted sample, the effect is slightly larger; we find a 2.7 percent decline in children under age five. Relative to the countylevel data, the implied magnitudes of the estimates are quite similar. In Column 4, we add state-by-year fixed effects. Even under this more restrictive specification, the estimate remains similar in magnitude to our preferred specification reported in Column 3. In Appendix Table A8, Panel C, we show that the effects are similar when we restrict the sample to women living in their birth state or native-born women. Finally, in Appendix Figure A4, we show that the estimates are not sensitive to including potential confounders. 
Table 3 - Short-Run Cohort Estimates, Fertility 1910-1930

\begin{tabular}{|c|c|c|c|c|}
\hline $\mathrm{Y}=$ \#Children Under 5 & (1) & (2) & (3) & (4) \\
\hline Average Ag. Crop Index & $\begin{array}{c}-0.0278^{* *} \\
(0.013)\end{array}$ & $\begin{array}{c}-0.0408^{*} \\
(0.021)\end{array}$ & $\begin{array}{c}-0.0688^{* * *} \\
(0.022)\end{array}$ & $\begin{array}{c}-0.0682 * * * \\
(0.019)\end{array}$ \\
\hline Controls & $\mathrm{Y}$ & $\mathrm{Y}$ & $\mathrm{Y}$ & $\mathrm{Y}$ \\
\hline Age Restriction & & $\mathrm{Y}$ & $\mathrm{Y}$ & $\mathrm{Y}$ \\
\hline Population Restriction & & & $\mathrm{Y}$ & $\mathrm{Y}$ \\
\hline State $\mathrm{x}$ Year FE & & & & $\mathrm{Y}$ \\
\hline Observations & $48,671,889$ & $25,211,910$ & $17,192,278$ & $17,192,278$ \\
\hline \multicolumn{5}{|c|}{$\begin{array}{l}\text { Notes: Estimates using the 1910-1930 complete count Census for women aged 16-49. The age restriction limits } \\
\text { the sample to women under the age of } 35 \text {. The population restriction uses the size of place variable to drop anyone } \\
\text { living in a county with more than } 50,000 \text { residents. Controls include fixed effects for age, race, location } \\
\text { population, farm status, birthplace, interactions between the year fixed effects and each of the individual } \\
\text { characteristics, and every two-way interaction between the individual characteristic fixed effects. The controls } \\
\text { also include interactions between the year fixed effects and the baseline county characteristics described above } \\
\text { (sex ratio, etc.). Standard errors clustered at the state level: } * * * p<0.01, * * p<0.05, * p<0.1\end{array}$} \\
\hline
\end{tabular}

\subsection{Long-Run Individual Cohort Estimates}

We now turn to three longer-run outcomes, the estimates of which we report in Table 4. In Panel A, we report the estimate relating the average agricultural price index over the previous ten years to the total number of children in the household. In Panel B, we report the probability of having children in the home (extensive margin), while in Panel C, we report the number of children, conditional on having children (intensive margin).

Measuring the long-run fertility effects with the complete count data recommends slightly different sample restrictions than those used in the prior samples. We would ideally observe completed fertility or the total number of children born, but the closest variable collected in each of the Census years from 1910-1930 is the total number of children in the household at the time of enumeration. Younger women have not yet finished having children, while older women will no longer have all of their children living at home. For the long-run fertility regressions, we restrict our analysis to women between 30 and 40 . We selected this age window because it will better capture women's total fertility than those under 35. Furthermore, we limit the influence of endogenous household exit of children on our estimates by excluding women older than 40. The final two columns of Appendix Table A4 show that women between the ages of 
30-40 have more total kids in the household but fewer children under the age of five than the under-35 group. They also have more children of any age than the full sample, reflecting the influence of household exit. While the summary statistics suggest that the total number of children for women aged 30-40 is the closest measure to completed fertility reported in the Census, children may have already exited the household at the time of enumeration, and some women in the sample have not completed their fertility.

In Panel A of Table 4, we report estimates of how the average agricultural price index over the previous ten years relates to the total number of children in the home. Here we find that for a doubling in prices over ten years, there is a statistically significant 0.191 reduction in total children relative to a sample mean of 2.19 children. Given an average 10-year price index of 1.19, this suggests that, on average, there was a 1.7 percent reduction in children. Focusing on women between the ages of 30-40, we estimate a statistically significant negative coefficient of 0.218 . Evaluated at the mean number of children and the average price index experienced by women aged 30-40, this implies a 1.6 percent decline in children. Restricting the population, we estimate a negative coefficient of 0.250 , which translates to a 1.6 percent decline in total children. The estimates remain similar when we add state-year fixed effects (Column 4). In Appendix Table A8, Panel D, we show that the estimates remain similar when accounting for migration. 
Table 4 - Number of Children in Home

\begin{tabular}{|c|c|c|c|c|}
\hline & (1) & (2) & (3) & (4) \\
\hline \multicolumn{5}{|c|}{$\frac{\text { Panel A: }}{\text { home }} \mathrm{Y}=\#$ of children in } \\
\hline \multirow[t]{2}{*}{ Average Ag. Crop Index } & $-0.191^{* * *}$ & $-0.218^{* * *}$ & $-0.250 * *$ & $-0.238^{* * *}$ \\
\hline & $(0.064)$ & $(0.073)$ & $(0.107)$ & $(0.092)$ \\
\hline \multicolumn{5}{|l|}{ Panel B: Y = Any kids } \\
\hline Average Ag. Crop Index & $\begin{array}{c}-0.028 * * * \\
(0.010)\end{array}$ & $\begin{array}{c}-0.025^{* *} \\
(0.011)\end{array}$ & $\begin{array}{l}-0.019 * \\
(0.009)\end{array}$ & $\begin{array}{l}-0.015 \\
(0.010)\end{array}$ \\
\hline \multicolumn{5}{|c|}{$\begin{array}{l}\text { Panel C: } \mathrm{Y}=(\# \text { of children in } \\
\text { home } \mid \text { any kids }>0)\end{array}$} \\
\hline Average Ag. Crop Index & $\begin{array}{c}-0.161^{* * *} \\
(0.057)\end{array}$ & $\begin{array}{c}-0.181^{* * *} \\
(0.065)\end{array}$ & $\begin{array}{c}-0.227 * * \\
(0.094)\end{array}$ & $\begin{array}{c}-0.218^{* * *} \\
(0.077)\end{array}$ \\
\hline Controls & $\mathrm{Y}$ & $\mathrm{Y}$ & $\mathrm{Y}$ & $\mathrm{Y}$ \\
\hline Age Restriction & & $\mathrm{Y}$ & $\mathrm{Y}$ & $\mathrm{Y}$ \\
\hline Population Restriction & & & $\mathrm{Y}$ & $\mathrm{Y}$ \\
\hline State $\mathrm{x}$ Year FE & & & & $\mathrm{Y}$ \\
\hline Observations (A and B) & $48,671,889$ & $18,002,150$ & $11,849,728$ & $11,849,728$ \\
\hline Observations (C) & $37,524,790$ & $14,718,630$ & $10,056,836$ & $10,056,836$ \\
\hline \multicolumn{5}{|c|}{$\begin{array}{l}\text { Notes: Estimates using the } 1910-1930 \text { complete count Census for women aged } 16-49 \text {. The age restriction limits } \\
\text { the sample to women aged } 30-40 \text {. The population restriction uses the size of place variable to drop anyone living } \\
\text { in a county with more than } 50,000 \text { residents. Controls include fixed effects for age, race, location population, farm } \\
\text { status, birthplace, interactions between the year fixed effects and each of the individual characteristics, and every } \\
\text { two-way interaction between the individual characteristic fixed effects. The controls also include interactions } \\
\text { between the year fixed effects and the baseline county characteristics described above (sex ratio, etc.). Standard } \\
\text { errors clustered at the state level: } * * * p<0.01, * * p<0.05, * p<0.1\end{array}$} \\
\hline
\end{tabular}

How could WWI and elevated agricultural prices lead to a permanent drop in fertility? As Galor (2012) and Aaronson, Lange, and Mazumdar (2014) note, increasing the price of child quantity decreases fertility along both the extensive and intensive margins. Thus, one possibility is that women had fewer children. Another is that more women remained childless. The next two panels of Table 4 explore fertility's extensive and intensive margins. In Panel B of Table 4, we examine changes at the extensive margin, using an indicator that equals one if the woman has any children in the household and is zero otherwise. We report an estimate of -0.028 for the sample of all women (Column 1) and -0.025 for women living in less populated areas (Column 2). Focusing on agricultural households and women between the ages of 30-40 in Column (3), the magnitude of the coefficient falls slightly to -0.019. The inclusion of state-byyear fixed effects in Column (4) produces a statistically insignificant value of -0.015. Evaluated at the index mean, this is a 0.3 percentage point reduction in the probability 
of a woman having children in the household. The relative magnitude of this effect is quite large. For women aged 30-40 in the population restricted sample, only 14 percent of women had no children in the household. Thus, elevated agricultural prices increase childlessness by about 2.1 percent relative to the mean. Broadly, the signs of the estimates are consistent with Aaronson, Lange, and Mazumdar (2014).

Changes along the intensive margin also drive the fertility response. Using the same sample restrictions, Panel C shows that women had fewer children because of higher crop prices, conditional on having children in the home. To put this in context, the coefficients in Panel C range from - 0.161 to - 0.227 in our main samples. These effects are around 80-90 percent of the coefficients in Panel A. The combined results of Table 4 indicate that both intensive and extensive margin responses meaningfully contributed to declines in overall fertility, although intensive margin effects dominate.

\section{Potential Channels and Alternative Mechanisms}

Up to this point, we have provided evidence from three different datasets that fertility declined because of the rising agricultural prices surrounding WWI. Generally, our estimates are a reduced form effect comprised of many potential mechanisms. However, we claim that the estimates are consistent with a female opportunity cost mechanism. This section discusses the opportunity cost channel, the scope of other potential mechanisms, and their impacts on the estimates.

\subsection{Opportunity Cost Channel}

First, in variants of the household fertility model discussed in Galor (2012), shocks to male income should result in increased fertility, while shocks to the female wage should result in declines in fertility because of increased opportunity cost. In our setting, as highlighted in Figure 3, Panel B, male and female wages closely track the agricultural price index. In a simple framework where only the male income effect and the female opportunity cost mechanism exist, our estimates suggest that the female opportunity cost effect more than offsets any male income effect. Thus, one could view our estimates as the lower bound of the true effect's magnitude. Unlike Schultz (1985), 
our empirical design does not permit us to separate male specific agricultural shocks from female specific shocks.

Despite the lack of gender specific crop specialization information, we explore several margins of adjustment highly suggestive of the opportunity cost mechanism. First, we test whether female labor force participation increased in response to higher agricultural prices. Second, we test whether declines in fertility were steeper in locations with higher baseline levels of female labor force participation. Finally, we explore whether marriage was delayed in response to higher agricultural prices, as labor supply, marriage, and fertility were joint decisions during the period.

To measure the female labor supply responses to agricultural price variation, we define a woman as being in the labor force if she lists an industry of occupation in the Census. ${ }^{24}$ We use data from the 1900, 1910, 1920, and 1930 complete count Census and estimate the relationship between female labor supply and the current agricultural index, controlling for the same variables used in the cohort analysis (see the controls used in Table 3, Column 4). ${ }^{25}$ As shown in the first two columns of Appendix Table A11, there is a positive relationship between agricultural prices and female labor force participation. The estimated relationship is stronger when we focus on agricultural work and restrict the sample to young women living in highly agricultural areas. Despite the documented data issues on this topic, the non-negative estimate is reassuring given the coarseness of the labor supply measure.

Next, we explore the heterogeneity of the fertility response across locations with differing levels of baseline female labor force participation. Here we measure the share of women who worked in agriculture in 1900 and construct an indicator equal to one if the county has above median female labor force participation. We then interact this

\footnotetext{
${ }^{24}$ During the period we examine only labor force participation is measured by the Census, therefore we cannot explore changes in labor supply along the intensive margin.

25 We include the 1900 Census because Goldin (1986) highlights that the 1910 Census enumerated unpaid family labor, leading to significant changes in the reported female labor supply, especially in Southern states. We estimate models that also exclude 1910 and find similar, although less precisely estimated coefficients.
} 
variable with the agricultural price index to test for differential declines in fertility. ${ }^{26}$ In the remaining columns of Appendix Table 11, we report the estimates for the countylevel dataset and the cohort sample. We find that places with higher levels of pre-WWI female labor force participation experienced larger declines in fertility in the short-run.

Last, marriage, fertility, and labor force participation are joint decisions. There is direct evidence that increasing wages can delay marriage (Becker, 1981; Blau, Kahn, and Waldfogel, 2000; Hankins and Hoekstra, 2011; J ensen, 2012; Salisbury, 2017) and that delayed marriage reduces fertility (Bharadwaj, 2015). To test whether the agricultural boom delayed marriage, we turn to the individual level panel dataset we used to construct birth histories. Because the 1930 Census reports the age of first marriage, we can construct annual, individual level marriage histories as well. We then estimate Equation (2) using an indicator equal to one if the woman is married and is zero otherwise. These regressions control for the same set of fully interacted controls described in Table 2 and use the same sample restrictions: all women, the population restricted sample, the farm sample, and the subset of farm women who rent. We report our estimates in Appendix Table A12. For the subset of women who lived on farms and in rental homes, the probability of marriage falls by 0.16 percentage points for a doubling of the agricultural index. Evaluated at the mean probability of marriage (4.5 percent), this suggests a 3.6 percent relative decline in the probability of marriage. Our finding of delayed marriage stemming from agricultural booms is consistent with recent work by Corno, Hildebrandt, and Voena (2020). Delayed marriage potentially contributed to lower fertility even if, given the joint nature of this problem, it remains unclear how much of the decreased fertility is due explicitly to marriage delay versus opportunity cost.

\footnotetext{
${ }^{26}$ Alternatively, we also consider a measure of labor intensity that equals one if the county produces above the median level of cotton or tobacco, and zero otherwise. We suggest this measure because it is documented that Southern states had larger increases in unpaid female labor supply (Goldin, 1986) and because women were relatively productive in cotton and tobacco (Olmstead and Rhode, 2011). Using either measure generates a similar pattern of estimates.
} 


\subsection{Alternate Mechanisms}

Outside of the opportunity cost channel, several other factors could have influenced fertility. Rising agricultural prices impact land values and wealth. Food prices also rose, directly increasing the cost of child-rearing. Farmers may have altered their capital-labor ratio, which would affect the demand for child labor. Changing labor laws may have altered the long-run returns of children. Changing sex ratios could have reduced the ability to find a quality mate. Finally, increased agricultural uncertainty could have led to delays in childbearing. Below, we discuss each of these potential mechanisms in detail.

Work by Dettling and Kearney (2014) and Lovenheim and Mumford (2013) document the role of housing appreciation on fertility through changes in wealth (or the cost of housing for renters). Because the WWI agricultural boom affected land markets, any opportunity cost effects could be offset by increasing land wealth. In our individual birth panel dataset, we explored this channel by restricting the sample to those farmers renting their homes and found that low-wealth mothers experienced modestly steeper declines in their probability of a birth relative to all farm women. In our county-level birth sample, we test for the differential impact that owners and renters experienced during the agricultural boom by modifying equations (1) to include an interaction term between the lagged index and the share of farms owner-operated in the county in 1910. We modify equation (3) for the individual cohort sample by interacting owner status with the relevant average crop index. We report the results of these modified specifications in Appendix Table A13. Our estimates broadly suggest that wealth effects may be present but are relatively modest and are not large enough to offset fertility declines.

Another possible factor that could reduce fertility is that food prices move in conjunction with agricultural commodity prices, directly increasing the cost of raising children. Thus, higher food prices could reduce fertility. We think this is unlikely for a few reasons. First, in the individual birth history panel, we only see declines in fertility for women living on farms. Women living in the same county off the farm would experience the same food price effects as those living on farms, making this mechanism 
unlikely. We can also provide indirect evidence that food prices are uncorrelated with local agricultural commodity price shocks. While county-level food price data are unavailable during the period, the Bureau of Labor Statistics reported food prices in large cities as a part of constructing the Consumer Price Index. Using the CPI food price data, we find no statistically significant correlation between the local agricultural index and the BLS city-level food price index, conditional on year and county fixed effects (see Appendix Figure A7). The lack of correlation is also consistent with the rise of national product markets in the late $19^{\text {th }}$ and early $20^{\text {th }}$ Centuries.

Rural areas traditionally lacked credit to finance fixed capital investments, however, Rajan and Ramcharan (2015) and J aremski and Wheelock (2020) point out that the WWI Boom increased the availability of lending and new unit banks opened to fund land and capital purchases during the boom. Indeed, a doubling of agricultural prices increased lending by approximately 24 percent. Given the tight labor markets, availability of cash, and expanded access to savings, it is possible that farmers were able to increase the rate of capital adoption. Adopting additional capital (or rather, a change in the capital-labor ratio) could partially explain the decline in fertility if farm capital substitutes for labor (Rosenzweig, 1977). To explore this mechanism, we construct the ratio of the capital-income to labor-income. We do this because quantities of capital are not reported in the Census of Agriculture, only their value. To construct the value of labor, we multiply the number of individuals listed as farmers by the national agricultural wage, drawn from the USDA (1931). We recognize that this causes some measurement problems given different types of agricultural labor contracts (owners, tenancy, share, laborer). We show that the capital income share-labor income share ratio declines in the short-run (Appendix Table A14), suggesting that labor was the immediate margin of adjustment; however, over longer time horizons (5-10 years), we see no statistically significant change in the ratio. We take this as suggestive evidence that the reorganization of the farm was not driving the estimated decline in fertility.

Recent work, such as Abramitzky et al. (2011), Gay and Boehnke (2020), and Brodeur and Kattan (forthcoming), highlight the role that sex ratios have on marriage and fertility. While sex ratios are important in the marriage market and fertility, we 
directly control for sex ratios in our main regression specifications, and we control for shocks to the sex ratio induced by the WWI draft in our battery of robustness checks. Thus, we have accounted for this potential mechanism as much as possible given data limitations.

Throughout the early 1900s, child labor laws rapidly changed at the state level, although agricultural and domestic labor was frequently excluded (National Child Labor Committee, 1928). A more restrictive child labor policy would reduce the returns to children and thus reduce fertility, as pointed out by (Rosenzweig, 1977). Currently, our specifications include state-by-year fixed effects, and we include controls for compulsory schooling from Goldin and Katz (2008). They note that compulsory schooling and child labor laws were often two sides of the same coin. While our empirical models currently account for long-run changes in child labor policy, contemporary county-level changes related to child labor could affect our estimates. To address this potential mechanism, we construct the share of children ages 10 to 15 that list an industry of occupation in the 1910 Census and interact the measure with year fixed effects. When we include the share of children working in the regression, our estimated relationship between the agricultural price index and fertility is unchanged. ${ }^{27}$

Recent literature has also explored the link between economic uncertainty and fertility. For example, Chabe-Ferret and Gobbi (2021), Clark and Leinteur (2022), and Gozgor, Bilgin, and Rangazas (2021) all document that increases in economic uncertainty reduce fertility. Net of state-by-year fixed effects, the primary source of risk in our setting is production risk stemming from localized weather or climatic events. To ensure that unobservable production risk does not affect our estimates, we estimate specifications that include a 36-month moving average of the Palmer Drought Severity Index, a measure that captures long term drought conditions. ${ }^{28}$ Including drought and

${ }^{27}$ Consistent with a recent literature in development economics (i.e., Kruger, 2007; Beegle, Dehejia, and Gatti, 2009; Soares, Kruger, and Berthelon, 2012; Bai and Wang, 2020; Carillo, 2020), we also find that there is a positive correlation between the agricultural price index and the share of children that list an industry of occupation.

${ }^{28}$ In addition to the Palmer Drought Severity Index (PDSI), we also estimated specifications that include measures of the Standardized Precipitation Index (SPI) or the Standardized Evapotranspiration Precipitation Index (SEPI). Our estimates are not sensitive to the inclusion of any of these indices. 
alternate climatic risk variables do not affect the estimated relationship between the agricultural price index and our fertility measures.

\section{Conclusions}

Identifying the causal relationship between income and fertility is an important goal for economists, with substantial implications for demography and policy design. In this paper, we presented evidence that income shocks that change women's wages and opportunity costs can significantly impact fertility decisions, along both the extensive and intensive margins. The agricultural boom-and-bust of WWI, which differentially affected the wages and output prices of farms across the US based on their preexisting composition of crops, provided the necessary exogenous variation to study how families responded to income shocks. Analysis using newly-digitized annual birth records revealed that counties with larger price shocks experienced larger fertility declines in the short-run. This pattern was confirmed using multiple measures of short-run fertility in the complete count Census data. An important follow-on question is whether women simply retimed their fertility to take advantage of temporary wage increases. This does not appear to be the case: results focusing on the total number of children in the household from the complete count support the conclusion that these price increases lowered the long-run fertility of affected women. Consistent with the notion that rising female wages (higher opportunity costs) were the dominant mechanism, we document that women delayed marriage in response to the elevated agricultural prices. Lowwealth women experienced the largest declines in fertility. Although data limitations prevent us from ruling out the importance of alternative factors, the bulk of the evidence points to female wages as a significant contributor to the decline in fertility over this period.

A large body of the fertility literature focuses on the theoretical tradeoff between quality and quantity or how costs, both opportunity and explicit, have changed over time. Our work compliments this literature and shows that these are the primary underlying forces at play, even though children may directly affect family income in an agricultural setting. This additional dimension is still present in agricultural societies today, even if many other factors (cultural, institutional, etc.) differ from those in the US 
in the early $20^{\text {th }}$ century. Although the roles and expectations of children have changed substantially over the last century, parents still consider economic opportunities when deciding how many children to have. As policymakers consider potential responses to the many challenges that declining fertility presents to existing social programs, the results of this paper serve as a reminder that gender-specific changes to opportunity costs are central to the discussion. Put another way; there is more to the relationship between income and fertility than just income effects.

\section{References}

Aaronson, D., \&Mazumder, B. (2011). The impact of Rosenwald schools on black achievement. J ournal of Political Economy, 119(5), 821-888.

Aaronson, D., Lange, F., \& Mazumder, B. (2014). Fertility transitions along the extensive and intensive margins. American Economic Review, 104(11), 3701-24.

Aaronson, D., Mazumder, B., Sanders, S. G., \& Taylor, E. (2017). Estimating the effect of school quality on mortality in the presence of migration: Evidence from the J im Crow south. Available at SSRN 3045447.

Abramitzky, R., Delavande, A., \&Vasconcelos, L. (2011). Marrying up: the role of sex ratio in assortative matching. American Economic J ournal: Applied Economics, 3(3), 124-57.

Acquaye, Albert K. A., J ulian M. Alston and Philip G. Pardey, "Agricultural output - gross and net value, by crop and livestock: 1910- 1998." Table Da1063-1081 in Historical Statistics of the United States, Earliest Times to the Present: Millennial Edition, edited by Susan B. Carter, Scott Sigmund Gartner, Michael R. Haines, Alan L. Olmstead, Richard Sutch, and Gavin Wright. New York: Cambridge University Press, 2006. http:// dx.doi.org/ 10.1017/ ISBN9780511132971.Da1063-1265

Ager, P., Brueckner, M., \& Herz, B. (2017). The boll weevil plague and its effect on the southern agricultural sector, 1889- 1929. Explorations in Economic History, 65, 94-105.

Ager, P., Herz, B., \& Brueckner, M. (2020). Structural change and the fertility transition. Review of Economics and Statistics, 102(4), 806-822.

Akresh, R. (2009). Flexibility of household structure child fostering decisions in Burkina Faso. J ournal of Human Resources, 44(4), 976-997.

Alesina, Alberto, Paola Giuliano, and Nathan Nunn. "On the origins of gender roles: Women and the plough." The quarterly journal of economics 128, no. 2 (2013): 469-530.

Almond, Douglas. "Is the 1918 influenza pandemic over? Long-term effects of in utero influenza exposure in the post-1940 US population." J ournal of political Economy 114, no. 4 (2006): 672-712.

Almond, Douglas, and Bhashkar Mazumder. "The 1918 influenza pandemic and subsequent health outcomes: an analysis of SIPP data." American Economic Review 95, no. 2 (2005): 258-262.

Alston, Lee J. "Farm foreclosures in the United States during the interwar period." Journal of Economic History (1983): 885-903

Ananat, E. O., Gassman-Pines, A., \& Gibson-Davis, C. (2013). Community-widejob loss and teenage fertility: Evidence from North Carolina. Demography, 50(6), 2151-2171. 
Bailey, M. J., \& Collins, W. J . (2011). Did improvements in household technology cause the baby boom? Evidence from electrification, appliance diffusion, and the Amish. American Economic J ournal: Macroeconomics, 189-217.

Baker, R. B. (2015). From the field to the classroom: the Boll Weevil's impact on education in Rural Georgia. The J ournal of Economic History, 75(4), 1128-1160.

Baker, R. B., Blanchette, J ., \&Eriksson, K. (2020). Long-run impacts of agricultural shocks on educational attainment: Evidence from the boll weevil. The J ournal of Economic History, 80(1), 136-174.

Beach, Brian, Ryan Brown, J oseph P. Ferrie, Martin H. Saavedra, and Duncan Thomas. (forthcoming). Re-Evaluating the Long-Term Effects of In Utero Exposure to the 1918 Influenza Pandemic. Journal of Political Economy.

Beach, Brian, and W. Walker Hanlon. Censorship, family planning, and the historical fertility transition. No. w25752. National Bureau of Economic Research, 2019.

Becker, G. S. (1960). An economic analysis of fertility. In Demographic and economic change in developed countries (pp. 209-240). Columbia University Press.

Becker, G. S.. (1981). A Treatise on the Family. Harvard university press.

Becker, G. S., \& Lewis, H. G. (1973). On the Interaction between the Quantity and Quality of Children. J ournal of political Economy, 81(2, Part 2), S279-S288.

Becker, G. S., \&Tomes, N. (1976). Child endowments and the quantity and quality of children. J ournal of political Economy, 84(4, Part 2), S143-S162.

Beegle, K., Dehejia, R. H., \& Gatti, R. (2006). Child labor and agricultural shocks. J ournal of Development economics, 81(1), 80-96.

Bharadwaj, P. (2015). Impact of changes in marriage law implications for fertility and school enrollment. J ournal of Human Resources, 50(3), 614-654.

Black, D. A., Kolesnikova, N., Sanders, S. G., \& Taylor, L. J . (2013). Are children "normal”? The Review of Economics and Statistics, 95(1), 21-33.

Blau, F. D., Kahn, L. M., \&Waldfogel, J . (2000). Understanding young women's marriage decisions: The role of labor and marriage market conditions. ILR Review, 53(4), 624-647.

Bleakley, H. (2007). Disease and development: evidence from hookworm eradication in the American South. The quarterly journal of economics, 122(1), 73-117.

Bleakley, H., \& Lange, F. (2009). Chronic disease burden and the interaction of education, fertility, and growth. The review of economics and statistics, 91(1), 52-65.

Bleakley, H. (2010). Malaria eradication in the Americas: A retrospective analysis of childhood exposure. American Economic J ournal: Applied Economics, 2(2), 1-45.

Bloome, D., Feigenbaum, J ., \& Muller, C. (2017). Tenancy, Marriage, and the Boll Weevil Infestation, 1892- 1930. Demography, 54(3), 1029-1049.

Boehnke, J ., \& Gay, V. (2020). The missing men: World War I and female labor force participation. J ournal of Human Resources, 57(4).

Boustan, L. P., \& Collins, W. J . (2014). The origins and persistence of Black-White differences in women's labor force participation. Human capital in history: The American record, 205-40.

Brodeur, A., \& Kattan, L. (forthcoming). World War II, the Baby Boom and Employment: County Level Evidence. J ournal of Labor Economics. https:// doi.org/ 10.1086/ 715485 
Brueckner, M., \& Schwandt, H. (2015). Income and population growth. The Economic J ournal, 125(589), 1653-1676.

Buyst, E. \& Franaszek, P. (2010). Sectoral developments, 1914-1945. In S. Broadberry \& K. O’Rourke (Authors), The Cambridge Economic History of Modern Europe (The Cambridge Economic History of Modern Europe, pp.208-231). Cambridge: Cambridge University Press.

Carter, S. B., Gartner, S. S., Haines, M. R., Olmstead, A. L., Sutch, R., \&Wright, G. (2006). Historical statistics of the United States: millennial edition (Vol. 3). Cambridge: Cambridge University Press.

Centers for Disease Control. Communicable Disease Center Activities 1946-1947. Atlanta, Georgia. 1948.

Chabé-Ferret, B., \& Gobbi, P. (2021). Economic uncertainty and fertility cycles: The case of the postWWII baby boom. Working paper.

Clark, A. E., \& Lepinteur, A. (2022). A natural experiment on job insecurity and fertility in France. Review of Economics and Statistics, 104(2), 386-398.

Clay, Karen, J oshua Lewis, and Edson Severnini. Pollution, infectious disease, and mortality: evidence from the 1918 Spanish influenza pandemic. The J ournal of Economic History 78, no. 4 (2018): 1179-1209.

Cogneau, D., \&J edwab, R. (2012). Commodity price shocks and child outcomes: the 1990 cocoa crisis in Cote d'Ivoire. Economic Development and Cultural Change, 60(3), 507-534.

Conley, T. G. (1999). GMM estimation with cross sectional dependence. J ournal of econometrics, 92(1), 145.

Correia, Sergio and Luck, Stephan and Verner, Emil. (2020). Pandemics Depress the Economy, Public Health Interventions Do Not: Evidence from the 1918 Flu. SSRN Working Paper 3561560. http:/ / dx.doi.org/ 10.2139/ssrn.3561560

Corno, L., Hildebrandt, N., \& Voena, A. (2020). Age of marriage, weather shocks, and the direction of marriage payments. Econometrica, 88(3), 879-915.

Dettling, L. J ., \& Kearney, M. S. (2014). House prices and birth rates: The impact of the real estate market on the decision to have a baby. J ournal of Public Economics, 110, 82-100.

Eriksson, K., Niemesh, G. T., \& Thomasson, M. (2018). Revising infant mortality rates for the early twentieth century United States. Demography, 55(6), 2001-2024.

Feigenbaum, J . J ., Mazumder, S., \& Smith, C. B. (2020). When Coercive Economies Fail: The Political Economy of the US South After the Boll Weevil (No. w27161).

Final Report of the Provost Marshall General to the Secretary of War. (1920). U.S. Government Printing Office. Washington, D.C.

Fishback, P. V., Horrace, W. C., \& Kantor, S. (2005). Did New Deal grant programs stimulate local economies? A study of Federal grants and retail sales during the Great Depression. The J ournal of Economic History, 65(1), 36-71.

Fishback, P. V., Haines, M. R., \& Kantor, S. (2007). Births, deaths, and New Deal relief during the Great Depression. The Review of Economics and Statistics, 89(1), 1-14.

Fiszbein, M. (forthcoming). Agricultural Diversity, Structural Change, and Long-Run Development: Evidence from the US. American Economic J ournal: Macroeconomics.

Fujii, T., \& Shonchoy, A. S. (2020). Fertility and rural electrification in Bangladesh. J ournal of Development Economics, 143, 102430. 
Galor, O. (2005). From stagnation to growth: unified growth theory. Handbook of economic growth, 1, 171-293.

Galor, O. (2012). The demographic transition: causes and consequences. Cliometrica, 6(1), 1-28.

Galor, Oded, and David N. Weil. 2000. "Population, Technology, and Growth: From Malthusian Stagnation to the Demographic Transition and Beyond." American Economic Review, 90 (4): 806-828.

Gay, V. (2021). The legacy of the missing men: The long-run impact of World War I on female labor force participation. SSRN Working Paper \#3069582.

Goldin, C. (1990). Understanding the Gender Gap: An Economic History of American Women. New York: Oxford University Press.

Goldin, C., \& Katz, L. F. (2008). Mass secondary schooling and the state: the role of state compulsion in the high school movement. In Understanding long-run economic growth: Geography, institutions, and the knowledge economy (pp. 275-310). University of Chicago Press

Goldsmith-Pinkham, P., Sorkin, I., \& Swift, H. (2020). "Bartik instruments: What, when, why, and how.” American Economic Review, 110(8), 2586-2624.

Gozgor, G., Bilgin, M. H., \& Rangazas, P. (2021). Economic uncertainty and fertility. Journal of Human Capital, 15(3), 373-399.

Haines, Michael R., and Inter-university Consortium for Political and Social Research. Historical, Demographic, Economic, and Social Data: The United States, 1790-2002. Inter-university Consortium for Political and Social Research [distributor], 2010-05-21. https:/ / doi.org/ 10.3886/ ICPSR02896.v3

Haines, Michael, Fishback, Price, and Rhode, Paul. United States Agriculture Data, 1840 - 2012. Ann Arbor, MI: Inter-university Consortium for Political and Social Research [distributor], 2018-0820. https:// doi.org/ 10.3886/ ICPSR35206.v4

Hankins, S., \& Hoekstra, M. (2011). Lucky in life, unlucky in love? The effect of random income shocks on marriage and divorce. J ournal of Human Resources, 46(2), 403-426.

Henderson, J ., Gloy, B., and Boehlje, M. (2011). Agriculture's boom-bust cycles: is this time different? Economic Review, 96(4), 81-103.

Hoehn-Velasco, L. (2018). Explaining declines in US rural mortality, 1910- 1933: The role of county health departments. Explorations in Economic History, 70, 42-72.

Hoehn-Velasco, L. (2019). The Long-term Impact of Preventative Public Health Programs. Working paper. http:// www.laurenhoehnvelasco.com/research/

Hong, S. C. (2007). The burden of early exposure to malaria in the united states, 1850-1860: Malnutrition and immune disorders. The journal of economic history, 67(4), 1001-1035.

Hong, S. C. (2011). Malaria and economic productivity: a longitudinal analysis of the American case. The J ournal of Economic History, 71(3), 654-671.

Hong, S. C. (2013). Malaria: An early indicator of later disease and work level. J ournal of health economics, 32(3), 612-632.

Huttunen, K., \& Kellokumpu, J . (2016). The effect of job displacement on couples' fertility decisions. Journal of Labor Economics, 34(2), 403-442.

Jacks, D., Pendakur, K., \& Shigeoka, H. (2020). Urban Mortality and the Repeal of Federal Prohibition. NBER Working Paper Series, \#28181. 
Jaremski, M., \&Wheelock, D. C. (2020). Banking on the boom, tripped by the bust: Banks and the World War I agricultural price shock. J ournal of Money, Credit and Banking, 52(7), 1719-1754.

J ensen, R. (2012). Do labor market opportunities affect young women's work and family decisions? Experimental evidence from India. The Quarterly J ournal of Economics, 127(2), 753-792.

Jones, L., \&Tertilt, M. (2009). An Economic History of Fertility in the U.S.: 1826-1960. In P. Rupert (Ed.), The Handbook of Family Economics

Kirkpatrick, E., \&Tough, E. (1932). Prohibition and Agriculture. The ANNALS of the American Academy of Political and Social Science, 163(1), 113-119.

Kitchens, C. (2013). The effects of the Works Progress Administration's anti-malaria programs in Georgia 1932- 1947. Explorations in Economic History, 50(4), 567-581.

Kruger, D. I. (2007). Coffee production effects on child labor and schooling in rural Brazil. J ournal of development Economics, 82(2), 448-463.

Lange, F., Olmstead, A. L., \& Rhode, P. W. (2009). The impact of the boll weevil, 1892- 1932. The J ournal of Economic History, 685-718.

Lewis, J . (2018). Infant Health, Women's Fertility, and Rural Electrification in the United States, 19301960. The J ournal of Economic History, 78(1), 118-154.

Lindo, J . M. (2010). Are children really inferior goods? Evidence from displacement-driven income shocks. J ournal of Human Resources, 45(2), 301-327.

Lovenheim, M. F., \& Mumford, K. J . (2013). Do family wealth shocks affect fertility choices? Evidence from the housing market. Review of Economics and Statistics, 95(2), 464-475.

Marchingiglio, R. \& Poyker, M. “The Economics of Gender-Specific Minimum Wage Legislation.” Working Paper. http:// www.poykerm.com/research.html

Markevich, A., \&Harrison, M. (2011). Great War, Civil War, and recovery: Russia's national income, 1913 to 1928. The J ournal of Economic History, 71(3), 672-703.

Moehling, C. M., \& Thomasson, M. A. (2012). The political economy of saving mothers and babies: The politics of state participation in the Sheppard-Towner Program. The J ournal of Economic History, 72(1), 75-103.

National Child Labor Committee (U.S.). (1928). Analysis of state child labor laws. New York City, NY.

Nourse, E. G. (1924). American agriculture and the European market. McGraw-Hill Book Co., New York.

National Center for Health Statistics. (2017). NCHS - Births and General Fertility Rates. National Center for Health Statistics, National Vital Statistics System. Date accessed: 06/01/ 2020. https://data.cdc.gov/NCHS/NCHS-Births-and-General-Fertility-Rates-United-Sta/e6fc-ccez

Olmstead, Alan L. and Paul W. Rhode, "Cropland - acreage harvested and indexes of cropland use and production per acre: 1910- 1990." Table Da661-666 in Historical Statistics of the United States, Earliest Times to the Present: Millennial Edition, edited by Susan B. Carter, Scott Sigmund Gartner, Michael R. Haines, Alan L. Olmstead, Richard Sutch, and Gavin Wright. New York: Cambridge University Press, 2006. http:// dx.doi.org/ 10.1017/ ISBN-9780511132971.Da661-1062

Rajan, R., \& Ramcharan, R. (2015). The anatomy of a credit crisis: The boom and bust in farm land prices in the United States in the 1920s. American Economic Review, 105(4), 1439-77.

Rosenzweig, M. R. (1977). The demand for children in farm households. J ournal of Political Economy, 85(1), 123-146. 
Ruggles, Steven, Sarah Flood, Ronald Goeken, J osiah Grover, Erin Meyer, J ose Pacas and Matthew Sobek. IPUMS USA: Version 10.0 [dataset]. Minneapolis, MN: IPUMS, 2020. https:/ / doi.org/ 10.18128/ D010.V10.0

Salisbury, L. (2017). Women's income and marriage markets in the United States: Evidence from the Civil War pension. The J ournal of Economic History, 77(1), 1-38.

Schaller, J essamyn. (2016). Booms, Busts, and Fertilty: Testing the Becker Model Using Gender-Specific Labor Demand. J ournal of Human Resources, 51(1), 1-29.

Schultz, T. P. (1985). Changing world prices, women's wages, and the fertility transition: Sweden, 18601910. J ournal of Political Economy, 93(6), 1126-1154.

Shapiro, Sam. (1950). Development of birth registration and birth statistics in the United States. Population Studies 4(1), 86-111.

Social Security Administration. Bureau of Employment Security (1942). Employment o Women in War Production. U.S. Government Printing Office. Washington, D.C.

Spolaore, Enrico, and Romain Wacziarg. "Fertility and modernity." The Economic J ournal 132, no. 642 (2022): 796-833.

United States Department of Agriculture. Office of the Secretary - Circular No. 112. (1918). The Farm Labor Problem: Man-Power Sufficient if Properly Mobilized by Cooperation and Community Action. U.S. Government Printing Office. Washington, D.C.

United Stated Department of Agriculture. (1931). Yearbook of Agriculture. U.S. Government Printing Office. Washington, D.C.

United Stated Department of Agriculture. (1964). Farm Production Economics Division: Economic Research Service. Labor Used to Produce Field Crops: Estimates by States. Statistical Bulletin No. 346. U.S. Government Printing Office. Washington, D.C.

United States Department of Labor. (1918). Booklet of Information: U.S. Boys' Working Reserve. U.S. Government Printing Office. Washington, D.C.

United States Department of Labor. (1928). Bulletin of the Women's Bureau, No. 61. The Development of Minimum-Wage Laws in the United States 1912-1927. U.S. Government Printing Office. Washington, D.C.

United States Department of Labor. (1945). War and Postwar Wages, Prices, and Hours 1914-23 and 1939-44. Bulletin No. 852. U.S. Government Printing Office. Washington, D.C.

Vandenbroucke, Guillaume. (2014). "Fertility and Wars: The Case of World War I in France." American Economic J ournal: Macroeconomics, 6 (2): 108-36.

Voigtländer, Nico, and Hans-J oachim Voth. "How the West" Invented" fertility restriction." American Economic Review 103, no. 6 (2013): 2227-64.

Wanamaker, M. H. (2012). Industrialization and fertility in the nineteenth century: Evidence from South Carolina. The J ournal of Economic History, 72(1), 168-196.

Yonzan, N., Timilsina, L., \& Kelly, I. R. (2020). Economic Incentives Surrounding Fertility: Evidence from Alaska's Permanent Fund Dividend (No. w26712). National Bureau of Economic Research. 


\section{Appendix A: Additional Tables and Figures}

Appendix Table A1 - State Entry into Birth Registration Area and State Health Report Data

\begin{tabular}{|c|c|c|c|c|c|}
\hline $\begin{array}{c}\text { Year of Entry into } \\
\text { Birth Registration } \\
\text { Area } \\
\end{array}$ & State & $\begin{array}{l}\text { State Health Report } \\
\text { Years }\end{array}$ & $\begin{array}{l}\text { Year of Entry into } \\
\text { Birth Registration } \\
\text { Area } \\
\end{array}$ & State & $\begin{array}{c}\text { State Health Report } \\
\text { Years } \\
\end{array}$ \\
\hline \multirow[t]{10}{*}{$\underline{1915}$} & Connecticut & $1910-1914$ & $\underline{1919}$ & California & $1910-1918$ \\
\hline & Maine & $1910-1914$ & & Oregon & 1910-1918 \\
\hline & Massachusetts & $1910-1914$ & & New Jersey & $1910-1918$ \\
\hline & Michigan & $1910-1914$ & & Wyoming & 1911-1918 \\
\hline & Minnesota & $1910-1914$ & & Iowa & 1910-1918 \\
\hline & New Hampshire & $1910-1914$ & & Virginia & $1912-1918$ \\
\hline & New York & $1910-1914$ & $\underline{1920}$ & Nebraska & 1911-1916,1918 \\
\hline & Pennsylvania & $1910-1914$ & 1921 & Delaware & $1911-1920$ \\
\hline & Rhode Island & $1910-1914$ & $\underline{1924}$ & North Dakota & $1910-1914,1917-1923$ \\
\hline & Vermont & $1910-1914$ & $\overline{1925}$ & West Virginia & $1910,1912-1924$ \\
\hline$\underline{1916}$ & Maryland & $1910-1915$ & & Missouri & 1911-1920, 1922-1926 \\
\hline \multirow[t]{7}{*}{$\overline{1917}$} & Indiana & $1910-1916$ & 1926 & Arizona & 1912-1925 \\
\hline & Kansas & $1912-1916$ & $\underline{1929}$ & Nevada & 1911-1922, 1924-1928 \\
\hline & Kentucky & $1911-1916$ & 1932 & South Dakota & $1910-1930$ \\
\hline & Ohio & $\begin{array}{c}\text { 1910-1913, 1915- } \\
1916\end{array}$ & & & \\
\hline & Utah & $1910-1916$ & & & \\
\hline & Washington & $1910-1916$ & & & \\
\hline & Wisconsin & $1910-1916$ & & & \\
\hline
\end{tabular}

Notes: A robustness check includes three additional states. Birth data for Alabama and Mississippi are first available in 1913. The earliest birth data for North Carolina is recorded in 1914 


\section{Appendix Table A2 - Summary Statistics, County-Level Data}

\begin{tabular}{lcc|cc}
\hline \hline & \multicolumn{2}{c|}{ Full Sample } & \multicolumn{2}{c}{ Population Restricted Sample } \\
& Mean & Std. Dev. & Mean & Std. Dev \\
\hline Annual births & 985 & $(4075)$ & 438 & $(348)$ \\
Index 1-year lag & 1.30 & $(0.38)$ & 1.30 & $(0.39)$ \\
Fraction owner-operated farm & 0.74 & $(0.13)$ & 0.74 & $(0.13)$ \\
Fraction farm land & 0.72 & $(0.29)$ & 0.73 & $(0.29)$ \\
Fraction non-white & 0.05 & $(0.11)$ & 0.05 & $(0.11)$ \\
Fraction urban & 0.21 & $(0.26)$ & 0.16 & $(0.20)$ \\
Fraction age 6 to 14 & 0.19 & $(0.03)$ & 0.19 & $(0.03)$ \\
Fraction illiterate & 0.04 & $(0.04)$ & 0.04 & $(0.04)$ \\
Manufacturing output per cap & 86.9 & $(121)$ & 65.1 & $(91.9)$ \\
Sex ratio (male/female) & 1.12 & $(0.18)$ & 1.13 & $(0.18)$ \\
Fraction females on farm & 0.45 & $(0.21)$ & 0.49 & $(0.18)$ \\
\hline Note: There are 32,146 observations for the full sample and 28,732 for the restricted sample. The 90 $90^{\text {th }}$ percentile for \\
county population in 1910 was 59,289. Each fraction variable is measured in 1910 while manufacturing output is \\
measured in 1900.
\end{tabular}




\section{Appendix Table A3 - Summary Statistics, Birth History Panel}

\begin{tabular}{|c|c|c|c|c|}
\hline & (1) & $\begin{array}{l}\text { Population } \\
\text { Restriction } \\
\text { (2) }\end{array}$ & $\begin{array}{l}\text { On the farm and } \\
\text { population } \\
\text { restriction } \\
\text { (3) }\end{array}$ & $\begin{array}{l}\text { Renter, on the farm, } \\
\text { and population } \\
\text { restriction } \\
\text { (4) }\end{array}$ \\
\hline Married & $\begin{array}{c}0.92 \\
(0.27)\end{array}$ & $\begin{array}{c}0.94 \\
(0.24)\end{array}$ & $\begin{array}{c}0.97 \\
(0.18)\end{array}$ & $\begin{array}{c}0.96 \\
(0.19)\end{array}$ \\
\hline Age & $\begin{array}{l}35.0 \\
(5.9)\end{array}$ & $\begin{array}{l}35.0 \\
(5.9)\end{array}$ & $\begin{array}{c}35.4 \\
(5.90)\end{array}$ & $\begin{array}{c}34.2 \\
(5.90)\end{array}$ \\
\hline White & $\begin{array}{c}0.90 \\
(0.29)\end{array}$ & $\begin{array}{c}0.90 \\
(0.30)\end{array}$ & $\begin{array}{c}0.85 \\
(0.36)\end{array}$ & $\begin{array}{c}0.77 \\
(0.42)\end{array}$ \\
\hline Rural & $\begin{array}{c}0.56 \\
(0.50)\end{array}$ & $\begin{array}{c}0.91 \\
(0.28)\end{array}$ & $\begin{array}{c}1.00 \\
(0.03)\end{array}$ & $\begin{array}{c}1.00 \\
(0.02)\end{array}$ \\
\hline On farm & $\begin{array}{c}0.21 \\
(0.40)\end{array}$ & $\begin{array}{c}0.34 \\
(0.47)\end{array}$ & $\begin{array}{c}1 \\
(0)\end{array}$ & $\begin{array}{c}1 \\
(0)\end{array}$ \\
\hline $\begin{array}{l}\text { Average lagged } \\
\text { index }\end{array}$ & $\begin{array}{l}1.19 \\
(0.08)\end{array}$ & $\begin{array}{l}1.19 \\
(0.09)\end{array}$ & $\begin{array}{l}1.22 \\
(0.09)\end{array}$ & $\begin{array}{c}1.24 \\
(0.10)\end{array}$ \\
\hline Children under 5 & $\begin{array}{c}0.52 \\
(0.78)\end{array}$ & $\begin{array}{c}0.60 \\
(0.83)\end{array}$ & $\begin{array}{c}0.73 \\
(0.89)\end{array}$ & $\begin{array}{c}0.81 \\
(0.92)\end{array}$ \\
\hline Total children & $\begin{array}{c}2.22 \\
(1.98)\end{array}$ & $\begin{array}{c}2.49 \\
(2.08)\end{array}$ & $\begin{array}{c}3.08 \\
(2.27)\end{array}$ & $\begin{array}{c}3.10 \\
(2.28)\end{array}$ \\
\hline Child born & $\begin{array}{l}0.085 \\
(0.28)\end{array}$ & $\begin{array}{l}0.097 \\
(0.30)\end{array}$ & $\begin{array}{l}0.120 \\
(0.33)\end{array}$ & $\begin{array}{l}0.136 \\
(0.34)\end{array}$ \\
\hline Number of women & $14,305,042$ & $8,751,293$ & 2,936,004 & $1,562,601$ \\
\hline
\end{tabular}




\section{Appendix Table A4 - Summary Statistics, 1910-1930 Complete Count Data}

\begin{tabular}{|c|c|c|c|c|c|}
\hline & $\begin{array}{l}\text { Complete } \\
\text { Count } \\
\text { (1) }\end{array}$ & Under 35 & $\begin{array}{l}\text { Under } 35 \text { and } \\
\text { population } \\
\text { restriction } \\
\text { (3) }\end{array}$ & Ages 30—40 & $\begin{array}{l}\text { Ages } 30-40 \\
\text { and population } \\
\text { restriction. } \\
\text { (5) }\end{array}$ \\
\hline Married & $\begin{array}{c}0.92 \\
(0.26)\end{array}$ & $\begin{array}{c}0.96 \\
(0.20)\end{array}$ & $\begin{array}{c}0.96 \\
(0.19)\end{array}$ & $\begin{array}{c}0.93 \\
(0.25)\end{array}$ & $\begin{array}{c}0.94 \\
(0.23)\end{array}$ \\
\hline Age & $\begin{array}{c}34.0 \\
(8.37)\end{array}$ & $\begin{array}{c}27.1 \\
(4.49)\end{array}$ & $\begin{array}{c}26.7 \\
(4.65)\end{array}$ & $\begin{array}{c}34.5 \\
(2.88)\end{array}$ & $\begin{array}{c}34.4 \\
(2.88)\end{array}$ \\
\hline White & $\begin{array}{c}0.89 \\
(0.31)\end{array}$ & $\begin{array}{c}0.88 \\
(0.33)\end{array}$ & $\begin{array}{c}0.84 \\
(0.37)\end{array}$ & $\begin{array}{c}0.90 \\
(0.31)\end{array}$ & $\begin{array}{c}0.86 \\
(0.35)\end{array}$ \\
\hline Rural & $\begin{array}{c}0.63 \\
(0.48)\end{array}$ & $\begin{array}{c}0.64 \\
(0.48)\end{array}$ & $\begin{array}{c}0.97 \\
(0.16)\end{array}$ & $\begin{array}{c}0.61 \\
(0.49)\end{array}$ & $\begin{array}{c}0.97 \\
(0.17)\end{array}$ \\
\hline On farm & $\begin{array}{c}0.26 \\
(0.44)\end{array}$ & $\begin{array}{c}0.25 \\
(0.44)\end{array}$ & $\begin{array}{c}0.46 \\
(0.50)\end{array}$ & $\begin{array}{c}0.25 \\
(0.43)\end{array}$ & $\begin{array}{c}0.48 \\
(0.50)\end{array}$ \\
\hline 5 year index & $\begin{array}{c}1.35 \\
(0.38)\end{array}$ & $\begin{array}{l}1.35 \\
(0.38)\end{array}$ & $\begin{array}{l}1.36 \\
(0.41)\end{array}$ & $\begin{array}{c}1.35 \\
(0.37)\end{array}$ & $\begin{array}{l}1.36 \\
(0.40)\end{array}$ \\
\hline 10 year index & $\begin{array}{l}1.19 \\
(0.25)\end{array}$ & $\begin{array}{c}1.19 \\
(0.25)\end{array}$ & $\begin{array}{l}1.19 \\
(0.27)\end{array}$ & $\begin{array}{l}1.19 \\
(0.24)\end{array}$ & $\begin{array}{l}1.19 \\
(0.27)\end{array}$ \\
\hline Children under 5 & $\begin{array}{c}0.61 \\
(0.84)\end{array}$ & $\begin{array}{c}0.85 \\
(0.90)\end{array}$ & $\begin{array}{c}0.93 \\
(0.92)\end{array}$ & $\begin{array}{c}0.65 \\
(0.85)\end{array}$ & $\begin{array}{c}0.75 \\
(0.89)\end{array}$ \\
\hline Total children & $\begin{array}{c}2.19 \\
(2.02)\end{array}$ & $\begin{array}{c}1.76 \\
(1.65)\end{array}$ & $\begin{array}{c}1.97 \\
(1.76)\end{array}$ & $\begin{array}{c}2.54 \\
(2.08)\end{array}$ & $\begin{array}{c}2.95 \\
(2.21)\end{array}$ \\
\hline Any kids & $\begin{array}{c}0.77 \\
(0.42)\end{array}$ & $\begin{array}{c}0.74 \\
(0.44)\end{array}$ & $\begin{array}{c}0.77 \\
(0.42)\end{array}$ & $\begin{array}{c}0.82 \\
(0.39)\end{array}$ & $\begin{array}{c}0.86 \\
(0.35)\end{array}$ \\
\hline $\begin{array}{l}\text { County pop. in } \\
1910\end{array}$ & $\begin{array}{c}298,183 \\
(617,923)\end{array}$ & $\begin{array}{c}286,467 \\
(608,816)\end{array}$ & $\begin{array}{c}23,499 \\
(10,435)\end{array}$ & $\begin{array}{c}315,312 \\
(634,304)\end{array}$ & $\begin{array}{c}23,745 \\
(10,497)\end{array}$ \\
\hline Observations & $49,135,132$ & $25,491,494$ & $12,040,980$ & $18,153,900$ & $7,888,122$ \\
\hline \multicolumn{6}{|c|}{$\begin{array}{l}\text { Notes: Complete count census data for 1910-1930. Standard deviations in parentheses. Focusing on the continental United } \\
\text { States, we restrict the sample to women who are spouses or householders, not living in group quarters, and aged 16-49 at the } \\
\text { time of the census. The population restriction drops women who lived in places with populations greater than 50,000 } \\
\text { residents. }\end{array}$} \\
\hline
\end{tabular}




\section{Appendix Table A5 - State Health Report Estimates, Alternate Definitions of Fertility}

\begin{tabular}{|c|c|c|c|}
\hline & $\ln$ (County Births) & Births/Population & Births/\#Females \\
\hline Ag. Crop Index & $\begin{array}{c}-0.112^{* *} \\
(0.049)\end{array}$ & $\begin{array}{c}-0.0014^{* *} \\
(0.0006)\end{array}$ & $\begin{array}{c}-0.0067 * * \\
(0.0030)\end{array}$ \\
\hline Pop. Restriction \& Controls & $\mathrm{Y}$ & $\mathrm{Y}$ & $\mathrm{Y}$ \\
\hline \multicolumn{4}{|c|}{$\begin{array}{l}\text { Notes: Estimated using the county-level birth records }(\mathrm{N}=28,732) \text {. Controls include separate interactions } \\
\text { between year fixed effects and baseline fractions of population in } 1910 \text { who are non-white, between the ages of } \\
\text { and 14, illiterate, and living in an urban area. Controls also include year fixed interactions with manufacturing } \\
\text { output per capita in } 1900 \text {, the fraction of women living on farms in } 1910 \text {, and the sex ratio in } 1910 \text {. The } \\
\text { population restriction drops the counties which are in the top } 10 \text { percent of population in } 1910 \text {. Standard errors } \\
\text { clustered at the state level: } * * * p<0.01, * * p<0.05, * p<0.1\end{array}$} \\
\hline
\end{tabular}

\section{Appendix Table A6 - State Health Report Estimates, Fertility 1910-1930 Independent of Future Shocks}

\begin{tabular}{|c|c|c|c|c|c|c|c|c|c|c|c|}
\hline $\mathrm{Y}=\ln ($ County Births) & $\mathrm{t}-5$ & $\mathrm{t}-4$ & $\mathrm{t}-3$ & $\mathrm{t}-2$ & $\mathrm{t}-1$ & $\mathrm{t}$ & $\mathrm{t}+1$ & $\mathrm{t}+2$ & $\mathrm{t}+3$ & $\mathrm{t}+4$ & $t+5$ \\
\hline Ag. Crop Index & $\begin{array}{l}-0.0376 \\
(0.0222)\end{array}$ & $\begin{array}{c}-0.0681 * * * \\
(0.0231)\end{array}$ & $\begin{array}{c}-0.0757 * * \\
(0.0277)\end{array}$ & $\begin{array}{c}-0.0648 * * \\
(0.0314)\end{array}$ & $\begin{array}{l}-0.112^{* *} \\
(0.0485)\end{array}$ & $\begin{array}{c}-0.0956 * * \\
(0.0452)\end{array}$ & $\begin{array}{c}-0.0620 * \\
(0.0304)\end{array}$ & $\begin{array}{c}-0.0533 \\
(0.0506)\end{array}$ & $\begin{array}{c}0.0143 \\
(0.0715)\end{array}$ & $\begin{array}{c}0.0556 \\
(0.0568)\end{array}$ & $\begin{array}{c}0.0488 \\
(0.0315)\end{array}$ \\
\hline Observations & 21,657 & 23,083 & 24,511 & 25,936 & 28,732 & 28,732 & 27,297 & 25,862 & 24,427 & 22,987 & 21,556 \\
\hline
\end{tabular}




\section{Appendix Table A7 - Additional County-Level Robustness}

\begin{tabular}{|c|c|c|c|c|c|}
\hline $\mathrm{Y}=\ln ($ County Births $)$ & (1) & $(2)$ & (3) & (4) & (5) \\
\hline Ag. Crop Index & $\begin{array}{c}-0.112^{* *} \\
(0.049)\end{array}$ & $\begin{array}{c}-0.081^{*} \\
(0.042)\end{array}$ & $\begin{array}{c}-0.141^{* *} \\
(0.055)\end{array}$ & $\begin{array}{c}-0.107^{* *} \\
(0.046)\end{array}$ & $\begin{array}{c}-0.070 * * \\
(0.034)\end{array}$ \\
\hline Additional southern states & & $\mathrm{Y}$ & & & \\
\hline Census region $\mathrm{X}$ time trend & & & $\mathrm{Y}$ & & \\
\hline State pre-trends & & & & $\mathrm{Y}$ & \\
\hline State $\mathrm{X}$ time trend & & & & & $\mathrm{Y}$ \\
\hline \multicolumn{6}{|c|}{$\begin{array}{l}\text { Notes: } \mathrm{N}=28,732 \text { for each regression except for Column } 2(\mathrm{~N}=32,154) \text {. Each regression includes the } \\
\text { baseline controls and population restriction. Controls include separate interactions between year fixed effects } \\
\text { and baseline fractions of population in } 1910 \text { who are non-white, between the ages of } 6 \text { and } 14 \text {, illiterate, and } \\
\text { living in an urban area. Controls also include year fixed interactions with manufacturing output per capita in } \\
\text { 1900, the fraction of women living on farms in } 1910 \text {, and the sex ratio in } 1910 \text {. The population restriction } \\
\text { drops the counties which are in the top } 10 \text { percent of population in } 1910 \text {. Column } 1 \text { reproduces the preferred } \\
\text { estimate from Column } 3 \text { of Table } 1 \text {. Column } 2 \text { includes AL, MS, and NC. Standard errors clustered at the } \\
\text { state level: } * * * p<0.01, * * p<0.05, * p<0.1\end{array}$} \\
\hline
\end{tabular}




\section{Appendix Table A8 - Robustness to Migration}

\begin{tabular}{|c|c|c|c|}
\hline Panel A: Y = $\ln$ (County Births) & $\begin{array}{c}\text { Baseline } \\
\text { (1) }\end{array}$ & (2) & (3) \\
\hline \multirow[t]{2}{*}{ Ag. Crop Index } & $-0.112 * *$ & -0.113 & -0.044 \\
\hline & $(0.049)$ & $(0.087)$ & $(0.096)$ \\
\hline Population Restriction & $\mathrm{Y}$ & & \\
\hline Aggregated to state level & & $\mathrm{Y}$ & $\mathrm{Y}$ \\
\hline Controls & $\mathrm{Y}$ & & $\mathrm{Y}$ \\
\hline Observations & 28,732 & 652 & 652 \\
\hline Panel B: Y = Birth $\{0,1\}$ & $\begin{array}{l}\text { Baseline } \\
\text { (1) }\end{array}$ & (2) & (3) \\
\hline Ag. Crop Index & $\begin{array}{c}-0.0043^{* * *} \\
(0.0018)\end{array}$ & $\begin{array}{c}-0.0051^{* * *} \\
(0.0018)\end{array}$ & $\begin{array}{c}-0.0048 * * * \\
(0.0018)\end{array}$ \\
\hline Population Restriction & $\mathrm{Y}$ & $\mathrm{Y}$ & $\mathrm{Y}$ \\
\hline Farm Restriction & $\mathrm{Y}$ & $\mathrm{Y}$ & $\mathrm{Y}$ \\
\hline Renter Restriction & $\mathrm{Y}$ & $\mathrm{Y}$ & $\mathrm{Y}$ \\
\hline Live in State of Birth & & $\mathrm{Y}$ & \\
\hline Exclude Foreign Born & & & $\mathrm{Y}$ \\
\hline Observations & $27,302,298$ & $20,453,279$ & $26,168,344$ \\
\hline Panel C: Y = \# Children Under 5 & $\begin{array}{c}\text { Baseline } \\
(1)\end{array}$ & $(2)$ & (3) \\
\hline Avg. Crop Index & $\begin{array}{c}-0.0688^{* * *} \\
(0.022)\end{array}$ & $\begin{array}{c}-0.0777 * * * \\
(0.019)\end{array}$ & $\begin{array}{c}-0.0796 * * * \\
(0.019)\end{array}$ \\
\hline Pop and Age Restrictions & $\mathrm{Y}$ & $\mathrm{Y}$ & $\mathrm{Y}$ \\
\hline Live in State of Birth & & $\mathrm{Y}$ & \\
\hline Exclude Foreign Born & & & $\mathrm{Y}$ \\
\hline Observations & $17,192,278$ & $11,743,302$ & $15,654,327$ \\
\hline Panel D: \# children in Home & $\begin{array}{c}\text { Baseline } \\
\text { (1) }\end{array}$ & (2) & (3) \\
\hline Avg. Crop Index & $\begin{array}{c}-0.250 * * \\
(0.107)\end{array}$ & $\begin{array}{c}-0.256^{* *} \\
(0.108)\end{array}$ & $\begin{array}{c}-0.244^{* *} \\
(0.106)\end{array}$ \\
\hline Pop and Age Restrictions & $\mathrm{Y}$ & $\mathrm{Y}$ & $\mathrm{Y}$ \\
\hline Live in State of Birth & & $\mathrm{Y}$ & \\
\hline Exclude Foreign Born & & & $\mathrm{Y}$ \\
\hline Observations & $11,849,728$ & $7,487,718$ & $10,414,859$ \\
\hline \multicolumn{4}{|c|}{$\begin{array}{l}\text { Notes: Panel A uses the county-level dataset, Panel B uses the birth history panel, and Panels C- D use } \\
\text { the } 1910-1930 \text { complete count data. Every regression includes county and year fixed effects. Every } \\
\text { regression includes separate interactions between year fixed effects and baseline fractions of population } \\
\text { in } 1910 \text { who are non-white, between the ages of } 6 \text { and } 14 \text {, illiterate, and living in an urban area. The } \\
\text { controls also include year fixed effect interactions with manufacturing output per capita in } 1900 \text {, the } \\
\text { fraction of women living on farms in } 1910 \text {, and the sex ratio in } 1910 \text {. Panels B- D include fixed effects } \\
\text { for age, race, location population, farm status, birthplace, interactions between the year fixed effects anc } \\
\text { each of the individual characteristics, and every two-way interaction between the individual } \\
\text { characteristic fixed effects. For Panel A, the population restriction drops counties in the top } 10 \text { percent } \\
\text { of population in } 1910 \text {. For Panels B- D, the population restriction drops anyone living in a location with } \\
\text { more than 50,000 residents. Standard errors clustered at the state level: }{ }^{* * *} \mathrm{p}<0.01 \text {, }{ }^{* *} \mathrm{p}<0.05 \text {, }{ }^{*} \mathrm{p}< \\
0.1\end{array}$} \\
\hline
\end{tabular}




\section{Appendix Table A9 - Sample Overlap and Excess Mortality}

\begin{tabular}{|c|c|c|c|}
\hline Panel A: Y $=\mathrm{Y}=\operatorname{Birth}\{0,1\}$ & $\begin{array}{c}\text { Baseline } \\
(1)\end{array}$ & $(2)$ & $(3)$ \\
\hline Ag. Crop Index & $\begin{array}{l}-0.0043^{* *} \\
(0.0018)\end{array}$ & $\begin{array}{l}-0.0025 \\
(0.0023)\end{array}$ & $\begin{array}{l}0.0013 \\
(0.002)\end{array}$ \\
\hline Population and age restrictions, controls & $\mathrm{Y}$ & $\mathrm{Y}$ & $\mathrm{Y}$ \\
\hline $\begin{array}{l}\text { Only states in county sample } \\
\text { Control for excess mortality (Spanish Flu) }\end{array}$ & & $\mathrm{Y}$ & $\begin{array}{l}\mathrm{Y} \\
\mathrm{Y}\end{array}$ \\
\hline Observations & $27,302,298$ & $10,914,733$ & $12,433,613$ \\
\hline Panel B: Y = \# Children Under 5 & (1) & $(2)$ & (3) \\
\hline Average Ag. Crop Index & $\begin{array}{c}-0.069 * * * \\
(0.022)\end{array}$ & $\begin{array}{l}-0.013 \\
(0.027)\end{array}$ & $\begin{array}{l}-0.016 \\
(0.026)\end{array}$ \\
\hline Population and age restrictions, controls & $\mathrm{Y}$ & $\mathrm{Y}$ & $\mathrm{Y}$ \\
\hline Only states in county sample & & $\mathrm{Y}$ & $\mathrm{Y}$ \\
\hline Control for excess mortality (Spanish Flu) & & & $\mathrm{Y}$ \\
\hline Observations & $17,192,278$ & $10,066,987$ & $9,988,500$ \\
\hline Panel C: Y = \# Children & (1) & $(2)$ & (3) \\
\hline Average Ag. Crop Index & $\begin{array}{c}-0.250 * * \\
(0.107)\end{array}$ & $\begin{array}{l}-0.073 \\
(0.110)\end{array}$ & $\begin{array}{l}-0.094 \\
(0.107)\end{array}$ \\
\hline Only states in county sample & $\mathrm{Y}$ & $\mathrm{Y}$ & $\mathrm{Y}$ \\
\hline Control for excess mortality (Spani & & $\mathrm{Y}$ & $\mathrm{Y}$ \\
\hline Only states in county sample & & & $\mathrm{Y}$ \\
\hline Observations & $11,849,728$ & $7,524,959$ & $7,207,970$ \\
\hline \multicolumn{4}{|c|}{$\begin{array}{l}\text { Notes: Panel A uses the county-level dataset while Panels B-C use the 1910-1930 complete count data. Every } \\
\text { regression includes county and year fixed effects. Every regression includes separate interactions between } \\
\text { year fixed effects and baseline fractions of population in } 1910 \text { who are non-white, between the ages of } 6 \text { and } \\
14 \text {, illiterate, and living in an urban area. The controls also include year fixed effect interactions with } \\
\text { manufacturing output per capita in } 1900 \text {, the fraction of women living on farms in } 1910 \text {, and the sex ratio in } \\
1910 \text {. Panels B and C controls include fixed effects for age, race, location population, farm status, birthplace, } \\
\text { interactions between the year fixed effects and each of the individual characteristics, and every two-way } \\
\text { interaction between the individual characteristic fixed effects. Panel B and C controls also include interactions } \\
\text { between the year fixed effects and the baseline county characteristics described for Panel A (sex ratio, etc.). } \\
\text { For Panel A, the population restriction drops counties in the top } 10 \text { percent of population in1910. For Panels } \mathrm{B} \text {, } \\
\text { and C, the population restriction drops anyone living in a location with more than 50,000 residents. Standard } \\
\text { errors clustered at the state level: } * * * \mathrm{p}<0.01, * * \mathrm{p}<0.05, * \mathrm{p}<0.1\end{array}$} \\
\hline
\end{tabular}




\section{Appendix Table A10 - Heterogeneity by Race and Region}

\begin{tabular}{|c|c|c|c|c|c|c|}
\hline & \multicolumn{2}{|c|}{$\mathrm{Y}=\operatorname{Birth}\{0,1\}$} & \multicolumn{2}{|c|}{$\mathrm{Y}=\#$ children under 5} & \multicolumn{2}{|c|}{$\begin{array}{c}\mathrm{Y}=\text { total children in } \\
\text { household }\end{array}$} \\
\hline & (1) & (2) & (3) & $(4)$ & $(5)$ & (6) \\
\hline Ag. Crop Index & $\begin{array}{l}-0.002 \\
(0.002)\end{array}$ & $\begin{array}{l}-0.004^{* *} \\
(0.002)\end{array}$ & $\begin{array}{c}-0.070^{* * *} \\
(0.024)\end{array}$ & $\begin{array}{c}-0.083^{* * *} \\
(0.021)\end{array}$ & $\begin{array}{c}-0.286^{* *} \\
(0.114)\end{array}$ & $\begin{array}{c}-0.298^{* *} \\
(0.114)\end{array}$ \\
\hline Black X Ag. Crop Index & $\begin{array}{l}-0.016 * \\
(0.009)\end{array}$ & & $\begin{array}{c}0.019 \\
(0.070)\end{array}$ & & $\begin{array}{c}0.411 \\
(0.290)\end{array}$ & \\
\hline Northeast X Ag. Crop Index & & $\begin{array}{l}0.006^{* *} \\
(0.003)\end{array}$ & & $\begin{array}{c}0.051 * * * \\
(0.019)\end{array}$ & & $\begin{array}{l}0.097 \\
(0.088)\end{array}$ \\
\hline Midwest X Ag. Crop Index & & $\begin{array}{l}-0.0001 \\
(0.001)\end{array}$ & & $\begin{array}{l}0.021^{*} \\
(0.011)\end{array}$ & & $\begin{array}{l}0.023 \\
(0.074)\end{array}$ \\
\hline West X Ag. Crop Index & & $\begin{array}{c}0.002 \\
(0.003)\end{array}$ & & $\begin{array}{c}-0.001 \\
(0.023)\end{array}$ & & $\begin{array}{l}-0.155 \\
(0.133)\end{array}$ \\
\hline Observations & $27,137,678$ & $27,302,298$ & $17,118,572$ & $17,192,278$ & $11,803,940$ & $11,849,728$ \\
\hline \multicolumn{7}{|c|}{$\begin{array}{l}\text { Notes: Columns 1-2 use the birth history panel while Columns 3-6 use the 1910-1930 complete count census data (cohort } \\
\text { sample). Every regression includes county and year fixed effects. Every regression includes separate interactions between year } \\
\text { fixed effects and baseline county fractions of population in } 1910 \text { who are non-white, between the ages of } 6 \text { and } 14 \text {, illiterate, } \\
\text { and living in an urban area. The county-level controls also include year fixed effect interactions with manufacturing output per } \\
\text { capita in } 1900 \text {, the fraction of women living on farms in } 1910 \text {, and the sex ratio in } 1910 \text {. Individual controls include fixed } \\
\text { effects for age, race, location population, farm status, birthplace, interactions between the year fixed effects and each of the } \\
\text { individual characteristics, and every two-way interaction between the individual characteristic fixed effects. Each regression } \\
\text { uses the population restriction to drop anyone living in a location with more than } 50,000 \text { residents. Columns } 1-2 \text { are restricted } \\
\text { to women living on the farm and renting between the ages of } 16-45 \text {. Columns } 3-4 \text { are restricted to women aged } 16-35 \text {. } \\
\text { Columns 5-6 are restricted to women aged } 30-40 \text {. Standard errors clustered at the state level: }{ }^{* * *} \text { p }<0.01 \text {, }{ }^{* *} \text { p }<0.05 \text {, * } p< \\
0.1\end{array}$} \\
\hline
\end{tabular}




\section{Appendix Table A11 - Labor Force Outcomes and Interactions}

\begin{tabular}{|c|c|c|c|c|c|}
\hline & $\begin{array}{l}\mathrm{Y}=\mathrm{In} \text { labor } \\
\text { force }\{0,1\}\end{array}$ & $\begin{array}{c}\mathrm{Y}=\text { work in } \\
\text { agriculture } \\
\{0,1\} \\
(2)\end{array}$ & $\mathrm{Y}=\mathrm{Ln}$ (births) & $\begin{array}{c}\mathrm{Y}=\text { \# children } \\
\text { under } 5\end{array}$ & $\begin{array}{l}\mathrm{Y}=\text { total } \\
\text { children in } \\
\text { household } \\
\text { (5) }\end{array}$ \\
\hline Ag. Crop Index & & & & & $\begin{array}{l}-0.266^{* * *} \\
(0.0890)\end{array}$ \\
\hline Observations & $21,752,831$ & $21,752,831$ & $28, / 32$ & 16,698, & $11,554,243$ \\
\hline \multicolumn{6}{|c|}{$\begin{array}{l}\text { Notes: Columns 1-2 use the 1900-1930 complete count census data (expanded cohort sample). Column } 2 \text { uses the county-level dataset. } \\
\text { Columns } 3-4 \text { use the 1910-1930 complete count census data (cohort sample). Every regression includes county and year fixed effects. Every } \\
\text { regression includes separate interactions between year fixed effects and baseline county fractions of population in } 1910 \text { who are non-white, } \\
\text { between the ages of } 6 \text { and 14, illiterate, and living in an urban area. The county-level controls also include year fixed effect interactions with } \\
\text { manufacturing output per capita in } 1900 \text {, the fraction of women living on farms in } 1910 \text {, and the sex ratio in } 1910 \text {. Individual controls include } \\
\text { fixed effects for age, race, location population, farm status, birthplace, interactions between the year fixed effects and each of the individual } \\
\text { characteristics, and every two-way interaction between the individual characteristic fixed effects. The population restriction in Column } 3 \\
\text { drops counties in the top } 10 \text { percent of the population in } 1910 \text {; the population restriction in the other columns drops anyone living in a } \\
\text { location with more than } 50,000 \text { residents. The complete count regressions include state-by-year fixed effects. The complete count regressions } \\
\text { are restricted to women living on the farm and renting between the ages of } 16-45 \text {. Columns } 4 \text { is restricted to women aged } 16-35 \text {. Column } 4 \text { is } \\
\text { restricted to women aged } 30-40 \text {. Columns } 1-2 \text { use the current year crop index because the outcome is labor force participation (1 if any } \\
\text { industry is reported, zero otherwise) or working in agriculture (zero otherwise). Columns } 3-5 \text { use the one year lagged index. The crop index } \\
\text { is interacted with an indicator equal to one if the county was above the median in female agricultural labor force participation in } 1900 \text {, zero } \\
\text { otherwise. Standard errors clustered at the state level: } * * * p<0.01, * * p<0.05, * p<0.1\end{array}$} \\
\hline
\end{tabular}




\section{Appendix Table A12 - Marriage Delay}

\begin{tabular}{|c|c|c|c|c|c|c|c|}
\hline $\mathrm{Y}=\operatorname{Married}\{0,1\}$ & (1) & (2) & (3) & (4) & (5) & (6) & (7) \\
\hline Ag. Crop Index & $\begin{array}{c}-0.0001 \\
(0.0009)\end{array}$ & $\begin{array}{c}-0.0007 \\
(0.0006)\end{array}$ & $\begin{array}{c}0.0013 \\
(0.0009)\end{array}$ & $\begin{array}{c}-0.0012^{* *} \\
(0.0005)\end{array}$ & $\begin{array}{c}-0.0016^{* * *} \\
(0.0006)\end{array}$ & $\begin{array}{c}-0.0012 * \\
(0.0006)\end{array}$ & $\begin{array}{c}-0.0019 * * * \\
(0.0005)\end{array}$ \\
\hline Population Restriction & & Y & $\mathrm{Y}$ & $\mathrm{Y}$ & $\mathrm{Y}$ & $\mathrm{Y}$ & $\mathrm{Y}$ \\
\hline Farm Restriction & & & $\mathrm{Y}$ & $\mathrm{Y}$ & $\mathrm{Y}$ & $\mathrm{Y}$ & $\mathrm{Y}$ \\
\hline Controls & & & & $\mathrm{Y}$ & $\mathrm{Y}$ & $\mathrm{Y}$ & $\mathrm{Y}$ \\
\hline Renter Restriction & & & & & $\mathrm{Y}$ & $\mathrm{Y}$ & $\mathrm{Y}$ \\
\hline State $\mathrm{x}$ Year FE & & & & & & $\mathrm{Y}$ & \\
\hline Individual FE & & & & & & & $\mathrm{Y}$ \\
\hline Observations & $249,231,492$ & $151,690,250$ & $50,936,903$ & $50,936,619$ & $25,701,474$ & $25,701,474$ & $25,701,474$ \\
\hline $\begin{array}{l}\text { Notes: Estimated using th } \\
\text { regression includes county } \\
50,000 \text { residents. The farn } \\
\text { Controls include fixed eff } \\
\text { the individual characterist } \\
\text { interactions between the y } \\
\text { at the state level: } * * * p \\
\end{array}$ & $\begin{array}{l}\text { nel spanning } 19 \\
\text { d year fixed eff } \\
\text { striction drops } ~ \\
\text { for age, race, lc } \\
\text { and every two- } \\
\text { fixed effects an } \\
\text {,** p }<0.05, *\end{array}$ & $\begin{array}{l}10-1930 \text { based } \\
\text { cts. The popula } \\
\text { omen not living } \\
\text { cation populatic } \\
\text { vay interaction } \\
\text { d the baseline cc } \\
p<0.1\end{array}$ & $\begin{array}{l}\text { the } 1930 \text { compl } \\
\text { on restriction drc } \\
\text { on farms and the } \\
\text { farm status, bir } \\
\text { tween the indivi } \\
\text { nty characteristi }\end{array}$ & $\begin{array}{l}\text { e count Censu } \\
\text { s women who } \\
\text { enter restrictio } \\
\text { place, interact } \\
\text { ual characteris } \\
\text { described in }\end{array}$ & $\begin{array}{l}\text { data. Restricte } \\
\text { ived in places v } \\
\text { drops women } \\
\text { ons between the } \\
\text { ic fixed effects. } \\
\text { oove (sex ratio, }\end{array}$ & $\begin{array}{l}\text { to women aged } \\
\text { th populations } \\
\text { no own their re } \\
\text { jear fixed effec } \\
\text { he controls als } \\
\text { c.). Standard e }\end{array}$ & $\begin{array}{l}6-45 . \text { Every } \\
\text { eater than } \\
\text { dence. } \\
\text { and each of } \\
\text { include } \\
\text { ors clustered }\end{array}$ \\
\hline
\end{tabular}




\section{Appendix Table A13 - Heterogeneous Impacts by \% Owner Operator}

\begin{tabular}{|c|c|c|c|}
\hline Panel A: Y = $\ln$ (County Births) & (1) & (2) & (3) \\
\hline Ag. Crop Index & $\begin{array}{l}-0.087 \\
(0.075)\end{array}$ & $\begin{array}{l}-0.090 \\
(0.073)\end{array}$ & $\begin{array}{l}-0.059 \\
(0.066)\end{array}$ \\
\hline \% Owner Operated X Index & $\begin{array}{l}-0.044 \\
(0.077)\end{array}$ & $\begin{array}{l}-0.062 \\
(0.073)\end{array}$ & $\begin{array}{l}-0.085 \\
(0.068)\end{array}$ \\
\hline $\begin{array}{l}\text { Population Restriction } \\
\text { Controls }\end{array}$ & & Y & $\begin{array}{l}\mathrm{Y} \\
\mathrm{Y}\end{array}$ \\
\hline Observations & 32,146 & 28,732 & 28,732 \\
\hline Panel B: Y = \# Children Under 5 & (1) & (2) & (3) \\
\hline Average Ag. Crop Index & $\begin{array}{c}-0.039 * * * \\
(0.015)\end{array}$ & $\begin{array}{c}-0.056 * * * \\
(0.015)\end{array}$ & $\begin{array}{c}-0.074 * * * \\
(0.021)\end{array}$ \\
\hline Owner Operated X Index & $\begin{array}{l}0.029 * * \\
(0.013)\end{array}$ & $\begin{array}{c}0.041^{* *} \\
(0.017)\end{array}$ & $\begin{array}{c}0.019 \\
(0.016)\end{array}$ \\
\hline Controls & $\mathrm{Y}$ & $\mathrm{Y}$ & $\mathrm{Y}$ \\
\hline Under age 35 & & $\mathrm{Y}$ & $\mathrm{Y}$ \\
\hline Population Restriction & & & $\mathrm{Y}$ \\
\hline Observations & $48,654,437$ & $25,202,812$ & $17,188,595$ \\
\hline Panel C: Y = \# Children & (1) & $(2)$ & (3) \\
\hline Average Ag. Crop Index & $\begin{array}{c}-0.267 * * * \\
(0.077)\end{array}$ & $\begin{array}{c}-0.296 * * * \\
(0.092)\end{array}$ & $\begin{array}{c}-0.268 * * \\
(0.127)\end{array}$ \\
\hline Owner Operated X Index & $\begin{array}{c}0.160 \\
(0.107)\end{array}$ & $\begin{array}{c}0.162 \\
(0.128)\end{array}$ & $\begin{array}{c}0.043 \\
(0.108)\end{array}$ \\
\hline Controls & $\mathrm{Y}$ & $\mathrm{Y}$ & $\mathrm{Y}$ \\
\hline Aged 30-40 & & $\mathrm{Y}$ & $\mathrm{Y}$ \\
\hline Population Restriction & & & $\mathrm{Y}$ \\
\hline Observations & $48,671,889$ & $17,995,726$ & $11,846,739$ \\
\hline \multicolumn{4}{|c|}{$\begin{array}{l}\text { Notes: Panel A uses the county-level dataset while Panels B-C use the } 1910-1930 \text { complete count data. The percent } \\
\text { owner operated variable is taken from the } 1910 \text { agricultural census and is measured at the county-level. Every } \\
\text { regression includes county and year fixed effects. Panel A controls include separate interactions between year fixed } \\
\text { effects and baseline fractions of population in } 1910 \text { who are non-white, between the ages of } 6 \text { and } 14 \text {, illiterate, and } \\
\text { living in an urban area. The controls include year fixed effect interactions with manufacturing output per capita in } \\
\text { 1900, the fraction of women living on farms in 1910, and the sex ratio in 1910. Panels B and C controls include fixed } \\
\text { effects for age, race, location population, farm status, birthplace, interactions between the year fixed effects and each } \\
\text { of the individual characteristics, and every two-way interaction between the individual characteristic fixed effects. } \\
\text { Panel B and C controls also include interactions between the year fixed effects and the baseline county characteristics } \\
\text { described for Panel A (sex ratio, etc.). For Panel A, the population restriction drops counties in the top } 10 \text { percent of } \\
\text { population in1910. For Panels B and C, the population restriction drops anyone living in an location with more than } \\
50,000 \text { residents. Standard errors clustered at the state level: } * * * p<0.01, * * p<0.05, * p<0.1\end{array}$} \\
\hline
\end{tabular}




\section{Appendix Table A14 - Impact on capital share to labor share ratio}

$\mathrm{Y}=$ capital/labor ratio

\begin{tabular}{lccc|ccc} 
& $(1)$ & $(2)$ & $(3)$ & $(4)$ & $(5)$ & $(6)$ \\
\hline Ag. Crop Index (t) & -0.078 & & & $-0.144^{*}$ & & \\
& $(0.070)$ & & & $(0.081)$ & & \\
& & -0.070 & & & $-0.104^{*}$ & \\
Ag Crop. Index (t-1) & & $(0.044)$ & & & $(0.054)$ & \\
& & & 0.019 & & & 0.013 \\
Average Ag. Crop Index (5-yr) & & & $(0.061)$ & & & $(0.073)$ \\
& & & & & & \\
\end{tabular}

Notes: Analysis using agricultural census data $(1910,1920,1925$, and 1930). $\mathrm{N}=9,726$. In addition to county and year fixed effects, each regression includes the baseline controls and the population restriction. Controls include separate interactions between year fixed effects and baseline fractions of population in 1910 who are non-white, between the ages of 6 and 14, illiterate, and living in an urban area. Controls also include year fixed interactions with manufacturing output per capita in 1900, the fraction of women living on farms in 1910, and the sex ratio in 1910. The population restriction drops the counties which are in the top 10 percent of population in 1910. Columns 4-6 include control for baseline fraction of crops comprised of cotton. Standard errors clustered at the state level: $* * * \mathrm{p}<0.01, * * \mathrm{p}<0.05, * \mathrm{p}<0.1$ 


\section{Appendix Figure A1 - US Fertility and Crude Birth Rate, 1910-1930}

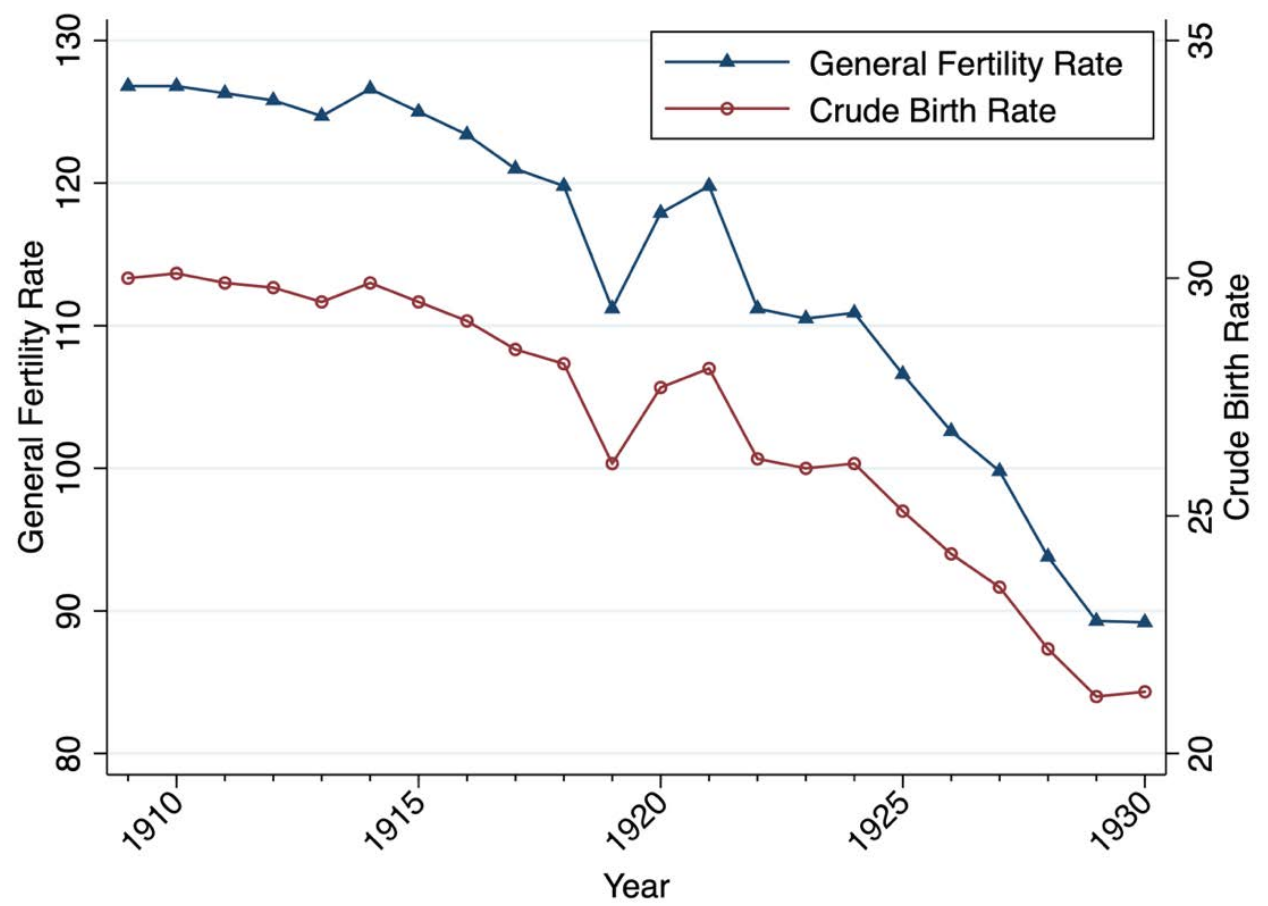

Notes: National Vital Statistics System data (NVSS, 2017). The general fertility rate is the number of births per 1,000 women aged 15-44. The crude birth rate is the number of annual live births per 1,000 people in the country's population.

\section{Appendix Figure A2 - Correlation between 1929 Retail Sales and Agricultural Index}

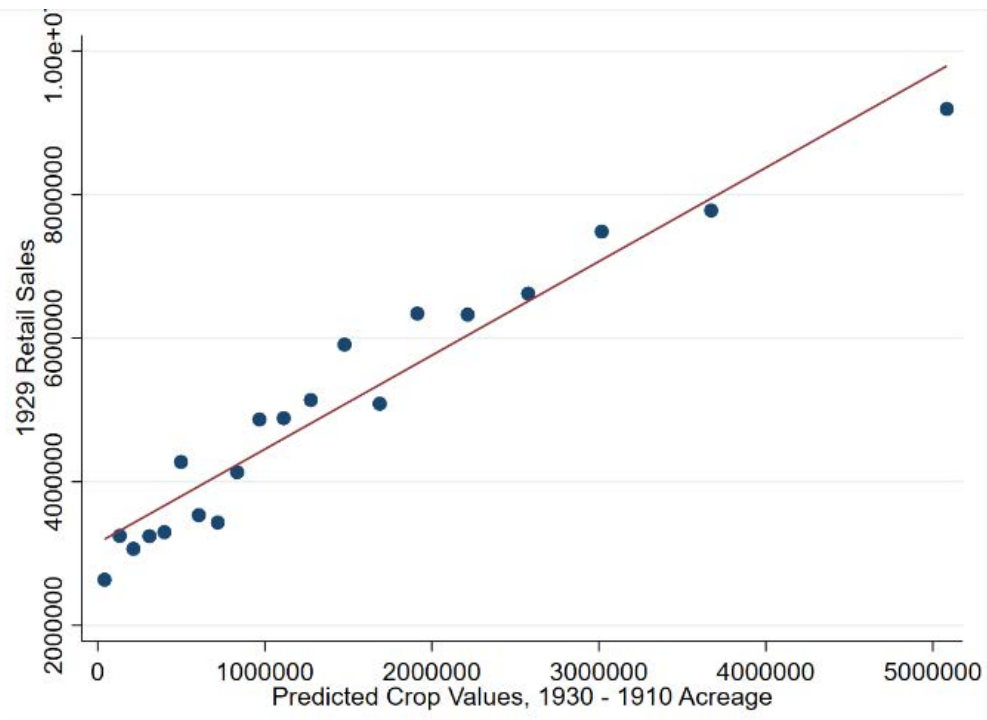

Notes: The figure is a bin-scatter plot of 1929 County-level Retail Sales (y-axis) and 1930 County-level crop index (x-axis). The sample is restricted to include counties with 50,000 or less in population as of 1919. Each dot represents 126 counties. 


\section{Appendix Figure A3 - States in County Birth Sample}

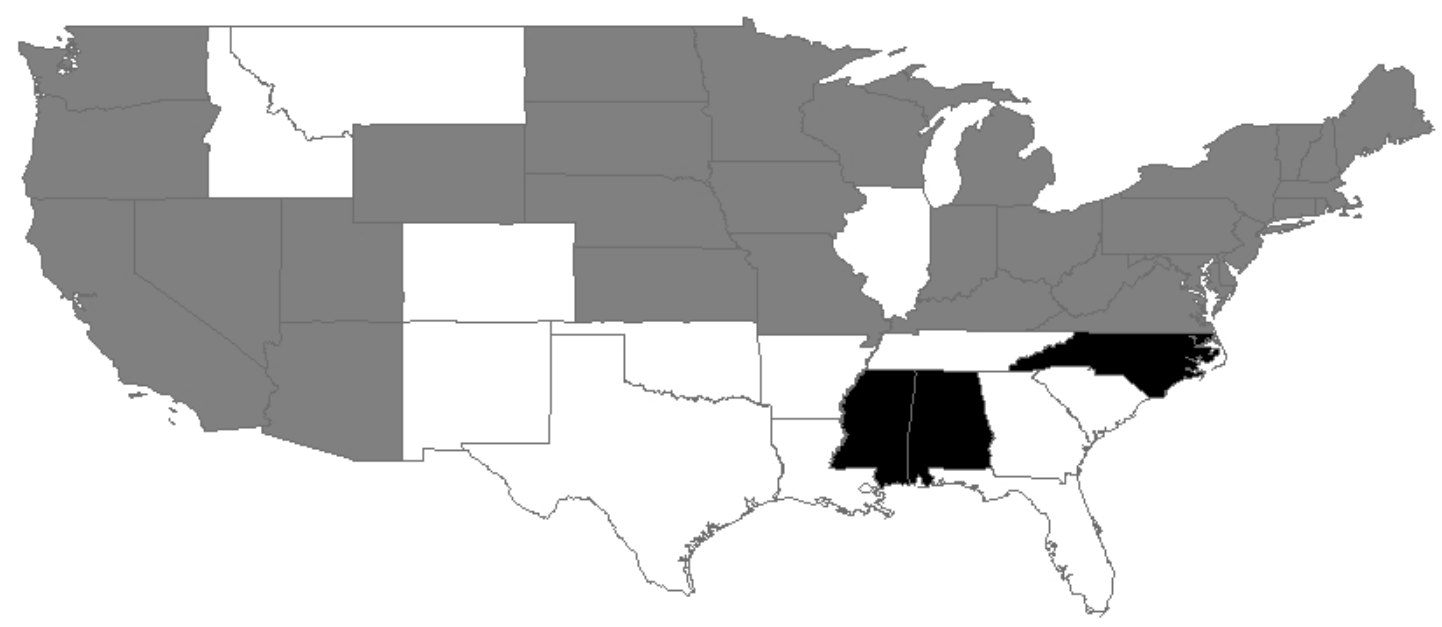

Notes: States shaded in grey appear in our main county-year birth sample, covering the years 1910-1930. States shaded in black appear in a robustness sample where we relax our sample criteria (i.e., missing no more than 2 years of data prior to entry in the BRA). States shaded in white are do not report data early enough to be included.

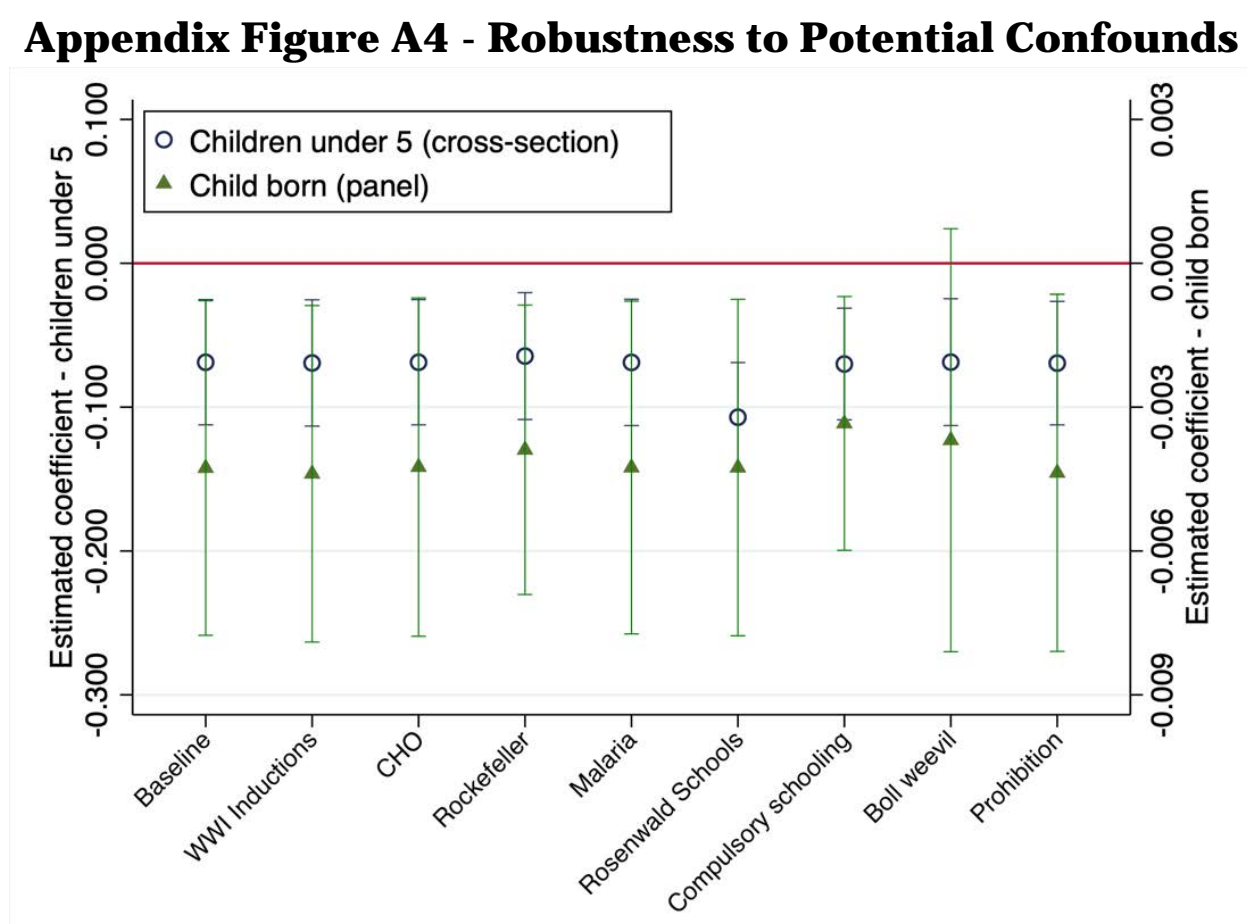

Notes: Coefficients on the one year lagged crop index when using the individual birth history (panel) data and the coefficients on the 5-year average index when using the Census cohort data with the inclusion of different control variables. 95\% confidence intervals based on state-level clustering shown. 


\section{Appendix Figure A5 - County-Level Excess Mortality 1918-1920, Spanish Influenza}

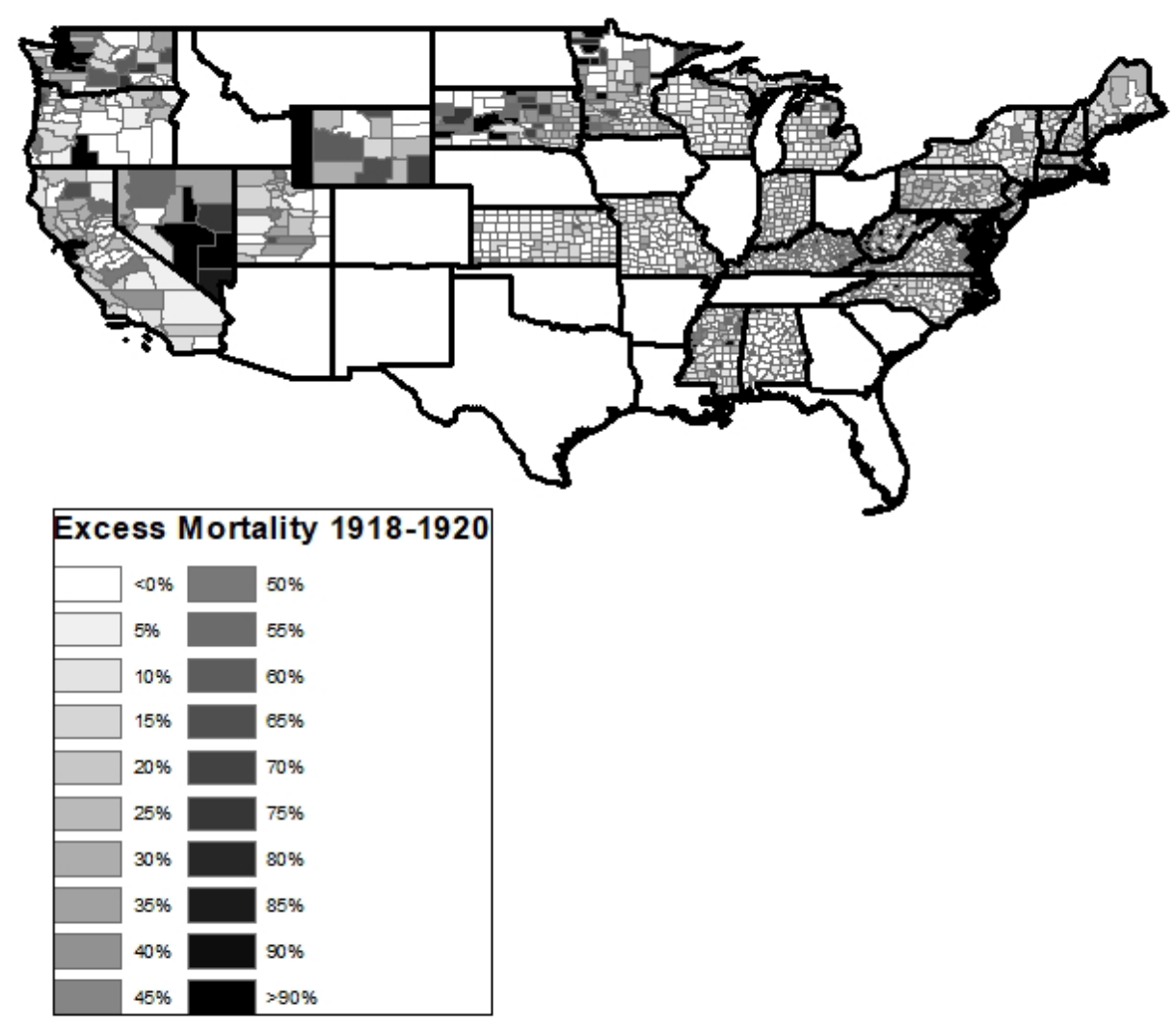

Notes: We follow Beach, et al. (forthcoming) to construct the excess mortality from trend 1918-1920 to capture the local intensity of the Spanish Influenza. The underlying mortality data is drawn from a combination of newly digitized all-cause mortality death county level counts from various state health reports in 25 states and Eriksson, Niemesh, and Thomasson (2018). 


\section{Appendix Figure A6 - 1937 Malaria Mortality}

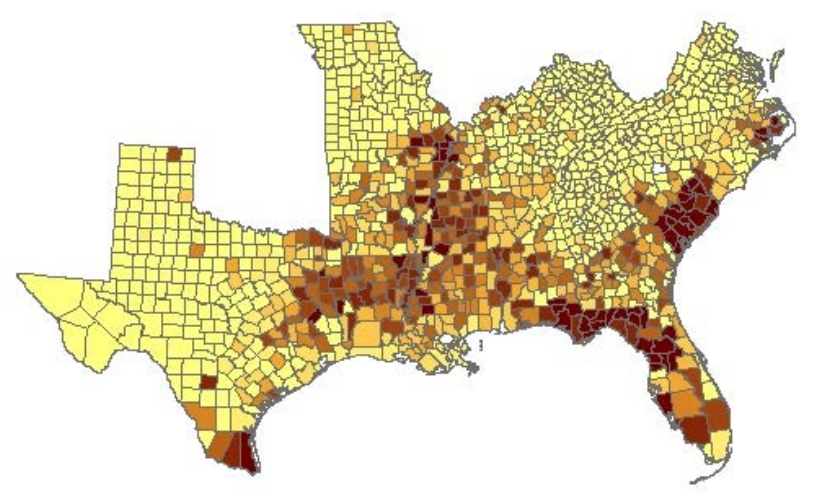

Malaria Death Rate per $\mathbf{1 0 0 , 0 0 0}$

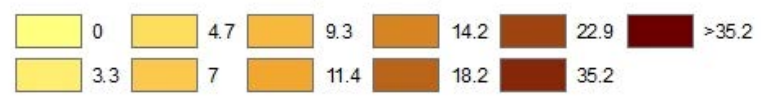

Notes: 1937 Malaria mortality at the county level for the state report sample. Data from state health reports and state vital statistics.

\section{Appendix Figure A7 - Correlation between food prices and agricultural index}

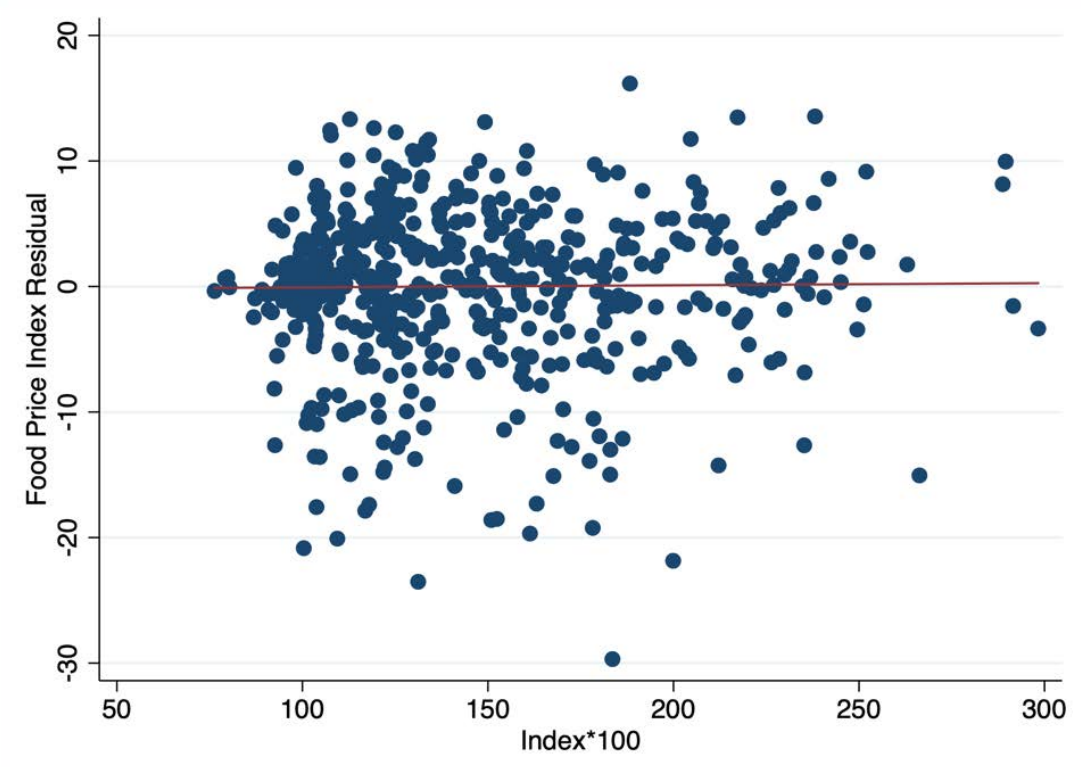

Notes: The Bureau of Labor Statistiscs (BLS) Consumer Price Index (CPI) City-level food price index residuals for 1913-1928, netting out year and city fixed effects, plotted against the agricultural crop price index (multiplied by 100). 


\section{Appendix Exhibit A1 - Female Wage in California, The Californian 1918}

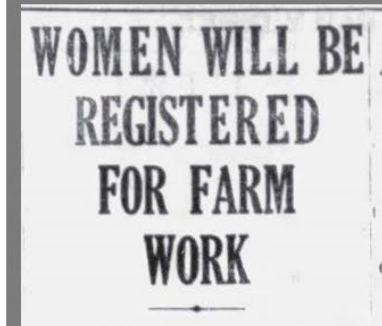

Task Will Be Accomplished By Women's Land Army of America

JOBS FOR THE JOBLESS

Organization Demands "Going Wages" For All the Workers Sent Out

All able-bodied women over 18 years of age who will be available for farm work in 1919 are to be registered in northern California during the coming winter, if plans made at a conference of the county chairman and advisory board of the women's land army of America, northern California distriet, are realized.

The women's land army is ready to till all demands for women workers for farms, packing houses and canneries this season, it was announced after the conference. Mrs. Katherine P. Edson, member of the land army's advisory board and ex ecutive officer of the state indus'trial welfare commission, said that standards of wages, housing and hours had been fixed and that no disturbance of labor conditions would result from the employment of women.

The "going wage" is demanded for the women workers sent out by the army, said Mrs. Edson, and their services will be offered in wage dispute cases only when male workers refuse the awards of United States mediators.

Mrs. Sydney Joseph of Berkeley. chairman, explained that, while a $\$ 2$ minimum is fixed for women's land army corps workers, they must

be given the wage commonly paid male workers. Other regulations an-

pounced include: A standard eighthour day, overtime not to exceed I wo hour at the rate of one and a quarter times the regular wage, and living conditions conforming to the state housing and immigration commission's standards.

Methods for registering women to assist in harvesting 1919 crops will be determined at later conferences, it was announced. 
Appendix Exhibit A2 - Prevailing Agricultural Wages, Baltimore Sun 1919 HIGHEST FARM WAGES IN HALF CENTURY PAID IN 1918

WAGES for farm labor in the United States, as State-group averages. A ree States have more than doubled ord of 53 years of farm wages places since 1902 and have increased 43 to 641918 at the top, and far above the highper cent, for the different classes of hir- est rates of the half century before 1916. ing since 1916, or 53 per cent. for farm Wage earnings measured by purchasing labor in general. These comparisons power may warrant a different stateare warranted by the results of a re- ment.

ent investigation made by the Bureau While the wages of farm labor have of Crop Estimates, United States Department of Agriculture.

For 1918 the wage rate per month with board was $\$ 34.92$, without board 37.07: per day in barvest with board $\$ 2.65$, without board $\$ 3.22$; per day out of harvest with board $\$ 2.07$, without board \$2.63. These are averages fo the United States. The highest rates were in the far West, and next below are those of the west North Central are those of the west North Central month wages with board, Wages by
States. The wage rates of the South
Atlantie States were lowest and were for work outside of harvest have
Atlane Atlantie States were lowest and were advanced more strongly than for harvest
a little below those of the South Central work. Apparently the procurement of

greatly inereased in only two years and have doubled in 16 years, it is interesting to observe that from the time of low-water mark in farm wages, 25 years 1893-1897, the rates have increased from 165 to 229 per cent, for the different lasses of hirings.

Day wages on farms increased in reater degree than month wages did during the last two years, and this is true for the last 16 years, except for athe below those of the South Central work. Apparently the procurement of 


\section{Appendix Exhibit A3 - Women's Land Army poster}

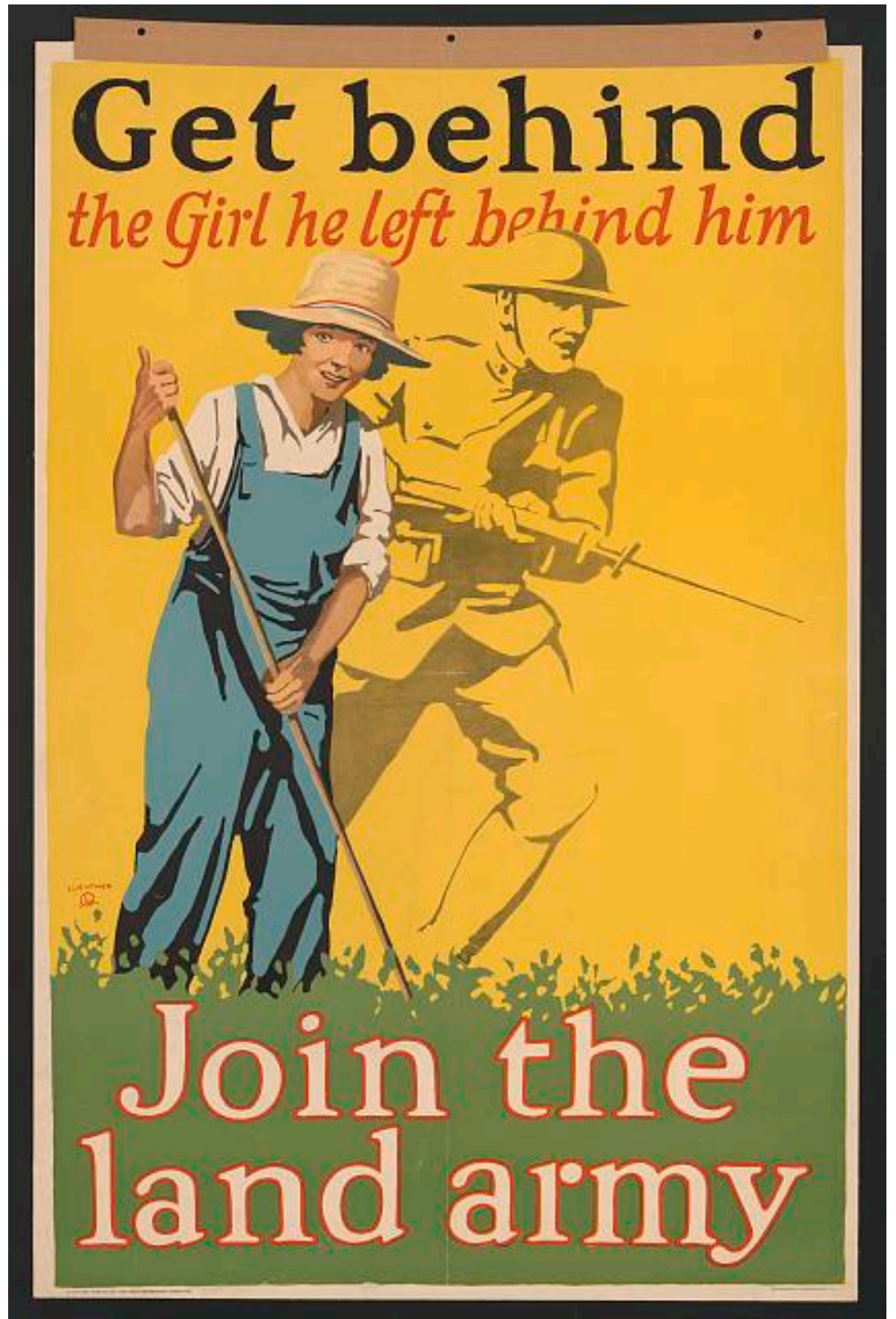

Source: https:// blogs.loc.gov/loc/ 2018/ 03/ world-war-i-the-womens-land-army/ 
Appendix Exhibit A4 - Women's Land Army poster, New J ersey

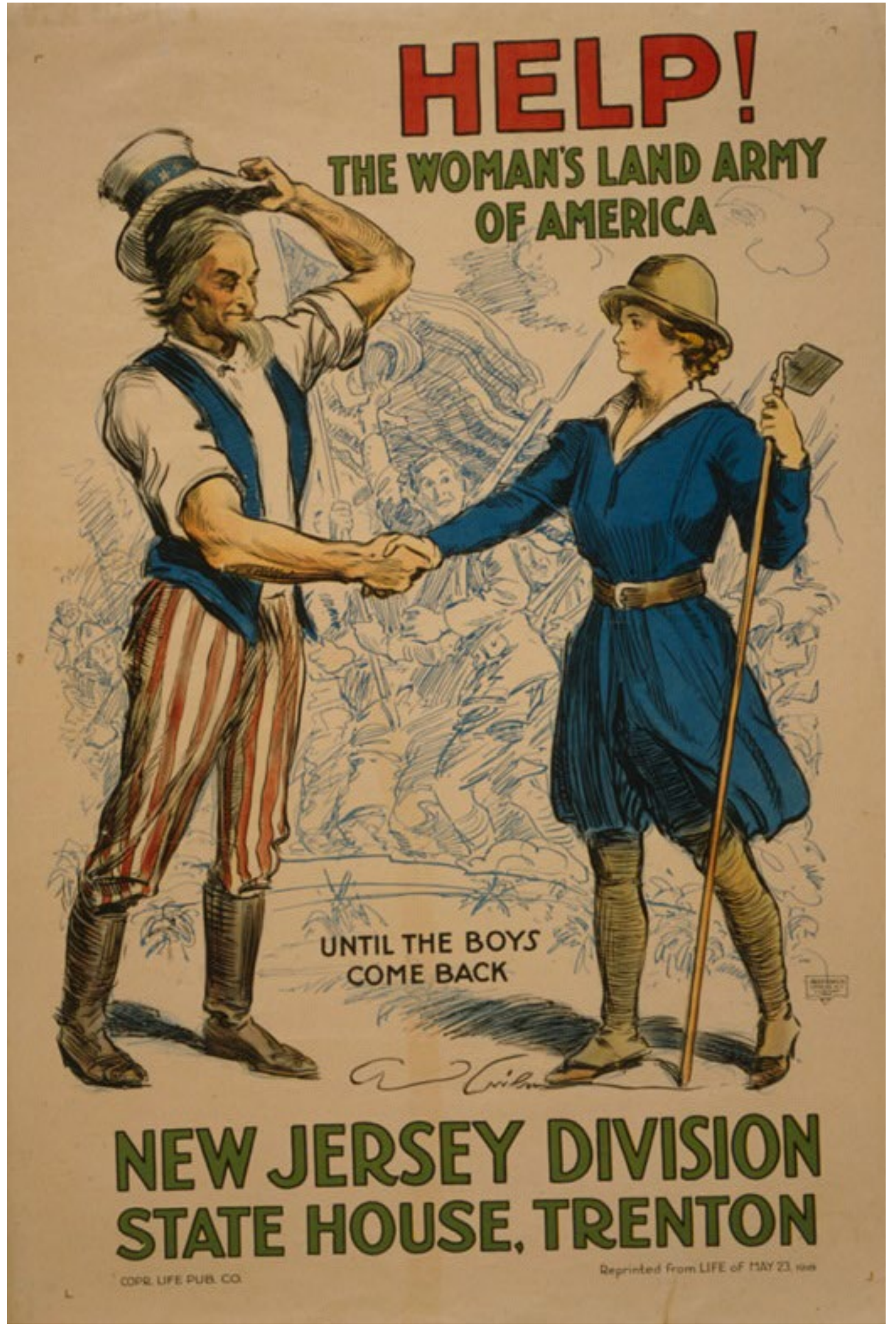




\section{Appendix Exhibit A5 - Women's Land Army poster - plow}

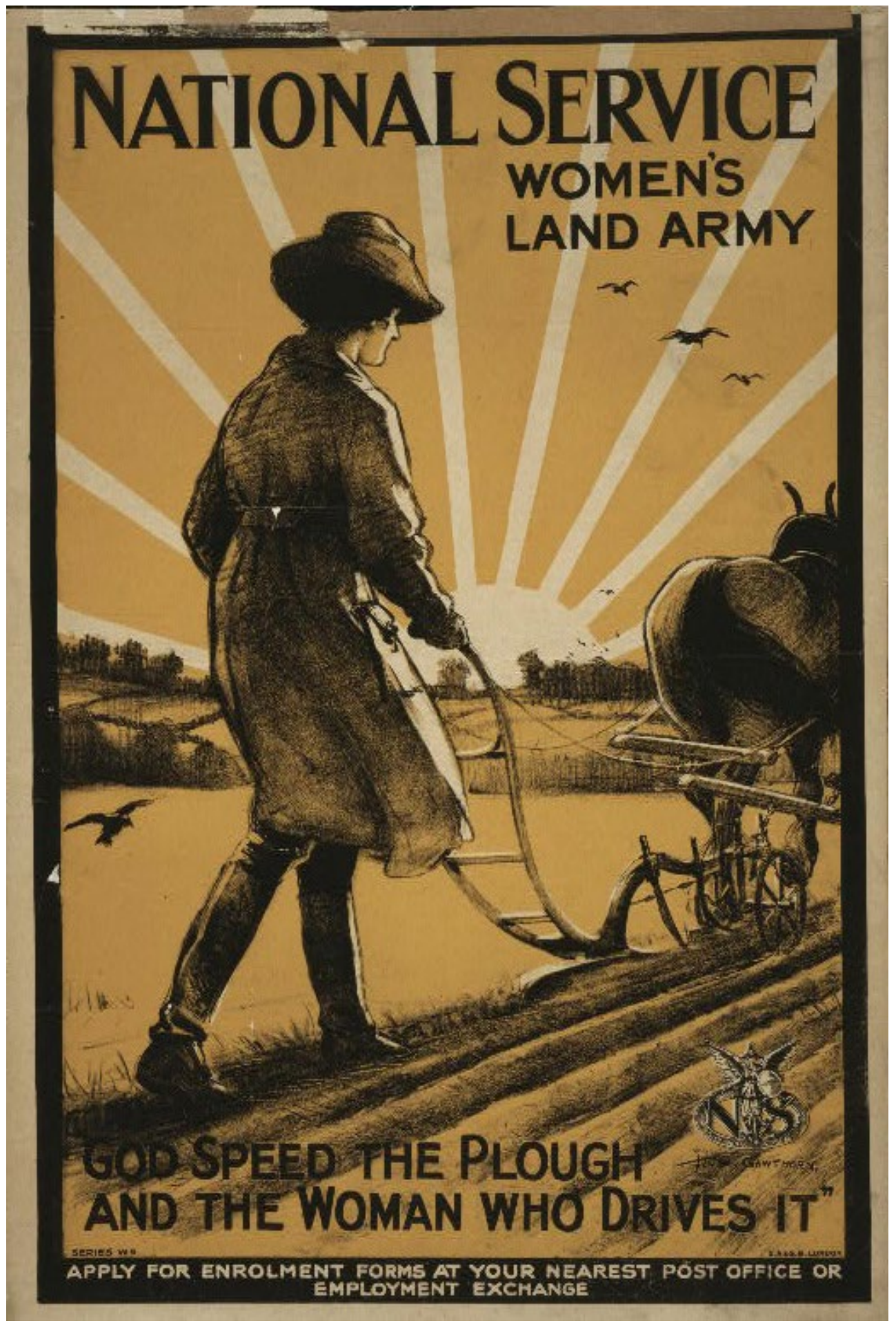

Source: https:/ / www.kcet.org/ history-society/ the-womens-land-army-farmettes-for-suffrage-duringworld-war-i 


\section{Appendix Exhibit A6 - Malaria control map}

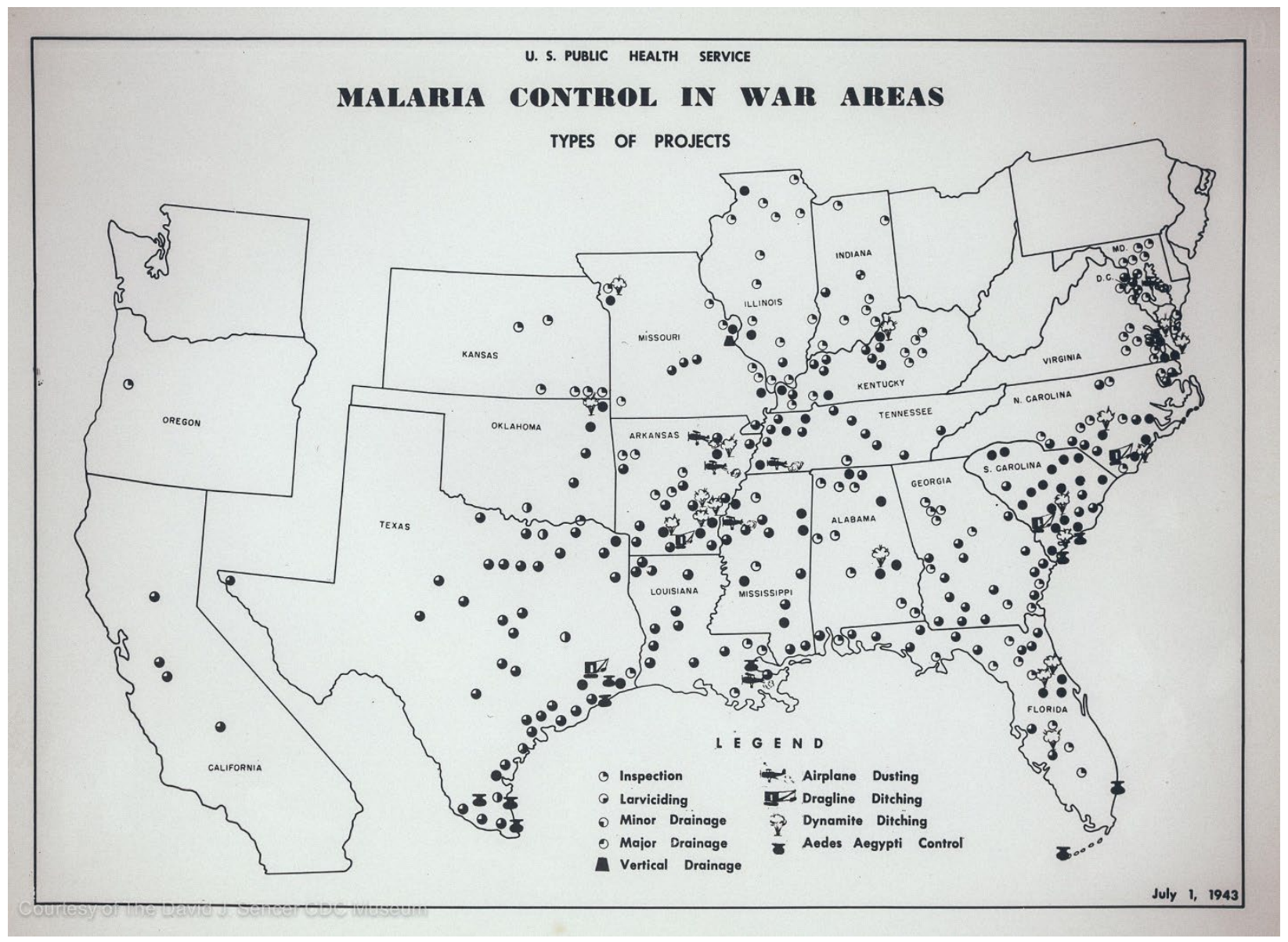




\section{Appendix B: Agricultural Suitability Price Index IV}

In our baseline model we define the agricultural Crop Index as follows following work by Rajan and Ramcharan (2015) and J aremski and Wheelock (forthcoming):

$$
\text { CropIndex }_{c, t}=\frac{\sum_{i=1}^{12} Q_{i, c, 1910} \times P_{i, t}}{\sum_{i=1}^{12} Q_{i, c, 1910} \times \bar{P}_{l}}
$$

One concern with this formulation is that the underlying crop shares, $Q_{i, c, 1910}$, may not be exogenous. For instance, the share may jointly be determined with fertility. An example from the literature comes from Alesina and Nunn (2013), who highlight the role that the plow played in the development of gender roles. To address this concern, we follow Fiszbein (forthcoming), and estimate predicted shares based on measures of crop suitability by the FAO-GAEZ. Climate experts using data from the second half of the 20th Century developed the FAO-GAEZ measures, ignoring actual crop production patterns. Nunn and Qian (2011) describe the FAO-GAEZ data construction process in detail and highlight the correlation of the FAO-GAEZ measures and historic cultivation patterns.

The FAO-GAEZ's reports predict crop yields under a variety of different climate models and assumed level of inputs at the $0.5 \times 0.5$ degree grid cell size. For our purposes, we use the predicted yields in each county, $A_{c}$, for 13 crops (corn, wheat, oats, barley, rye, buckwheat, flaxseed, cotton, tobacco, Irish potatoes, sweet potatoes, alfalfa, and pasture grass) assuming a medium level of inputs and rain fed irrigation. We compute the average predicted yield in each county using 1910 county boundaries. We then combine these data with the observed share of acreage for 11 crops, $\theta_{i c}$, (corn, wheat, oats, barley, rye, buckwheat, cotton, tobacco, Irish potatoes, sweet potatoes, and forage crops), such that $\sum_{i} \theta_{i c}=1$, to estimate the fractional multinomial logit. ${ }^{29}$ These shares are based on the reported number of acres planted in each crop from the 1910 Census of Agriculture. We specify the fractional multinomial logit model as follows:

$$
\hat{\theta}_{i c}=E\left[\theta_{i c} \mid A_{c}\right]=\frac{e^{\beta_{i}^{\prime} A_{c}}}{1+\sum_{j=1}^{I-1} e^{\beta_{j}^{\prime} A_{c}}} .
$$

We estimate the model using quasi-maximum likelihood. By construction, $\sum_{i} \hat{\theta}_{i c}=1$. As Fiszbein (forthcoming) points out, the estimation framework is consistent with a profit maximization model. We use the predicted shares, $\hat{\theta}_{i c}$, to construct our predicted crop index. Because our predicted index relies on predicted acreage rather than crop output, we construct our predicted index as follows:

First, we compute the predicted acreage planted in each crop using the 1910 Census value of improved acreage and the predicted share:

29 We omit the inclusion of flaxseed acreage from the fractional multinomial logit because it is highly collinear with other crop suitability measures and is planted in less than 10 percent of counties. 


$$
\hat{\gamma}_{i c}=\hat{\theta}_{i c} \times \text { Improved Acres }_{c, 1910} .
$$

We then compute the average output per acre of each crop, $\mu_{i}$, conditional on having positive acreage, using data from the 1910 Census of Agriculture. Finally, we construct the index as follows:

$$
\text { PredictedCropIndex } x_{c, t}=\frac{\sum_{i=1}^{11} \widehat{\gamma}_{i c} \times \mu_{i} \times P_{i, t}}{\sum_{i=1}^{11} \widehat{\gamma}_{i c} \times \mu_{i} \times \bar{P}_{l}}
$$

In Appendix Figure B1 we highlight how the PredictedCropIndex $x_{c, t}$ varies over time and space, and compare the predicted index to the actual index.

We present the results of this IV approach in Appendix Table B1. As in the main text, all estimates report standard errors clustered at the state level. The first column shows our preferred baseline results from Column 3 of Table 1 for comparison. The second column shows that the climate-based instrument is a strong predictor of the of the crop index we use throughout the paper. The final column shows the second stage results of this IV framework. The point estimate in the third column is nearly twice the size of the coefficient from the first column, yet this result is generated from a weak instrument. To summarize, this exercise helps address concerns about our Bartik-style index and supports our (more conservative) main findings.

\begin{tabular}{|c|c|c|c|}
\hline Dependent variable: & $\begin{array}{c}\text { (1) } \\
\text { ln(births) } \\
\text { Baseline }\end{array}$ & $\begin{array}{c}(2) \\
\text { Ag. Crop Index } \\
1^{\text {st }} \text { Stage }\end{array}$ & $\begin{array}{c}(3) \\
\ln \text { (births) } \\
2^{\text {nd }} \text { Stage }\end{array}$ \\
\hline Ag. Crop Index & $\begin{array}{c}-0.112 * * \\
(0.049)\end{array}$ & & $\begin{array}{c}-0.247^{*} \\
(0.124)\end{array}$ \\
\hline Predicted Ag. Crop Index & & $\begin{array}{c}0.226^{* * *} \\
(0.061)\end{array}$ & \\
\hline F-statistic & & & 13.57 \\
\hline Observations & 28,732 & 28,607 & 28,607 \\
\hline \multicolumn{4}{|c|}{$\begin{array}{l}\text { Notes: Column } 1 \text { replicates the result from Table } 1 \text {, Column } 3 \text {. Using the county-level birth records, each } \\
\text { regression includes county fixed effects and year fixed effects, as well as separate interactions between } \\
\text { year fixed effects and baseline fractions of the population in } 1910 \text { who are non-white, between the ages } \\
\text { of } 6 \text { and } 14 \text {, illiterate, and living in an urban area. The controls also include year fixed effect interactions } \\
\text { with manufacturing output per capita in } 1900 \text {, the fraction of women living on farms in } 1910 \text {, and the sex } \\
\text { ratio in } 1910 \text {. The population restriction drops the counties which are in the top } 10 \text { percent of the } \\
\text { population in } 1910 \text {. Column } 2 \text { shows the first stage result when we instrument the crop price index using } \\
\text { measures of crop suitability from the United Nation's Food and Agriculture Organizations Global Agro- } \\
\text { Ecological Zones (FAO-GAEZ) and the method detailed in Fiszbein (forthcoming). Standard errors } \\
\text { clustered at the state level: } * * * p<0.01, * * p<0.05, * p<0.1\end{array}$} \\
\hline
\end{tabular}

Appendix Table B1 - Instrumental variable results 
Appendix Figure B1 - Spatial-Temporal Variation in Predicted and Observed Index

Panel A: Predicted Index
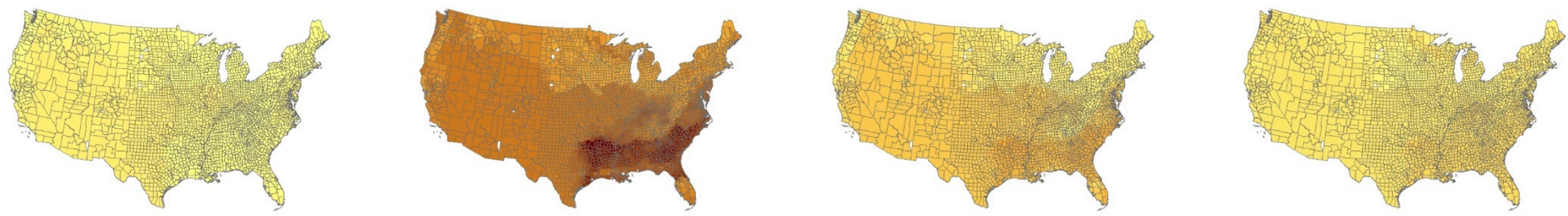

Panel B: Crop Index

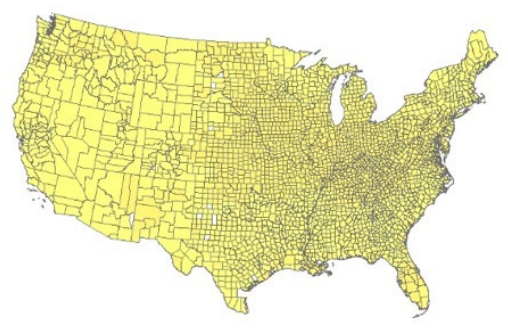

(a) 1914

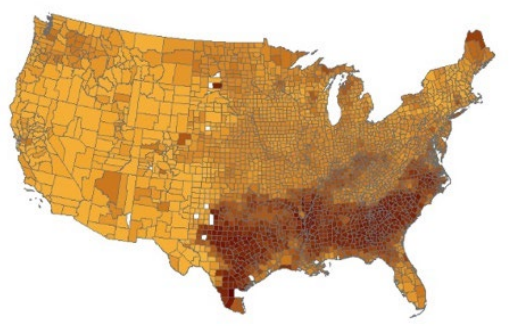

(b) 1919

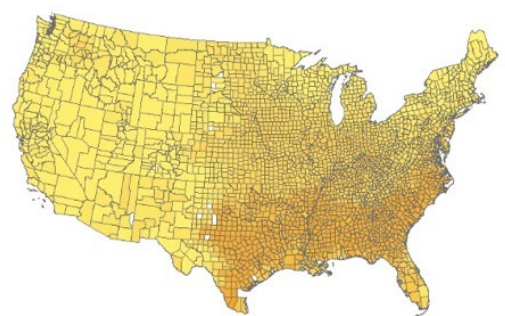

(c) 1924

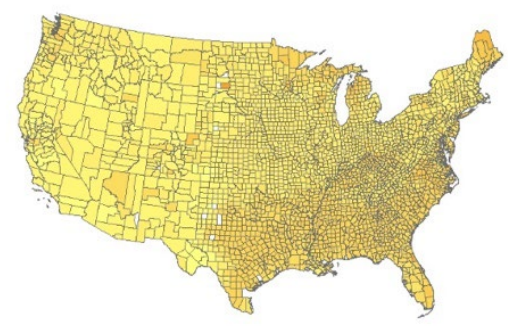

(d) 1929

Agricultural Index Value

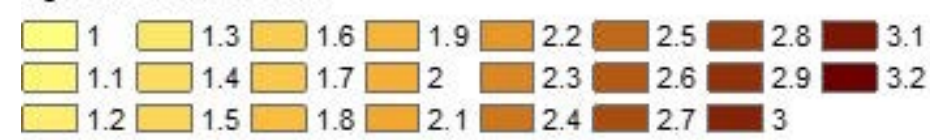




\section{Appendix C: Description of Robustness Data}

In this appendix, we describe the different datasets collected to test the robustness of our main estimates to potential confounds.

WWI Draft Data

The United States drafted over 4 million men during WWI. Therefore, our estimates could be the result of fewer available partners and not due to the agricultural boom/ bust. Further, local draft boards had significant discretion in the administration of deferments, which could be given on the basis of occupation. Thus, it is possible that the agricultural boom and draft are correlated with one another. To limit the impact of the draft on our estimates, we have collected and coded the Final Report of the Provost Marshal General (1920), which reports the number of men drafted in each draft precinct (smaller than counties). We aggregate the WWI precinct-level draft numbers to the county-level and directly control for the number of men inducted.

Spanish Flu Data

To address the potential impact of Spanish Influenza we include a measure of county-level exposure. To construct the Spanish Flu exposure measure we return to the state health reports and county-level vital statistics (Eriksson, Niemish, and Thomasson, 2018) to construct an annual county-level panel of all-cause mortality. The growing literature that assesses the impacts of the Spanish Flu in the United States (Almond and Mazumder, 2005; Almond, 2006; Clay, Lewis, and Severnini, 2018; Corriera, Luck, and Verner, 2020; and Beach, et al., forthcoming) has thus far relied on either a cohort exposure design or a measure of excess mortality derived from a sample of cities in the Census Death Registration Area. Our all-cause mortality sample enables us to construct a measure of excess county-level deaths with much greater geographic coverage (as described in Beach et al., forthcoming). We then interact the excess mortality measure with year fixed effects for counties in 31 states for which we were able to collect 
mortality statistics. The county-level mortality sample is new to the literature. ${ }^{30} \mathrm{We}$ highlight the spatial variation in excess deaths in Appendix Figure A5.

County Health Organization Data:

Following the end of WWI and the subsequent expansion of the franchise to women, federal funds flowed to states via Sheppard-Towner to fund women and infant care. With few exceptions, states accepted the federal funds (Moehling and Thomasson, 2012). Often time these funds were funneled through the states' recently formed or expanded State Health Departments. As a result of the expanded public dollars, as well as privately funded public health efforts that were underway, there was a rapid rollout of County Health Offices ( $\mathrm{CHO}$ ) that administered a variety of preventative care measures, educated the public, invested in clean water, and treated communicable disease. HoehnVelasco $(2018,2019)$ documents that the rollout of CHOs reduced infant mortality and increased later life earnings for treated boys. Ideally, we would be able to directly control for infant mortality; however, the data are not consistently reported in the preBRA period. We estimate a set of regressions controlling for the opening of a $\mathrm{CHO}$ at the county level using the data from Hoehn-Velasco (2019). ${ }^{31}$

Rockefeller Sanitary Commission Data:

Outside of the public sector, there were also major private interventions led by the Rockefeller Sanitary Commission (RSC) that began before the breakout of WWI. In the South in particular, the RSC provided funding and human resources to aid in two eradication campaigns, first hookworm, and then malaria. Bleakley $(2007,2010)$ and Bleakley and Lange (2009) study how the RSC campaigns affect the returns to schooling and changes in fertility. We have collected and re-coded the RSF hookworm campaign data at the county level and include measures of the pre-eradication hookworm infection rate, and interact that measure with year fixed effects.

\footnotetext{
30 We restrict the sample to states with at least two years of county-level mortality data before 1918, necessitating the omission of Arizona, Iowa, North Dakota, Nebraska, and Ohio. We include Alabama, Mississippi, and North Carolina in our complete count regressions. Additionally, we also correct the Eriksson, Niemish, and Thomasson (2018) death counts for New York City.

${ }^{31}$ These data originally are reported in Ferrell (1932).
} 


\section{Malaria Eradication Data}

To address the potential impact of malaria eradication, we have collected county-level malaria mortality data from a combination of state health reports and state vital statistics reports in 1937. One drawback of measuring malaria intensity in 1937 is that public health efforts ramped up in the early 1930s (Kitchens, 2013), however, our measure occurs before the arrival of DDT and subsequent eradication. The key benefit of measuring malaria in 1937 is that it varies at the county-level, whereas prior work has relied on either state-level measures of malaria (Bleakley, 2010) or imputed data relying on variation in climatic variables when relatively few weather stations existed (Hong, 2007, 2011,2013), which are highly collinear with specifications that include a variety of fixed effects. In Appendix Figure A6, we highlight the spatial variation in malaria and note that our coverage is highly correlated with the implementation of the Malaria Control in War Areas program (precursor to the CDC, see Appendix) ${ }^{32}$ and the USPHS's DDT residual spraying program carried out in the post-WWII era (Centers for Disease Control, 1948).

Compulsory Schooling Data:

During the period we study many states changed compulsory education laws. To address any potential changes in the returns to children as educational opportunities change, we include Goldin and Katz's (2008) measure of compulsory schooling. In addition to changes in compulsory schooling laws that varied at the state-year level, there were also targeted interventions that vary at the county-year level.

Rosenwald School Data:

One notable example is the creation of Rosenwald Schools which targeted blacks in the South. There is evidence that these schools improved educational attainment for blacks (Aaronson and Mazumder, 2011) and subsequently impacted fertility and long-run mortality (Aaronson, Lange, and Mazumder, 2014; Aaronson, Mazumder, Sanders, and 32 https:// history.amedd.army.mil/booksdocs/wwii/Malaria/maps/map04.jpg 
Taylor, 2017). To ensure that our results are not driven by changes in the returns to education in the South via Rosenwald Schools, we directly control for their presence. Boll Weevil Data:

In the South, the Boll Weevil pest entered the United States in 1892 and spread across the South until 1922 (Lange, Olmstead, and Rhode, 2009) inflicting damage to the cotton crop. As a result, recent literature has documented how the Boll Weevil led to changes in fertility (Ager, Herz, and Brueckner, forthcoming), shaped tenancy and marriage patterns (Ager, Brueckner, and Herz, 2017; Bloome, Feigenbaum, and Muller, 2017), increased educational attainment (Baker, 2015; Baker, Blanchette, and Eriksson, 2020), and altered political institutions (Feigenbaum, Mazumder, and Smith, 2020). Given the transformative nature of the Boll Weevil, we add controls for the presence of the pest at its peak in 1922, drawing on data from Bloome, Feigenbaum, and Muller (2017). Specifically, we add controls for the share of a county's land area infested and interact the measure with year fixed effects.

Prohibition Data:

Finally, throughout the 1910s there were major shifts in the attitudes toward alcohol. Many states and cities enacted Prohibition laws, and ultimately, alcohol was prohibited in all counties following the ratification of the $18^{\text {th }}$ Amendment in 1919. Prohibition may directly affect the agricultural crop index, as grains are a primary input to both beer and distilled spirits (Kirkpatrick and Tough, 1932). Prohibition may have also directly affected fertility either due to changes in risky behavior or fetal health conditions. To address potential concerns that time-varying Prohibition policy affects our estimates, we have collected and coded the Anti-Saloon League's Yearbooks from 1910-1920. We follow Jacks, Pendakur, and Shigeoka (2020) and include an indicator variable equal to one if both the county and all cities within the county are dry. 


\section{Appendix D: Correlation between births reported in State Health Reports and births in Censuses with and without NYC Correction}

Eriksson, Niemesh, and Thomasson (2018) point out that even after states entered the BRA, there are discrepancies between the US Population Census and the BRA birth counts. They also document that the most severe discrepancies occur in the South, which is largely missing from our sample. To examine the quality of reporting in our sample, we aggregate the county-year observations to the state-year level and correlate the state-year totals to the state-birth cohort totals from the 1920 and 1930 complete counts of the population Census. In Appendix Figure D1, Panel A, we highlight the correlation between the state health report sample (x-axis) and the 1920 complete count Census (y-axis). The correlation between these two data sources is 0.992 .

Similarly, in Appendix Figure D1, Panel B, we highlight the correlation between the state health report data and the 1930 Census. In 1930, the correlation is 0.994. ${ }^{33}$

\footnotetext{
33 These data reflect a correction made to the Eriksson, Niemesh, and Thomasson (2018) data. In the original data, the birth counts for New York City are underreported by an order of magnitude. We have corrected these drawing on data from Fifty-First Annual Report of the State Department of Health for the Year Ending December 31, 1930: Volume 2 Division of Vital Statistics. Burland Printing Co. New York. 1931. In Appendix Figure D1, we highlight how this correction affects the correlation.
} 


\section{Appendix Figure D1 - Correlation of births between State Health Reports and Complete Count Census}

\section{Panel A: Correlation without NYC Correction}

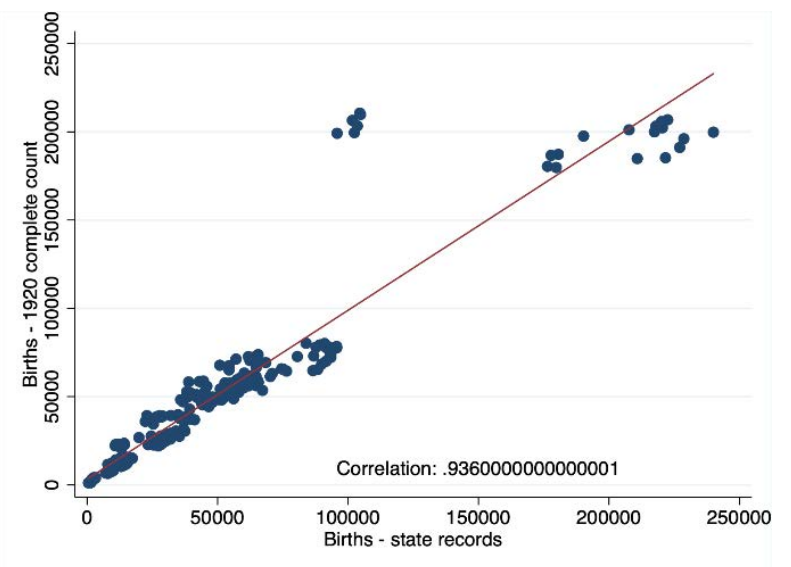

(a) 1920

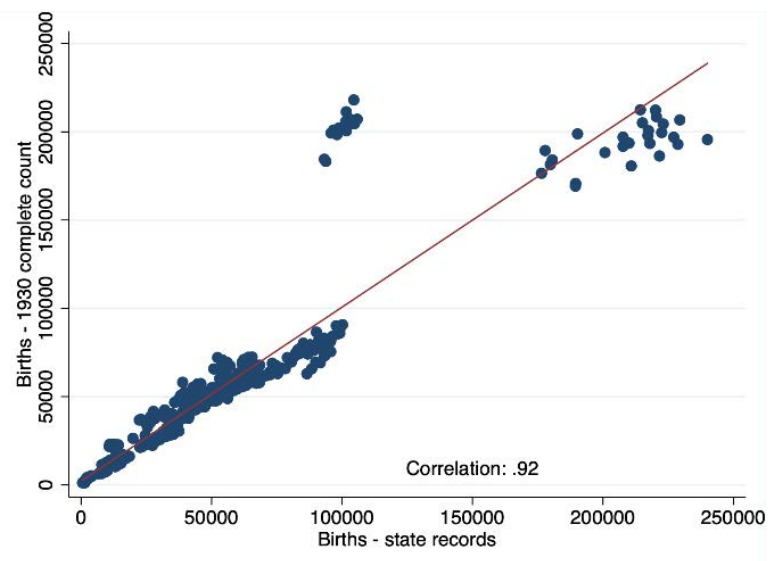

(b) 1930

\section{Panel B: Correlation with NYC Correction}

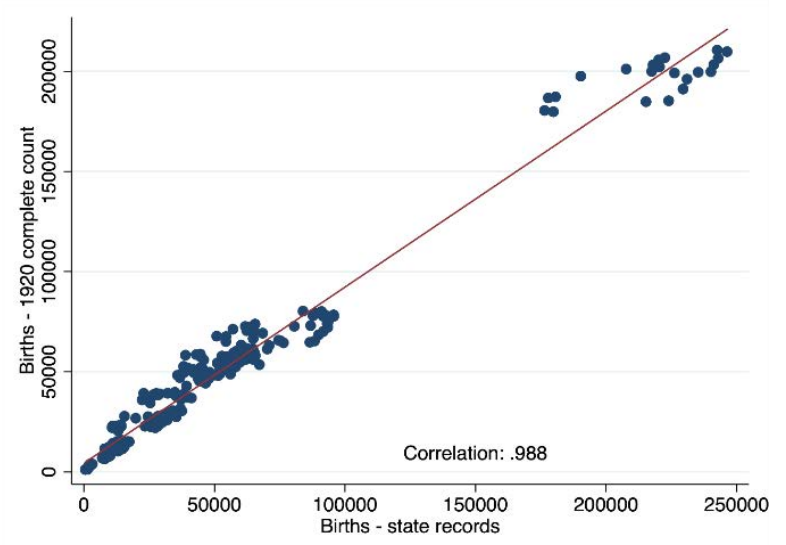

(a) 1920

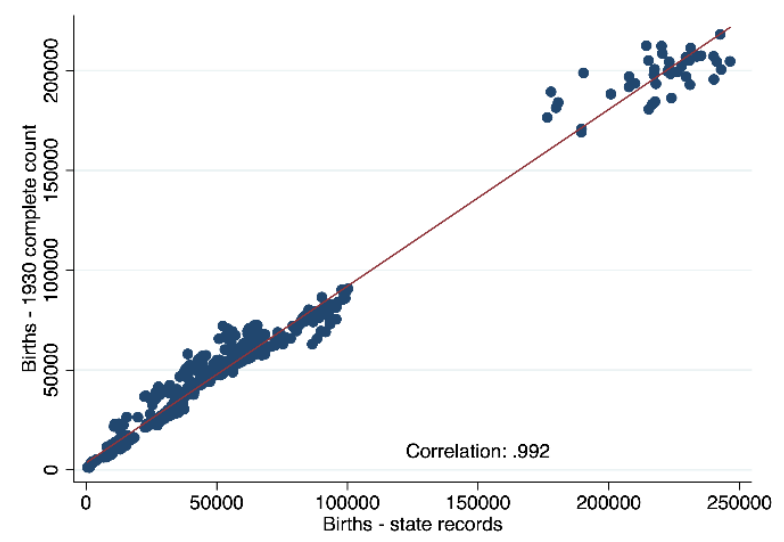

(b) 1930

Notes: Newly digitized birth counts from state health reports compared to complete count census data. The New York City correction accounts for changes in how the populations of NYC boroughs were recorded across the different datasets. The results are similar with or without this correction. 